\title{
\begin{tabular}{l|l} 
Mitraries & DSpace@MIT
\end{tabular}
}

\author{
MIT Open Access Articles
}

\section{Origins of Major Element, Trace Element, and Isotope Garnet Signatures in Mid\#Ocean Ridge Basalts}

The MIT Faculty has made this article openly available. Please share how this access benefits you. Your story matters.

Citation: Krein, Stephanie Brown et al. "Origins of Major Element, Trace Element, and Isotope Garnet Signatures in Mid\#Ocean Ridge Basalts." Journal of Geophysical Research: Solid Earth 125, 12 (December 2020): e2020JB019612. (C2020. American Geophysical Union

As Published: http://dx.doi.org/10.1029/2020jb019612

Publisher: American Geophysical Union (AGU)

Persistent URL: https://hdl.handle.net/1721.1/132676

Version: Final published version: final published article, as it appeared in a journal, conference proceedings, or other formally published context

Terms of Use: Article is made available in accordance with the publisher's policy and may be subject to US copyright law. Please refer to the publisher's site for terms of use. 


\section{JGR Solid Earth}

\section{RESEARCH ARTICLE 10.1029/2020JB019612 \\ Origins of Major Element, Trace Element, and Isotope Garnet Signatures in Mid-Ocean Ridge Basalts}

Key Points:

- The major element composition of garnet peridotite melts provides critical evidence for identifying garnet signatures in MORBs

- Garnet signatures in MORBs are diverse and reflect melting of compositionally and thermally variable mantle without garnet

- Shallow melting of plagioclase peridotite can explain MORB major and trace elements and U-series isotopes with mantle porosity $\phi \geq 1 \%$

Supporting Information:

- Supporting Information S1

Correspondence to:

S. B. Krein,

brownsm@mit.edu

Citation:

Krein, S. B., Behn, M. D., \& Grove, T. L. (2020). Origins of major element, trace element, and isotope garnet signatures in mid-ocean ridge basalts. Journal of Geophysical Research: Solid Earth, 125 , e2020JB019612. https://doi.org/

10.1029/2020JB019612

Received 21 FEB 2020

Accepted 26 OCT 2020

Accepted article online 30 OCT 2020

(C)2020. American Geophysical Union. All Rights Reserved.

\author{
Stephanie Brown Krein ${ }^{1}$ iD, Mark Dietrich Behn² iD, and Timothy Lynn Grove ${ }^{1}$ iD \\ ${ }^{1}$ Department of Earth, Atmospheric and Planetary Sciences, Massachusetts Institute of Technology, Cambridge, MA, \\ USA, ${ }^{2}$ Department of Earth and Environmental Sciences, Boston College, Chestnut Hill, MA, USA
}

\begin{abstract}
To investigate whether the source of the globally occurring garnet signature in mid-ocean ridge basalt (MORB) is "true" (imparted by melting a garnet-bearing source) or "apparent" (produced without the involvement of garnet), we present the basalt petrogenesis model Petrogen. Petrogen is built on Kinzler and Grove (1992a, https://doi.org/10.1029/91JB02841) and Behn and Grove (2015, https://doi. org/10.1002/2015JB011885) and calculates the major element, trace element, and isotopic compositions of primary lherzolite-saturated mantle melts and their subsequent evolution to eruption. This model is experimentally calibrated for melting in the plagioclase, spinel, and garnet fields with and without small amounts of water. Petrogen predicts that garnet-lherzolite melting requires small mantle porosity $(\phi=\sim 0.1 \%)$ and enriched $(\mathrm{NaK} \#>0.1)$, hot $\left(>1400-1450^{\circ} \mathrm{C}\right)$, and damp mantle $(>350-700$ ppm water $)$ sources. When garnet-lherzolite melting does occur, the fraction of melting that takes place in the garnet field is not sufficient to impart a recognizable true garnet signature in the major and trace element composition of pooled melts except at ultraslow-spreading rates (half rate $\leq 0.5 \mathrm{~cm} / \mathrm{yr}$ ). Therefore, for ambiguous garnet trace element signatures in MORB to be "true" would require that they are near-fractional garnet-lherzolite melts or garnet-pyroxenite melts diluted by mixing in random proportions. While we do not test the process of random mixing, we find that near-fractional and pooled melts of variable major and trace element mantle peridotite compositions at different mantle potential temperatures can explain the range of garnet signatures in MORB. For spinel-peridotite melting to support garnet signatures requires mantle porosities $\phi=\sim 0.1 \%$; however, plagioclase-peridotite melting, under specific circumstances, can explain MORB garnet signatures with $\phi=\sim 1 \%$.
\end{abstract}

\section{Introduction: Ambiguous, True, and Apparent Garnet Signatures}

Mid-ocean ridge basalts (MORBs) exhibit compositional diversity in major elements, trace elements, and isotopes. These variations reflect variations in mantle potential temperature $\left(T_{\mathrm{P}}\right)$, mantle composition, and mantle upwelling velocity (Dick et al., 1984; Kinzler \& Grove, 1992a; Klein \& Langmuir, 1987, 1989). Identifying MORBs that involve melting of garnet-bearing sources can aid in distinguishing among these mantle variables and help to constrain the fundamental processes occurring within the Earth's mantle, but the threshold for identifying true garnet signatures is uncertain. The trace elements and isotopes found in many MORBs (Table 1 and Figure 1) suggest evidence for melting of garnet-bearing sources (Beattie, 1993b; Hellebrandet al., 2002; Hirschmann \& Stolper, 1996; Salters \& Hart, 1989; Scott et al., 2018; Stracke et al., 2000; Waters et al., 2011), yet these same signatures, commonly identified as garnet signatures, can also be produced without melting a garnet-bearing source (e.g., Donnelly et al., 2004; Chauvel \& Blichert-Toft, 2001; Landwehr et al., 2001; Turner et al., 2000; Wood et al., 1999). These signatures might, therefore, only be apparent garnet signatures. In this paper, we detail how major elements can help resolve the origins of these ambiguous garnet signatures in MORBs. To this end, we develop a new garnetspinel-plagioclase lherzolite melting model and use it to determine the conditions under which garnet-lherzolite melting is expected to occur, and the range of distinctive major element, trace element, and isotope signatures that garnet-lherzolite melts impart.

Melts of garnet-bearing sources are distinct (Figure 1) due to the unique trace element partitioning behavior of garnet (see section 2.2.2). Garnet-equilibrated melts, as exemplified by diamond-bearing kimberlites (Figure 1), have low abundances of heavy rare earth elements (HREEs), high ratios of light rare earth element (LREE) to middle rare earth element (MREE) abundances (e.g., high LREE/HREE slopes such as high $\mathrm{La} / \mathrm{Sm}$ and low Sm/Nd), steep MREE/HREE slopes (e.g., high $\mathrm{Sm} / \mathrm{Yb}$ ), and low HREE/HFSE slopes 


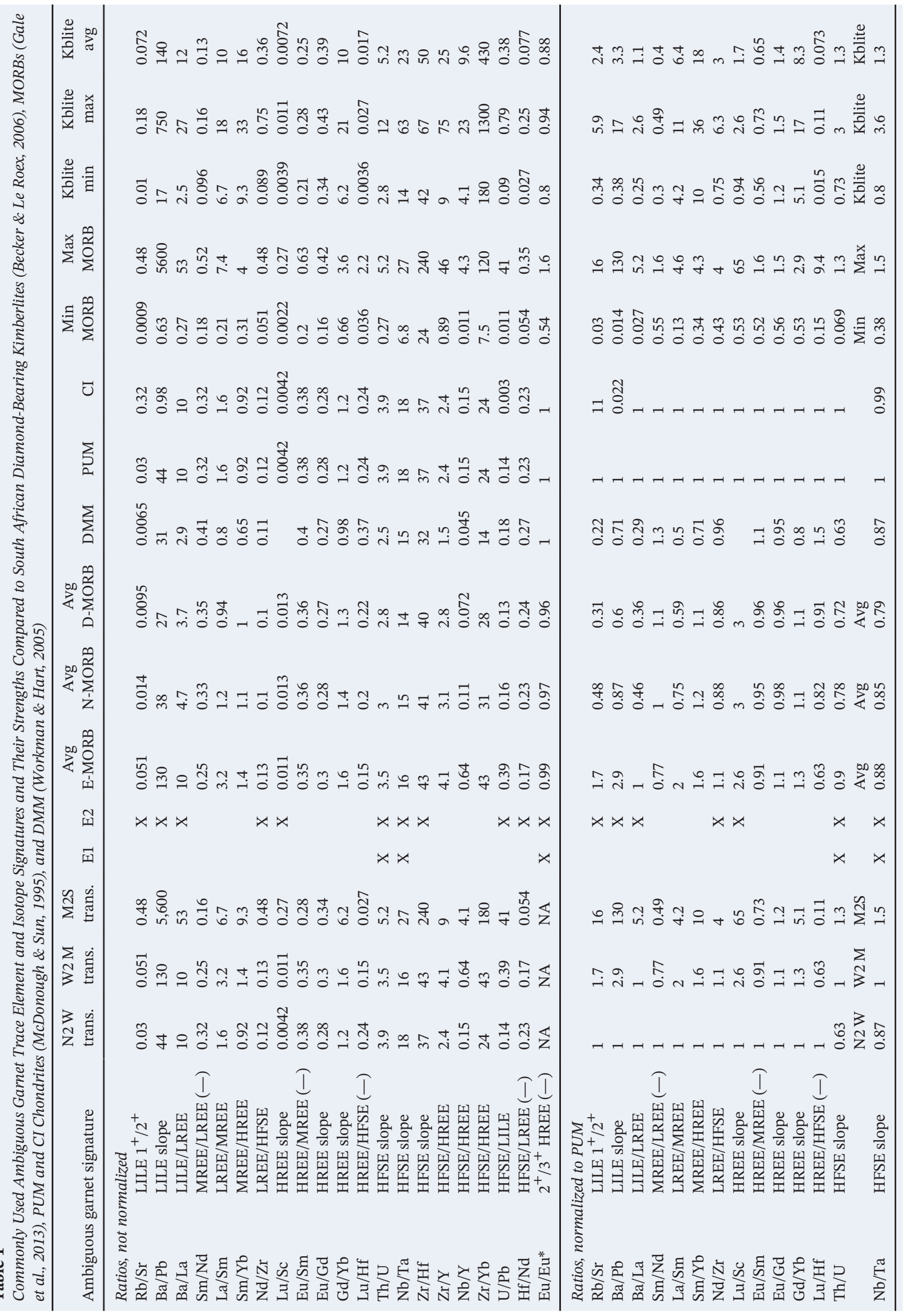




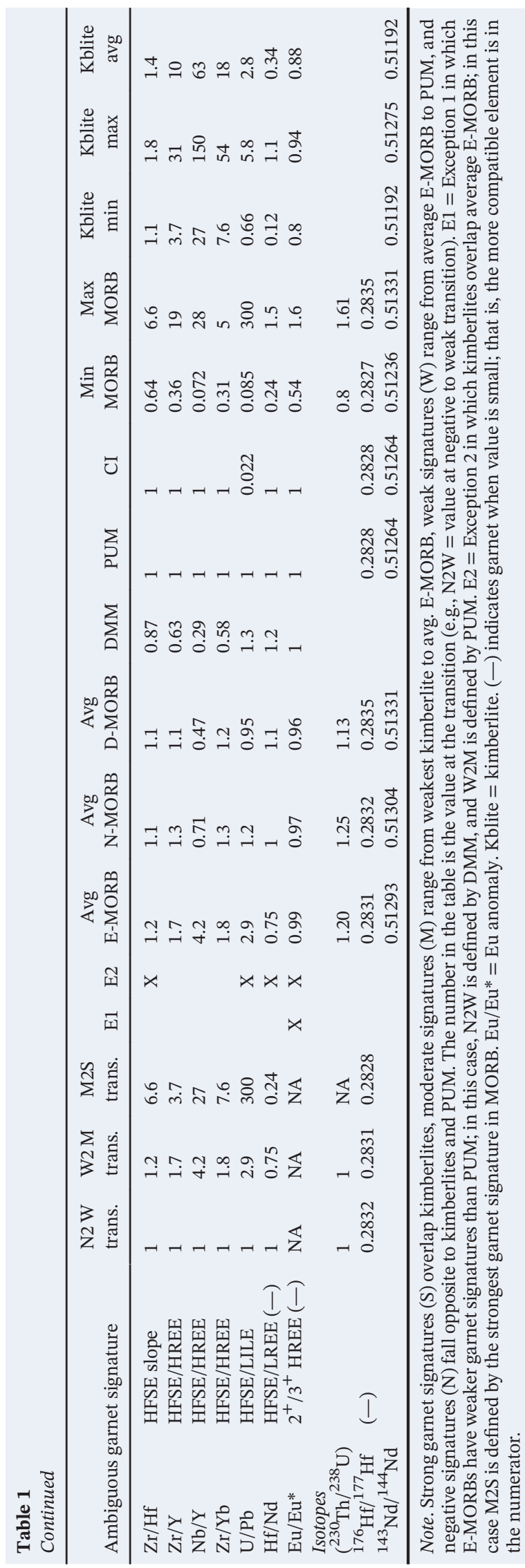


(a)
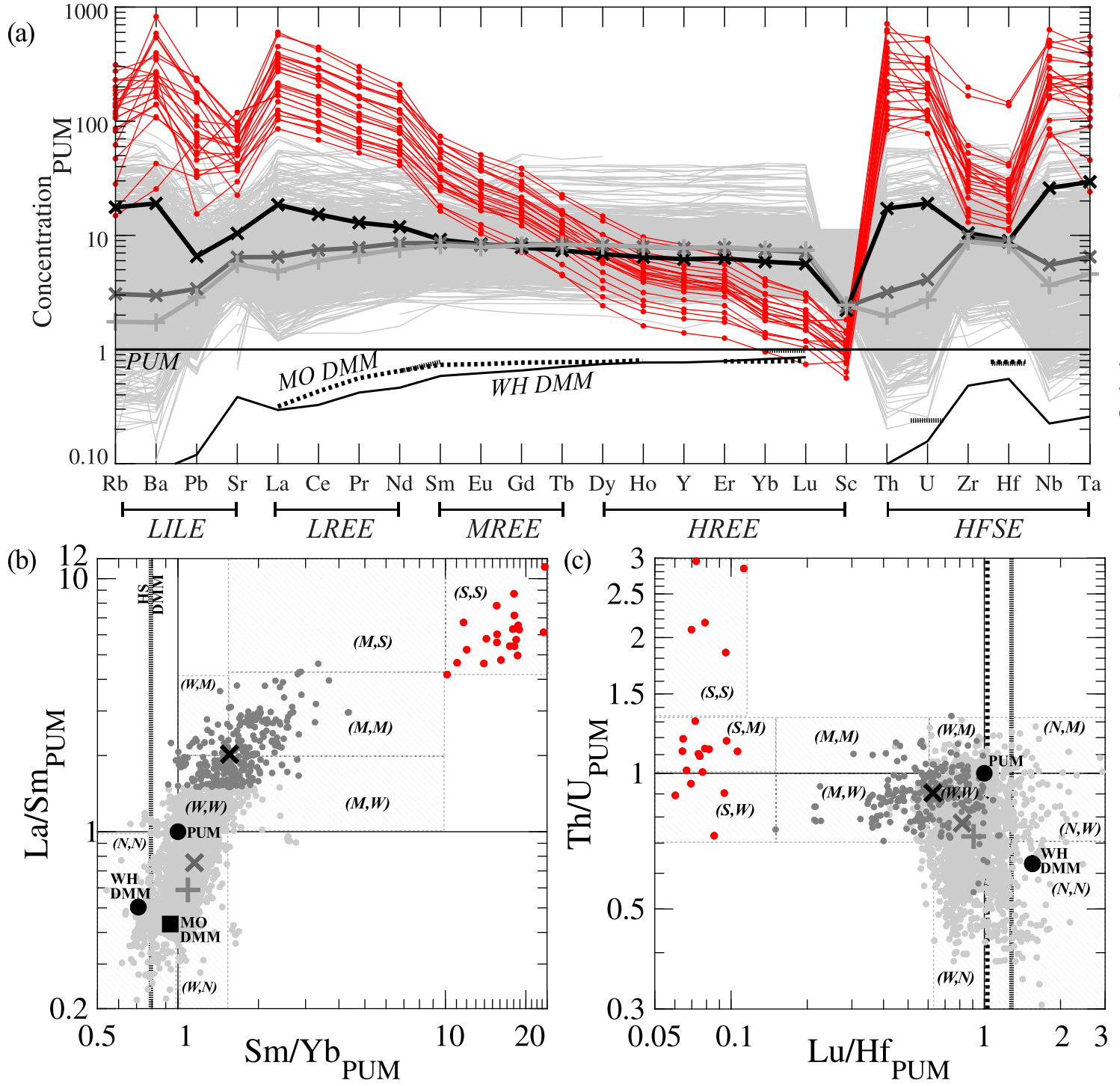

DATA

MORB

Gale et al., 2013

- or A All MORB

E-MORB as

$\mathrm{La} / \mathrm{Sm}_{\mathrm{PUM}}>1.5$
in $B$ ) and $($ )

* or $\mathbf{X}$ Avg. E-MORB

* or $\times$ Avg. N-MORB

$+o r+$ Avg. D-MORB

Kimberlites

$\rightarrow-o r \cdot$ South Africa

Mantle Sources

-or PUM

- or WH DMM

... or MO DMM

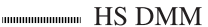

Garnet Signature

Strengths

$S=$ strong

$M=$ moderate

$W=$ weak

$N=$ negative

Figure 1. Plots showing trace element garnet signatures in MORB, kimberlites (Becker \& Le Roex, 2006), primitive upper mantle (PUM), and depleted MORB mantle (DMM) in (a) spider diagrams and (b and c) ratio-ratio plots. Striped boxes in (b) and (c) define regions of garnet signature strengths in the $x$ and $y$ directions (see Table 1). In general, kimberlites have "strong" garnet signatures, average E-MORBs have "moderate" garnet signatures, and average $\mathrm{N}$ - and D-MORB have "weak" to "negative" garnet signatures. For example, N- and D-MORBs have weak Sm/Yb garnet signatures and negative La/Sm garnet signatures and plot in the field of "(W,N)" (panel b). Gale et al. (2013) E-MORBs exhibit all combinations of weak to moderate signatures: (W,M), (W,W), $(\mathrm{M}, \mathrm{M})$, and $(\mathrm{M}, \mathrm{W})$. DMM from WH = Workman and Hart (2005), MO = McKenzie and O'Nions (1991), and HS = Hirschmann and Stolper (1996).

$(\mathrm{HFSE}=$ high field strength element) (e.g, low Lu/Hf). At long timescales, over billions of years, the high $\mathrm{Lu} / \mathrm{Hf}$ and high $\mathrm{Sm} / \mathrm{Nd}$ ratios of residues that melted in the presence of garnet lead to sources with higher ${ }^{176} \mathrm{Hf} /{ }^{177} \mathrm{Hf}$ and ${ }^{143} \mathrm{Nd} /{ }^{144} \mathrm{Nd}$ compositions than would be without melting of garnet-bearing sources (Chauvel \& Blichert-Toft, 2001; Salters \& Hart, 1989). Garnet-equilibrated melts can also have high Th/U ratios that generate short-lived isotopic ${ }^{230} \mathrm{Th}$ excesses (defined as the activity ratio $\left({ }^{230} \mathrm{Th}\right) /\left({ }^{238} \mathrm{U}\right)>1$ ) that decay back to secular equilibrium (defined as $\left({ }^{230} \mathrm{Th}\right) /\left({ }^{238} \mathrm{U}\right)=1$ ) within $375 \mathrm{kyr}$ of melting (Elliott \& Spiegelman, 2014, and references therein).

MORBs found all along the global ridge system (e.g., Donnelly et al., 2004) display a wide and continuous spectrum of these different trace element and isotope garnet signatures (Figure 1 and Table 1). In addition, a single MORB can have different garnet signatures with different "strengths." For example, average normal MORB (N-MORB) has slightly elevated $\mathrm{Sm} / \mathrm{Yb}$ but lower La/Sm than primitive upper mantle (PUM) 

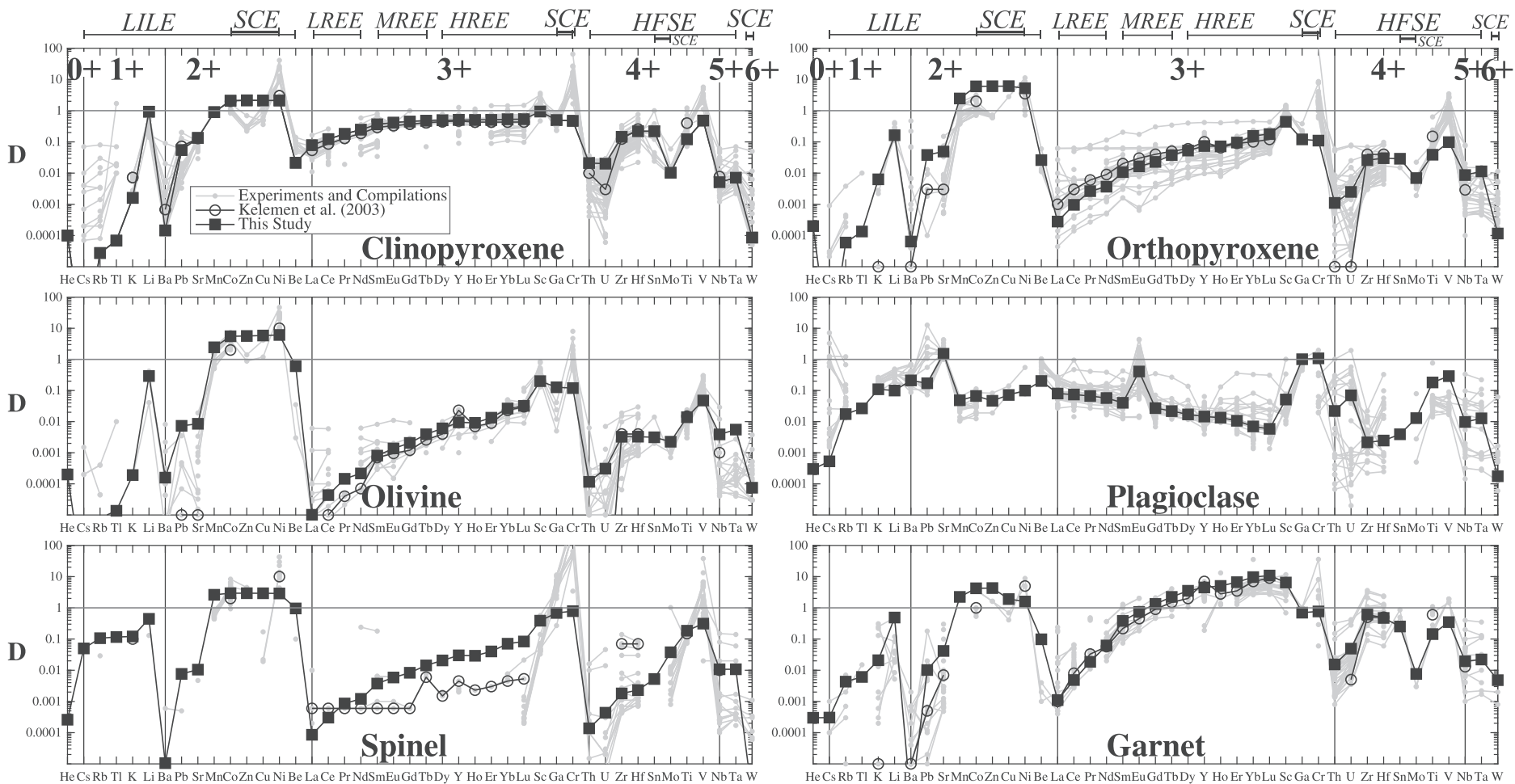

Figure 2. Mineral-melt trace element partition coefficients (D) used in this study (black squares, values given in Table 3) calculated for the 43 elements provided in Gale et al. (2013) compared to Kelemen et al. (2003) (open circles) and other partition coefficient experiments and compilations (gray circles). Elements ordered first by valence (appropriate for MORB) and then by ionic radius. This order automatically sorts the elements into large ion lithophile (LILE), light rare earth element (LREE), middle rare earth elements (MREE), heavy rare earth element (HREE), and high-field strength elements (HFSE), with siderophile-chalcophile elements (SCEs) mixed throughout. References for experimental partition coefficients are in section S8.

(field "W,N" in Figure 1b). The problem with using these garnet signatures (that are highly variable between samples and within a single sample) to identify melts of garnet-bearing sources is that they can be generated by melting both garnet-bearing sources and non-garnet-bearing sources. Even MORBs with the strongest garnet signatures, enriched MORBs (E-MORBs, Figure 1), have been attributed to melting both with garnet (Waters et al., 2011) and without garnet (Donnelly et al., 2004). When garnet is invoked, mixing of melts is typically required to explain the relatively small signatures in MORBs (Hirschmann \& Stolper, 1996; Waters et al., 2011), but not always (e.g., Elkins et al., 2016).

The ambiguous origin of garnet signatures also extends to whether or not N-MORBs indicate the melting of a globally occurring garnet-bearing source (Hirschmann \& Stolper, 1996), that in turn depends on whether or not the N-MORB source (depleted MORB mantle or "DMM") contains a preexisting garnet signature. For example, Hirschmann and Stolper (1996) required garnet to explain the $\mathrm{Sm} / \mathrm{Yb}, \mathrm{Lu} / \mathrm{Hf}, \mathrm{Sm} / \mathrm{Nd}$, and U-series disequilibria in N-MORB based on melting a DMM source generated by removing a $2 \%$ garnet-peridotite melt from PUM (Figure 1). In contrast, McKenzie and O'Nions (1991) found no evidence of $\mathrm{Sm} / \mathrm{Yb}$ garnet signatures in N-MORBs because they assumed a different DMM source with a higher initial $\mathrm{Sm} / \mathrm{Yb}$ ratio (Figures 1a and $1 \mathrm{~b}$ ).

Hirschmann and Stolper (1996) further reasoned that if the multiple garnet signatures in N-MORB were from melting garnet peridotite, then $T_{\mathrm{P}}$ would be very hot, and the oceanic crust would be thicker than the measured $6.5 \pm 1 \mathrm{~km}$ (White \& Klein, 2014). They concluded that the N-MORB garnet signature is not directly related to melting of DMM but rather from melting a small percentage $(\sim 5 \%)$ of a garnet-pyroxenite component globally contained as veins or layers within DMM. Yet, while the crustal thickness constraint invoked by Hirschmann and Stolper (1996) is critical for understanding mantle conditions at mid-ocean ridges (MORs), crustal thickness strongly depends on the efficiency of pooling (Hebert \& Montési, 2010; Montési et al., 2011). Specifically, for a fixed mantle potential temperature and melt productivity, less efficient pooling will reduce crustal thickness (Behn \& Grove, 2015), thereby relaxing the constraint on $T_{\mathrm{P}}$. 
The final evidence used by Hirschmann and Stolper (1996) for garnet pyroxenite in the N-MORB source is the ${ }^{230}$ Th excess found in young MORB (e.g., Elliott \& Spiegelman, 2014; Lundstrom, 2003, and references therein); however, this garnet signature has also been found to be apparent (Landwehr et al., 2001; Turner et al., 2000; Wood et al., 1999). Even though garnet is thought to be the most likely phase to produce ${ }^{230} \mathrm{Th}$ excesses (Beattie, 1993b) (Figure 2), it is also well known that high-pressure low-CaO clinopyroxene in spinel and garnet peridotite can generate ${ }^{230} \mathrm{Th}$ excesses, but to a lesser magnitude than garnet (Figure 2) (e.g., Landwehr et al., 2001). While experiments suggest that basalts with $\left({ }^{230} \mathrm{Th}\right) /\left({ }^{238} \mathrm{U}\right)$ greater than $\sim 1.34$ uniquely require garnet and cannot be explained by clinopyroxene (Landwehr et al., 2001), this threshold value is not well constrained and is very close to the known maximum values in MORB of $\sim 1.4-1.5$ (Elliott \& Spiegelman, 2014). Because ${ }^{230} \mathrm{Th}$ excess models are very sensitive to the assumed U and Th partition coefficients (Elliott \& Spiegelman, 2014; Jull et al., 2002), MORBs with $\left({ }^{230} \mathrm{Th}\right) /\left({ }^{238} \mathrm{U}\right)>\sim 1.1-1.2$ are often still attributed to garnet (e.g., Elkins et al., 2008), especially when other garnet signatures are included (e.g., Waters et al., 2011).

To address these ambiguities related to the origin of garnet signatures in MORB and MORB crustal thickness, here we provide new, independent major element constraints on their origin using our new garnetspinel-plagiolcase near-fractional peridotite melting model Petrogen. Major elements are as unique to garnet-lherzolite melts as trace elements and isotopes (Grove et al., 2013; Herzberg \& Asimow, 2015; Walter, 1998) and should correlate with other trace element and long- and short-lived isotopic indicators of deep melting in the garnet-stability field (Hirschmann \& Stolper, 1996; Sims et al., 2002). While it is beyond the scope of this study to also model garnet pyroxenite melting, we find that we can explain most, but not all, garnet signatures in E-MORBs, N-MORBs, and D-MORBs as near-fractional and pooled melts of compositionally variable spinel and plagioclase peridotite without involving garnet peridotite or garnet pyroxenite.

\section{Methods}

Petrogen is based on the nonmodal melting model architecture of Kinzler and Grove (1992b), Kinzler and Grove (1992a), Kinzler (1997), Till et al. (2012), Grove et al. (2013), and Behn and Grove (2015) and can be coupled with a geodynamical model of mantle flow and spreading rate (Behn \& Grove, 2015). As in Behn and Grove (2015), we fractionally crystallize modeled primary melts from pressures of 1 atm to $10 \mathrm{kbar}$ using Yang et al. (1996). Petrogen differs from previous models by the addition of garnet-lherzolite melting, compositionally dependent mantle mode and phase boundary calculations, a critical retained melt fraction (i.e., mantle porosity, $\phi$ ) for melt extraction, trace elements, and small amounts of water. We use Petrogen to constrain the mantle potential temperatures and bulk compositions under which garnet-peridotite melting is expected to occur during MORB generation and to constrain the major, trace element, and $\left({ }^{230} \mathrm{Th}\right) /\left({ }^{238} \mathrm{U}\right)$ compositions of the near-fractional and pooled melts generated under those conditions.

We can relate the near-fractional and pooled melts calculated by Petrogen to concepts of melt focusing and melt transport. For example, near-fractional melts are relevant to melts that are extracted with minimal mixing and without reequilibrating with shallower mantle or crust. These highly variable melts are potentially isolated and preserved within channels (Aharonov et al., 1995; Katz \& Weatherley, 2012; Kelemen et al., 1995; Spiegelman \& Kelemen, 2003; Weatherley \& Katz, 2012, 2016). At shallow pressures, near-fractional melts are referred to as melts produced by reactive flow (Spiegelman \& Kelemen, 2003) (see section S1 in the supporting information). Pooled melts (i.e., mixed focused melts), by contrast, are more relevant to melts that equilibrate by equilibrium porous flow (Spiegelman \& Elliott, 1993), with a few caveats that Petrogen pooled melts record melting over a range of pressures (unless Petrogen is set to model batch melting, see below). By tracking $\phi$-dependent near-fractional melts and pooled melts, Petrogen is essentially a two-porosity model with reactive flow that tracks both major and trace elements as well as isotopes.

\subsection{Mantle Source Variables}

The mantle variables in Petrogen are the major and trace element composition of the source, the mantle potential temperature of the source, and the upwelling velocity of the source imposed by the spreading rate. Each individual Petrogen simulation models the melting of a single lithology, but because it is simple to change peridotite source compositions in Petrogen, we also model the independent melting of multiple peridotite lithologies. This independent, multiple-lithology source approach is also commonly used by trace ele- 


\begin{tabular}{|c|c|c|c|c|c|c|c|c|c|c|c|c|c|c|}
\hline & Reference & $\mathrm{NaK} \#$ & $\mathrm{Mg} \#$ & $\frac{\mathrm{CaO}}{\mathrm{Al}_{2} \mathrm{O}_{3}}$ & $\mathrm{SiO}_{2}$ & $\mathrm{TiO}_{2}$ & $\mathrm{Al}_{2} \mathrm{O}_{3}$ & $\mathrm{Cr}_{2} \mathrm{O}_{3}$ & $\mathrm{FeO}$ & $\mathrm{MgO}$ & $\mathrm{CaO}$ & $\mathrm{Na}_{2} \mathrm{O}$ & $\mathrm{K}_{2} \mathrm{O}$ & Total \\
\hline WH-DMM-2 & Behn and Grove (2015) & 0.060 & 0.895 & 0.828 & 44.76 & 0.12 & 3.72 & 0.47 & 8.25 & 39.40 & 3.08 & 0.195 & 0.000 & 100.0 \\
\hline DepXeno & Mandler (2016) & 0.061 & 0.905 & 0.944 & 43.90 & 0.05 & 1.80 & 0.42 & 8.00 & 43.00 & 1.70 & 0.100 & 0.010 & 99.0 \\
\hline HZ-PUM-2 & Behn and Grove (2015) & 0.068 & 0.900 & 0.852 & 46.31 & 0.16 & 3.64 & 0.47 & 7.67 & 38.89 & 3.10 & 0.223 & 0.003 & 100.5 \\
\hline WH-DMM-1 & Behn and Grove (2015) & 0.071 & 0.894 & 0.812 & 44.81 & 0.12 & 3.86 & 0.47 & 8.23 & 39.12 & 3.14 & 0.240 & 0.000 & 100.0 \\
\hline Eroded & O'Neill and Palme (2008) & 0.079 & 0.890 & 0.821 & 45.40 & 0.18 & 4.29 & 0.37 & 8.10 & 36.77 & 3.52 & 0.281 & 0.019 & 98.9 \\
\hline MM3 & Baker and Stolper (1994) & 0.080 & 0.905 & 0.897 & 45.50 & 0.11 & 3.98 & 0.68 & 7.18 & 38.30 & 3.57 & 0.310 & 0.000 & 99.6 \\
\hline WKR & Walter (1998) & 0.082 & 0.892 & 0.810 & 44.90 & 0.16 & 4.26 & 0.41 & 8.02 & 37.30 & 3.45 & 0.220 & 0.090 & 98.8 \\
\hline WH-DMM & Workman and Hart (2005) & 0.083 & 0.894 & 0.796 & 44.71 & 0.13 & 3.98 & 0.57 & 8.18 & 38.73 & 3.17 & 0.280 & 0.006 & 99.8 \\
\hline HZ-PUM-1 & Behn and Grove (2015) & 0.083 & 0.899 & 0.811 & 46.33 & 0.17 & 3.94 & 0.47 & 7.66 & 38.45 & 3.19 & 0.281 & 0.007 & 100.5 \\
\hline $\mathrm{KLB} 1+\mathrm{Al}$ & Balta et al. (2011) & 0.089 & 0.891 & 0.475 & 43.33 & 0.11 & 6.28 & 0.31 & 8.27 & 38.08 & 2.98 & 0.290 & 0.000 & 99.7 \\
\hline LeaModPerid & Palme and O'Neill (2003) & 0.090 & 0.890 & 0.813 & 45.40 & 0.21 & 4.49 & 0.37 & 8.10 & 36.77 & 3.65 & 0.330 & 0.031 & 99.4 \\
\hline FertXeno & Mandler (2016) & 0.093 & 0.892 & 0.872 & 45.00 & 0.15 & 3.90 & 0.37 & 8.20 & 38.00 & 3.40 & 0.320 & 0.030 & 99.4 \\
\hline PrimXenos & Jagoutz et al. (1979) & 0.093 & 0.897 & 0.882 & 45.16 & 0.22 & 3.97 & 0.46 & 7.82 & 38.30 & 3.50 & 0.330 & 0.031 & 99.8 \\
\hline KLB & Carter (1970) & 0.094 & 0.875 & 0.625 & 42.86 & 0.33 & 6.99 & 0.18 & 8.97 & 35.07 & 4.37 & 0.450 & 0.003 & 99.2 \\
\hline KLB-1 & Davis et al. (2009) & 0.094 & 0.896 & 0.875 & 44.84 & 0.11 & 3.51 & 0.32 & 8.20 & 39.52 & 3.07 & 0.300 & 0.020 & 99.9 \\
\hline LeaModPerid & McDonough and Sun (1995) & 0.099 & 0.893 & 0.798 & 45.00 & 0.20 & 4.45 & 0.38 & 8.05 & 37.80 & 3.55 & 0.360 & 0.029 & 99.8 \\
\hline UM & Harris et al. (1967) & 0.099 & 0.910 & 0.889 & 44.20 & 0.10 & 2.70 & 0.30 & 7.30 & 41.30 & 2.40 & 0.250 & 0.015 & 98.6 \\
\hline HZ-PUM & Hart and Zindler (1986) & 0.102 & 0.899 & 0.791 & 45.96 & 0.18 & 4.06 & 0.47 & 7.54 & 37.78 & 3.21 & 0.332 & 0.032 & 99.6 \\
\hline C1 BSE & Hart and Zindler (1986) & 0.102 & 0.899 & 0.813 & 49.77 & 0.17 & 3.48 & 0.41 & 6.91 & 34.65 & 2.83 & 0.293 & 0.028 & 98.5 \\
\hline Zabargad & Bonatti et al. (1986) & 0.104 & 0.888 & 0.821 & 44.70 & 0.15 & 3.90 & 0.00 & 8.50 & 38.00 & 3.20 & 0.340 & 0.030 & 98.8 \\
\hline Peridotites & Lyubetskaya and Korenaga (2007) & 0.104 & 0.898 & 0.793 & 44.95 & 0.16 & 3.52 & 0.39 & 7.97 & 39.50 & 2.79 & 0.300 & 0.023 & 99.6 \\
\hline MORBHarz & Green (1979) & 0.106 & 0.901 & 0.773 & 45.00 & 0.17 & 4.40 & 0.45 & 7.60 & 38.80 & 3.40 & 0.400 & 0.003 & 100.2 \\
\hline BSE & Taylor and McLennan (1985) & 0.111 & 0.887 & 0.795 & 49.90 & 0.16 & 3.65 & 0.44 & 8.00 & 35.15 & 2.90 & 0.340 & 0.022 & 100.6 \\
\hline Pyrolite & Ringwood (1975) & 0.119 & 0.896 & 0.674 & 45.10 & 0.20 & 4.60 & 0.30 & 7.87 & 38.10 & 3.10 & 0.400 & 0.020 & 99.7 \\
\hline Thaba Putsoa & Kushiro (1996) & 0.126 & 0.868 & 1.185 & 43.70 & 0.25 & 2.75 & 0.28 & 10.05 & 37.22 & 3.26 & 0.330 & 0.140 & 98.0 \\
\hline GarPeridotite & Carswell (1968) & 0.140 & 0.899 & 0.925 & 44.66 & 0.19 & 2.80 & 0.45 & 8.24 & 40.97 & 2.59 & 0.300 & 0.120 & 100.3 \\
\hline Lashaine & Rhodes and Dawson (1975) & 0.141 & 0.919 & 0.671 & 43.97 & 0.07 & 1.64 & 0.49 & 7.02 & 44.73 & 1.10 & 0.120 & 0.060 & 99.2 \\
\hline FertXenoNa & Mandler and Grove (2016) & 0.171 & 0.892 & 0.872 & 44.55 & 0.15 & 3.86 & 0.37 & 8.12 & 37.62 & 3.37 & 0.617 & 0.080 & 98.7 \\
\hline FertXenoK & Mandler and Grove (2016) & 0.171 & 0.892 & 0.872 & 44.55 & 0.15 & 3.86 & 0.37 & 8.12 & 37.62 & 3.37 & 0.417 & 0.280 & 98.7 \\
\hline DepXenoNa & Mandler (2016) & 0.214 & 0.905 & 0.944 & 43.46 & 0.05 & 1.78 & 0.42 & 7.92 & 42.57 & 1.68 & 0.399 & 0.060 & 98.3 \\
\hline Kimberlite & O'Hara et al. (1975) & 0.246 & 0.931 & 0.684 & 45.19 & 0.05 & 1.52 & 0.39 & 5.54 & 41.80 & 1.04 & 0.180 & 0.160 & 95.9 \\
\hline
\end{tabular}

ment melting models (e.g., Koornneef et al., 2012). Future work using Petrogen could consider mixing between the near-fractional and pooled melts generated by multiple sources with different major and trace element compositions.

\subsubsection{Major Element Compositions of Mantle Sources}

We use 31 previously proposed major element mantle bulk compositions (Table 2) that exhibit two independent vectors of alkali and iron fertility. Alkali fertility is indicated by high $\mathrm{NaK} \#=\frac{\mathrm{Na}_{2} \mathrm{O}+\mathrm{K}_{2} \mathrm{O}}{\mathrm{CaO}+\mathrm{Na}_{2} \mathrm{O}+\mathrm{K}_{2} \mathrm{O}}$ in $\mathrm{wt} \%$, and iron fertility is indicated by low $\mathrm{Mg} \#=\frac{\mathrm{MgO}}{\mathrm{MgO}+\mathrm{FeO}}$ in mol. Depleted mantles have low NaK\#s and high Mg\#s. Refertilized depleted mantles have high NaK\#s and high Mg\#s, while enriched mantles have high NaK\#s and low Mg\#s. We calculate initial near-solidus subsolidus mantle modes as a function of pressure for these bulk compositions by mass balance (see sections S2-S4).

\subsubsection{Trace Element Compositions of Mantle Sources}

We primarily use two reference trace element source compositions: Workman and Hart (2005) depleted MORB mantle (WH-DMM) and McDonough and Sun (1995) PUM. We allow for source water contents up to $1,000 \mathrm{ppm}$ above nominally anhydrous conditions. We use PUM as a reference enriched trace element source because it contains abundances for nearly all trace elements of interest. Other proposed sources, including WH-DMM, are typically more limited in which elements they provide. A reference source with a large number of trace element compositions is useful because, unlike major elements, trace elements do not control phase equilibria, and so changing the specific trace element source composition only causes melt compositions to shift by the same relative change made in the source (Shaw, 2000) (see section 3.2.2). We use this principle to calculate a new potential DMM composition in section 3.3. While it is beyond the scope of 
Table 3

Partition Coefficients Used in This Study (Shown in Figure 2) Ordered by Their Most Appropriate Valance for MORB Melting and Then by Decreasing Ionic Radius

\begin{tabular}{|c|c|c|c|c|c|c|c|c|}
\hline Element & Charge & Type & CPX & OPX & OLIV & PLAG & SPINEL & GARNET \\
\hline $\mathrm{He}$ & 0 & nb. gas & 0.00010 & 0.00020 & 0.00020 & 0.00030 & 0.00026 & 0.00030 \\
\hline Cs & $1+$ & LILE & 0.00000 & 0.00000 & 0.00000 & 0.00053 & 0.05012 & 0.00030 \\
\hline $\mathrm{Rb}$ & $1+$ & LILE & 0.00003 & 0.00006 & 0.00001 & 0.01744 & 0.10651 & 0.00431 \\
\hline $\mathrm{Tl}$ & $1+$ & chalc. & 0.00007 & 0.00013 & 0.00001 & 0.02664 & 0.11601 & 0.00610 \\
\hline K & $1+$ & LILE & 0.00160 & 0.00631 & 0.00019 & 0.10954 & 0.12093 & 0.02094 \\
\hline $\mathrm{Li}$ & $1+$ & LILE & 0.92738 & 0.16322 & 0.29192 & 0.09976 & 0.44434 & 0.48910 \\
\hline $\mathrm{Ba}$ & $2+$ & LILE & 0.00015 & 0.00006 & 0.00016 & 0.21086 & 0.00001 & 0.00000 \\
\hline $\mathrm{Pb}$ & $2+$ & LILE & 0.05476 & 0.03803 & 0.00731 & 0.17101 & 0.00764 & 0.01015 \\
\hline $\mathrm{Sr}$ & $2+$ & LILE & 0.13368 & 0.04901 & 0.00851 & 1.51574 & 0.01047 & 0.04152 \\
\hline $\mathrm{Mn}$ & $2+$ & LILE & 0.89369 & 2.45592 & 2.44393 & 0.04849 & 2.62038 & 2.24149 \\
\hline Co & $2+$ & sidero. & 2.08117 & 6.00748 & 5.52770 & 0.06660 & 2.94414 & 4.23085 \\
\hline $\mathrm{Zn}$ & $2+$ & sidero. and litho. & 2.14253 & 6.06833 & 5.64975 & 0.04667 & 2.94420 & 4.29627 \\
\hline $\mathrm{Cu}$ & $2+$ & sidero. and chalc. & 2.12117 & 6.10577 & 5.85458 & 0.07194 & 2.93031 & 1.91281 \\
\hline $\mathrm{Ni}$ & $2+$ & sidero. & 2.12336 & 5.21626 & 6.09278 & 0.09965 & 2.89185 & 1.59485 \\
\hline $\mathrm{Be}$ & $2+$ & REE & 0.02145 & 0.02603 & 0.60494 & 0.20186 & 0.95627 & 0.09818 \\
\hline $\mathrm{La}$ & $3+$ & LREE & 0.07810 & 0.00028 & 0.00001 & 0.08007 & 0.00009 & 0.00110 \\
\hline $\mathrm{Ce}$ & $3+$ & LREE & 0.12246 & 0.00096 & 0.00004 & 0.07440 & 0.00030 & 0.00486 \\
\hline Pr & $3+$ & LREE & 0.17952 & 0.00263 & 0.00015 & 0.06650 & 0.00086 & 0.01860 \\
\hline $\mathrm{Nd}$ & $3+$ & LREE & 0.24489 & 0.00366 & 0.00022 & 0.05725 & 0.00121 & 0.06220 \\
\hline $\mathrm{Sm}$ & $3+$ & MREE & 0.36542 & 0.01074 & 0.00081 & 0.04026 & 0.00374 & 0.38055 \\
\hline $\mathrm{Eu}$ & $2+$ & MREE & 0.41072 & 0.01643 & 0.00137 & 0.40812 & 0.00587 & 0.73805 \\
\hline $\mathrm{Gd}$ & $3+$ & MREE & 0.44592 & 0.02278 & 0.00207 & 0.02721 & 0.00831 & 1.33214 \\
\hline $\mathrm{Tb}$ & $3+$ & MREE & 0.47591 & 0.03766 & 0.00392 & 0.02174 & 0.01430 & 2.24130 \\
\hline Dy & $3+$ & HREE & 0.49227 & 0.05270 & 0.00607 & 0.01705 & 0.02065 & 3.52056 \\
\hline Y & $3+$ & HREE & 0.50809 & 0.07376 & 0.00945 & 0.01456 & 0.03000 & 4.49531 \\
\hline Ho & $3+$ & HREE & 0.50079 & 0.07180 & 0.00912 & 0.01342 & 0.02912 & 5.03202 \\
\hline Er & $3+$ & HREE & 0.50665 & 0.09529 & 0.01335 & 0.01064 & 0.04008 & 6.64625 \\
\hline $\mathrm{Yb}$ & $3+$ & HREE & 0.52891 & 0.15542 & 0.02637 & 0.00701 & 0.07089 & 9.64680 \\
\hline $\mathrm{Lu}$ & $3+$ & HREE & 0.53289 & 0.17784 & 0.03204 & 0.00587 & 0.08343 & 10.84327 \\
\hline $\mathrm{Sc}$ & $3+$ & HREE & 0.94061 & 0.44097 & 0.20000 & 0.05131 & 0.38680 & 6.47677 \\
\hline $\mathrm{Ga}$ & $3+$ & chalc. and litho. & 0.50162 & 0.12013 & 0.12692 & 1.01206 & 0.68573 & 0.70034 \\
\hline $\mathrm{Cr}$ & $3+$ & & 0.47213 & 0.10978 & 0.11959 & 1.08000 & 0.78329 & 0.76688 \\
\hline Th & $4+$ & HFSE & 0.01030 & 0.00111 & 0.00012 & 0.02200 & 0.00014 & 0.01540 \\
\hline $\mathrm{U}$ & $4+$ & HFSE & 0.01320 & 0.00249 & 0.00031 & 0.07000 & 0.00044 & 0.04937 \\
\hline $\mathrm{Zr}$ & $4+$ & HFSE & 0.14502 & 0.02589 & 0.00326 & 0.00216 & 0.00181 & 0.61064 \\
\hline $\mathrm{Hf}$ & $4+$ & HFSE & 0.21853 & 0.03001 & 0.00328 & 0.00246 & 0.00232 & 0.47445 \\
\hline $\mathrm{Sn}$ & $4+$ & sidero. and chalc. & 0.21899 & 0.02879 & 0.00314 & 0.00392 & 0.00524 & 0.25267 \\
\hline Mo & $4+$ & sidero. and chalc. & 0.01028 & 0.00691 & 0.00226 & 0.01294 & 0.03771 & 0.00763 \\
\hline $\mathrm{Ti}$ & $4+$ & HFSE & 0.12172 & 0.03873 & 0.01385 & 0.18158 & 0.18463 & 0.14406 \\
\hline V & $4+$ & & 0.48152 & 0.09803 & 0.04771 & 0.28958 & 0.31208 & 0.34900 \\
\hline $\mathrm{Nb}$ & $5+$ & HFSE & 0.00512 & 0.00864 & 0.00388 & 0.00972 & 0.01076 & 0.01946 \\
\hline $\mathrm{Ta}$ & $5+$ & HFSE & 0.00709 & 0.01134 & 0.00554 & 0.01275 & 0.01076 & 0.02212 \\
\hline $\mathrm{W}$ & $6+$ & sidero. & 0.00009 & 0.00012 & 0.00008 & 0.00018 & 0.00000 & 0.00482 \\
\hline
\end{tabular}

Note. This order essentially divides trace elements into large ion lithophile (LILE), rare earth elements (REEs), and high field strength elements (HFSE). This trace element order is a pseudo-Onouma diagram and allows multivalent elements to stand out. Note that $\mathrm{Y}$ and Ho switch position if sixfold coordinated radii are used.

this paper to investigate and test other possible trace element source compositions, we encourage future studies to use Petrogen to address questions related to the variability in mantle trace element composition in more detail.

\subsection{3. $T_{P}$ and Spreading Rates of Mantle Sources}

Mantle temperature is input into Petrogen as a vector representing temperature as a function of depth. The vector can be a simple adiabat or a more realistic thermal structure based on spreading rate calculated by a geophysical model. In this study, we explore ridge thermal structures calculated for the same range in mantle potential temperature $\left(T_{\mathrm{P}}=1300-1450^{\circ} \mathrm{C}\right)$ and half spreading rates $(0.5-10 \mathrm{~cm} / \mathrm{yr})$ as in Behn and Grove (2015). 


\subsection{Mantle Melting in Petrogen}

Petrogen is a near-fractional nonmodal melting model for major and trace elements that is solved using an incremental batch melting solution. Melting is predicted to begin and end by comparing, at each step, the mantle temperature to its melting temperature dictated by its major element composition and water content (see sections S5-S7 for details). The analytical solution to near-fractional melting is typically referred to as continuous or dynamic melting (Shaw, 2000; Zou \& Reid, 2001). In all cases, near-fractional melting uses a prescribed porosity, $\phi$, that a system must reach before primary melts are extracted. Near-fractional melting can be reduced to pure batch (i.e., equilibrium porous flow) and pure fractional melting by setting $\phi=1$ or $\phi=0$, respectively. Once $\phi$ is reached, any excess melt is extracted as a primary near-fractional melt, but the system always retains a melt mass (or melt fraction) $\phi$ that continuously changes to be in equilibrium with the evolving residual mantle. Therefore, the first extracted near-fractional melt is a batch melt at a degree of melting, $F$, equal to the porosity $(F=\phi)$. Compared to pure fractional melting $(\phi=0)$, near-fractional melting $(\phi>0)$ damps the quick extraction of very incompatible elements at the earliest stages (see Shaw, 2000).

Solutions using an incremental and a dynamic/continuous approach converge to within a few percent of each other when step sizes $(\mathrm{d} F)$ are small, even for highly incompatible elements such as $U$ and Th (Figure S1). To keep errors between the incremental and the analytical solutions in element concentrations and element-element ratios below $2 \%$ (Figure S1), we implement and use a default step size of $\mathrm{d} F=0.05 \%$ in Petrogen. We prefer the incremental batch melting approach because it allows us to calculate major and trace element compositions of melts simultaneously and to also introduce pressure, composition, and/or melt extent-dependent variables that change at each step. Variables can either be prescribed or calculated iteratively, such as the pressures of the phase transitions, melting reactions, partition coefficients, and $\phi$. This also includes melt productivity $\mathrm{d} F / \mathrm{d} P$, which depends on melt extent (Asimow et al., 1997) and water content (Asimow \& Langmuir, 2003).

\subsubsection{Mantle Porosity $\phi$ and Melt Productivity $\mathrm{d} F / \mathrm{d} P$}

We consider a range of mantle porosity, $\phi$, from $0.1-2 \%$ and explore how changing this parameter changes melting systematics. For reference, Behn and Grove (2015) instead extracted 90\% of the melt generated at each step. We assume a constant $\mathrm{d} F / \mathrm{d} P=1 \% / \mathrm{kbar}$ when melting is occurring under nominally anhydrous conditions (see section S7 for treatment under hydrous conditions). Behn and Grove (2015) previously explored a pressure-dependent $\mathrm{d} F / \mathrm{d} P$ and found that modeled melts did not reproduce MORBs as well as constant $\mathrm{d} F / \mathrm{d} P$. For this reason, and because pressure-dependent $\mathrm{d} F / \mathrm{d} P$ reduces the amount of garnet-lherzolite melting (melt productivity increases with degree of melting Asimow et al., 1997), we present the constant melt productivity results. Furthermore, our results assuming constant melt productivity are a helpful reference that allows us to better understand the origin of melt compositional variability prior to considering a complex variable $\mathrm{d} F / \mathrm{d} P$.

\subsubsection{Trace Element Partition Coefficients}

To model trace element melting, we use a set of constant partition coefficients that we calculated for the 43 trace elements in Gale et al. (2013) for relevant mantle minerals (see section S9). As an exception to the use of constant Ds for this paper, we implement a variable $\mathrm{D}_{\mathrm{U}}^{\mathrm{CPX}}$ and $\mathrm{D}_{\mathrm{Th}}^{\mathrm{CPX}}$ to better model ${ }^{230}$ Th excesses. Our calculated partition coefficients are similar to Kelemen et al. (2003), with the largest differences found for spinel, $\mathrm{D}_{\mathrm{Pb}}^{\mathrm{Oliv}}$, and $\mathrm{D}_{\mathrm{Sr}}^{\mathrm{Oliv}}$. In addition, we report Ds for plagioclase $\left(\mathrm{D}^{\mathrm{Plag}}\right)$, which were not included in Kelemen et al. (2003). Multivalent elements are not considered in the results or discussion.

To include the pressure-dependent behavior of $D_{U}^{C P X}$ and $D_{T h}^{C P X}$, we implemented a linear fit to pressure of the Ds given in Table 4 of Landwehr et al. (2001), which gives $\mathrm{D}_{\mathrm{Th}}^{\mathrm{CPX}}=0.28-0.0006 * P(\mathrm{kbar})$ and $\mathrm{D}_{\mathrm{U}}^{\mathrm{CPX}} /$ $\mathrm{D}_{\mathrm{Th}}^{\mathrm{CPX}}=0.73+0.02 * P($ kbar $)$. Above 30 kbar $\mathrm{D}_{\mathrm{U}}^{\mathrm{CPX}}$ and $\mathrm{D}_{\mathrm{Th}}^{\mathrm{CPX}}$ are held constant.

We do not vary $\mathrm{D}_{\mathrm{U}}^{\text {Garnet }}$ and $\mathrm{D}_{\text {Th }}^{\text {Garnet }}$ based on melt and garnet composition, but this known complexity (e.g., Elkins et al., 2008; van Westrenen et al., 2001) can be implemented in the future. In general, experiments and lattice-strain theory indicate that more calcium-rich garnet from more enriched peridotite and enriched pyroxenite will produce smaller ${ }^{230} \mathrm{Th}$ excesses (van Westrenen et al., 1999, 2001) compared to more mafic, less calcium-rich garnets from more depleted peridotite and depleted pyroxenite (Elkins et al., 2008). 

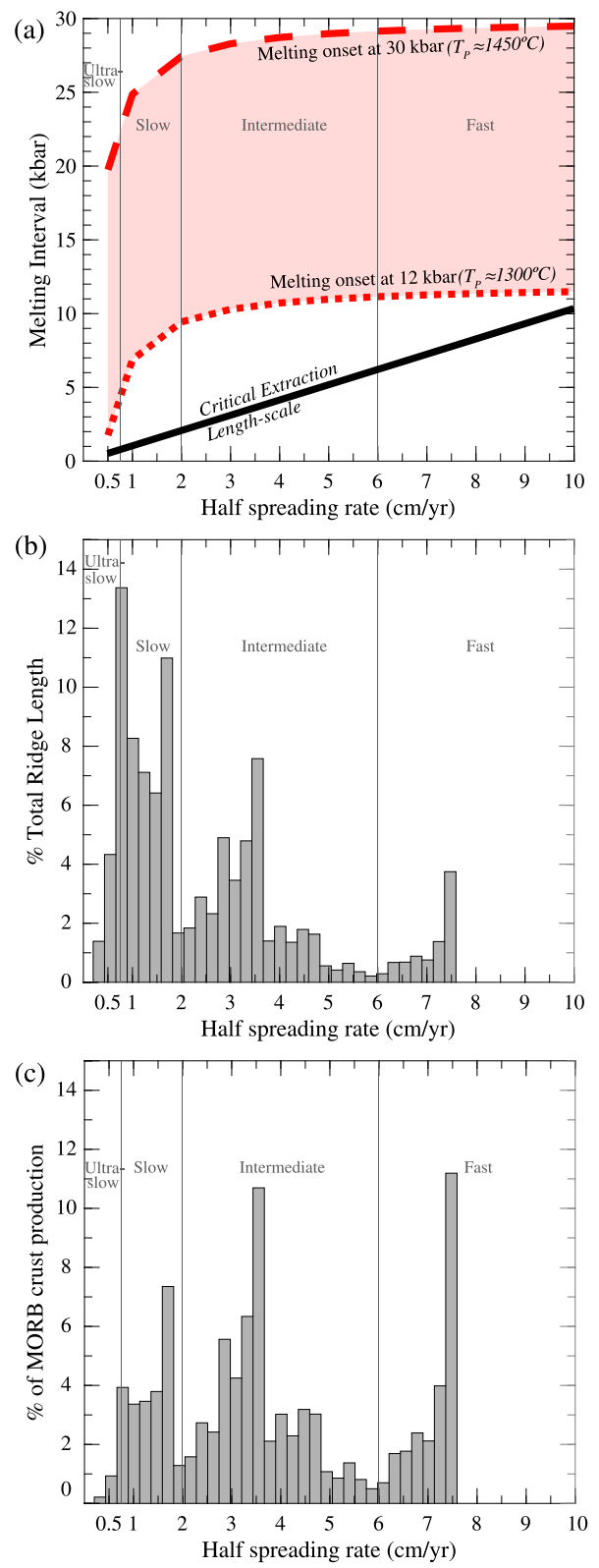

Figure 3. (a) Critical melt extraction length scale (in kbar) for local-element fractionation by the ingrowth of $\left({ }^{230} \mathrm{Th} /{ }^{232} \mathrm{Th}\right)$ as a function of spreading rate (black line) compared to expected estimated MOR melting intervals (dashed red lines). Length scale calculated as the melting interval needed for a parcel of mantle to return to secular equilibrium after melting ( $\sim 6.6$ half-lives of ${ }^{230} \mathrm{Th}$, after Spiegelman \& Elliott, 1993). (b and c) MOR spreading rate histograms by (b) total ridge length and (c) crustal production (approximately upwelling rate $\times$ segment length in $\mathrm{m}^{2} / \mathrm{s}$ ) using segments defined by Gale et al. (2013). Comparisons of (a)-(c) indicate that for all MOR spreading rates, melting columns extend over a pressure range greater than that needed for the mantle to return to secular equilibrium (red lines plot above the black line in a), so the residual mantle will always experience some local-element fractionation by the ingrowth of $\left({ }^{230} \mathrm{Th} /{ }^{232} \mathrm{Th}\right)$ that depends on $T_{\mathrm{P}}$. Upwelling rate is assumed to be passive and equal to $2 / p i \times$ the half spreading rate (Forsyth, 1993). Melt cessation estimated using Montési and Behn (2007).

\subsubsection{Pooling of Near-Fractional Melts and Mantle Melting Geometry}

The parental liquids of erupted MORBs are either liquids sampled incrementally along the near-fractional melting path or are mixtures of near-fractional primary melts ("pooled" melts). At MORs, melting regimes are triangularly shaped, such that melts produced "off-axis" extend to a lower degree than melts produced directly beneath the ridge axis ("on-axis"). The size and shape of the triangular melting regime are ultimately controlled by spreading rate and $T_{\mathrm{P}}$. Including off-axis melts in a pooled melt is important in erupted basalt chemistry (Plank \& Langmuir, 1992) and crustal thickness (Hebert \& Montési, 2010; Montési et al., 2011). Because pooling of all melts generated within the melting regime is not necessarily efficient (Hebert \& Montési, 2010; Montési et al., 2011), we calculate "narrow pooling" of melts generated in a narrow column $\sim 2 \mathrm{~km}$ wide directly beneath the ridge axis (referred to as "on-axis") to "full pooling" of all melts generated to a maximum distance of $150 \mathrm{~km}$ "off-axis." See section S10 for melt pooling calculations and details about other secondary processes.

\subsubsection{Defining the Measure of a True Garnet Signature, $\zeta$}

To compare the proportion of a melt that was derived from a garnet-bearing source (a "true garnet signature") to its major/trace/isotope "ambiguous garnet signature," we define the parameter, $\zeta$, to be the mass fraction of a melt that was formed in equilibrium with a garnet peridotite:

$$
\zeta=100 \times \frac{\mathrm{W}_{\mathrm{Gar}}^{\mathrm{L}}}{\mathrm{W}_{\mathrm{Gar}}^{\mathrm{L}}+\mathrm{W}_{\text {Spin }}^{\mathrm{L}}+\mathrm{W}_{\text {Plag }}^{\mathrm{L}}},
$$

where $\mathrm{W}_{\text {Gar }}^{\mathrm{L}}, \mathrm{W}_{\text {Spinel }}^{\mathrm{L}}$, and $\mathrm{W}_{\text {Plag }}^{\mathrm{L}}$ are the masses of a melt derived from the garnet-peridotite field, the spinel-peridotite field, and the plagioclaseperidotite field, respectively. $\zeta_{\mathrm{n}}$ refers to near-fractional melts and $\zeta_{\mathrm{P}}$ refers to pooled melts. Near-fractional melts that equilibrated with garnet-lherzolite source have $\zeta_{n}=100 \%$. Pooled melts composed of both melts of garnet lherzolite and melts of non-garnet-bearing sources have $\zeta_{\mathrm{P}} \leq 100 \%$. All near-fractional or pooled melts that have no contribution from a garnet-bearing source have $\zeta=0 \%$. In addition, any near-fractional melts produced in the garnet field after the exhaustion of garnet in the residue during melting have $\zeta=0 \%$, as those melt compositions will not reflect equilibrium with garnet. All calculations of $\zeta_{\mathrm{P}}$ use the estimated 2-D fully pooled melt model unless noted otherwise.

\subsection{Modeling of U-Series Disequilibria and Mantle/Melt Flow Styles}

U-series models can be generalized to a spectrum with two end-members (Elliott, 1997): net-element fractionation and local-element fractionation. Broadly speaking, net-element fractionation encompasses scenarios at the onset of melting, faster mantle upwelling, faster melting, and/or faster melt extraction (e.g., channelization). By contrast, local-element fractionation encompasses scenarios at higher degrees of melting, slower melt extraction, slower mantle upwelling, ingrowth of $\left({ }^{230} \mathrm{Th} /{ }^{232} \mathrm{Th}\right)$ in the residue, and/or treatment of melt transport (i.e., chromatographic fractionation/equilibrium porous flow/ fully reactive flow). The ultimate difference between the two end-members is the treatment of the "source," whereby in net-element fractionation the source is always taken to be the 
original, unmelted source (degree of melting dominated), while in local-element fractionation, the source is taken to be residue at the time of melting (partition dominated) (see section S11). The two end-members bracket the minimum and maximum $\left({ }^{230} \mathrm{Th} /{ }^{238} \mathrm{U}\right)$ a melt could have given its melting history (Elliott, 1997). By calculating both end-members, our model functions the same as two-porosity and fully reactive transport $\mathrm{U}$-series models that include both channelization and reactive/equilibrium porous flow (Elliott \& Spiegelman, 2014, and references therein). In particular, equilibrium porous flow models are similar to our local-element fractionation pooled melts. Channelized melts and melts produced by reactive melt transport are similar to our local-element fractionation near-fractional melts.

Spiegelman and Elliott (1993) explained how local-element fractionation might operate in MORBs by considering melt transport, whereby nuclides travel at speeds in the melt according to their $\mathrm{D}_{\mathrm{Bulk}}$ and mantle porosity $\phi$ (the chromatographic effect). It is also possible to explain local-element fractionation by considering mantle upwelling rate alone (Elliott, 1997; McKenzie, 1985). For example, net-element fractionation assumes no ingrowth of $\left({ }^{230} \mathrm{Th} /{ }^{232} \mathrm{Th}\right)$ in the mantle residue (Elliott, 1997), while local-element fractionation can be viewed as assuming complete ingrowth, in which the residual mantle returns to secular equilibrium at each melting increment. Complete ingrowth occurs when melting occurs over a timescale longer than the "critical extraction time" provided by Spiegelman and Elliott (1993), who parametrized this threshold according to spreading rate and porosity. They find that MOR spreading rates translate into upwelling rates that reasonably fall in between these two end-member scenarios (Elliott, 1997; Spiegelman \& Elliott, 1993). Similar to Spiegelman and Elliott (1993), we can calculate a porosity-independent "critical melt extraction length-scale" by comparing the time it takes upwelling mantle to traverse the melting region to the time required to return to secular equilibrium $\left(\sim 5-6\right.$ half-lives of $\left.{ }^{230} \mathrm{Th}\right)$. Ultraslow- and slow-spreading rates have very small critical melt extraction length scales of $\sim 0.4-2 \mathrm{kbar}$, while intermediate- and fast-spreading ridges require $\sim 3-5$ and $\sim 6 \mathrm{kbar}$ of melting, respectively (Figure 3 ). Melting is expected to occur over larger intervals than these critical melt extraction length scale (red lines and shaded region in Figure 3); therefore, all upwelling and melting mantles (histograms in Figure 3) experience some-yet variable-extents of mantle ingrowth.

Even though our end-member approach does not directly incorporate upwelling velocity, it is useful because the unknowns and errors in $U$ and Th partition coefficients lead to larger differences in calculating ${ }^{230} \mathrm{Th}$ excesses than errors associated with the spreading rate dependence. For example, Spiegelman and Elliott (1993) calculated a melt $\left({ }^{230} \mathrm{Th}\right) /\left({ }^{238} \mathrm{U}\right)=1.13$ using their equilibrium porous flow melt transport model for a mantle upwelling at $5 \mathrm{~cm} / \mathrm{yr}$ assuming $\phi=0.5 \%, \mathrm{D}_{\text {Bulk }}^{\mathrm{U}}=0.0086, \mathrm{D}_{\text {Bulk }}^{\mathrm{Th}}=0.0065$, and $\mathrm{D}_{\text {Bulk }}^{\mathrm{U}} / \mathrm{D}_{\text {Bulk }}^{\text {Th }}=1.32$ (their Figure 3). Assuming the same $\phi$ and Ds, our local-element fractionation end-member predicts a maximum $\left({ }^{230} \mathrm{Th}\right) /\left({ }^{238} \mathrm{U}\right)=1.18$ (Equation $\mathrm{S} 8$ in the supporting information). While the lower $\left({ }^{230} \mathrm{Th}\right) /\left({ }^{238} \mathrm{U}\right)$ by 0.05 of melts of mantle upwelling at intermediate-spreading rates is significant (i.e., could be the difference between requiring residual garnet or not), the 0.05 offset is within the error of the Ds. The error on $\mathrm{D}_{\text {Bulk }}^{\mathrm{U}}$ itself is $\sim 0.0005-0.001$ (Beattie, 1993a; Elkins et al., 2008; Salters \& Longhi, 1999). If we reduce $\mathrm{D}_{\text {Bulk }}^{\mathrm{U}}$ from 0.0086 to 0.0080 , our simplified local-element fractionation model predicts a maximum $\left({ }^{230} \mathrm{Th}\right) /\left({ }^{238} \mathrm{U}\right)=1.13$ - the same value as if we had directly taken into account a mantle upwelling velocity of $5 \mathrm{~cm} / \mathrm{yr}$. We assume instantaneous melt velocities for all extracted melts, as is common for many U-series melting models (see Elliott \& Spiegelman, 2014), so both near-fractional and pooled near-fractional melts retain their maximum ${ }^{230} \mathrm{Th}$ excesses under both local-element fractionation and net-element fractionation. Slower melt velocities would act to reduce ${ }^{230}$ Th excesses.

\section{Results}

We first quantify garnet-lherzolite melting as a function of the mantle temperature, composition, velocity, and porosity conditions required for melting in the garnet field in section 3.1. Second, we define the distinct major, trace, and ${ }^{230} \mathrm{Th}$ excesses compositions of garnet-lherzolite melts and the effect that garnet-lherzolite melting has on the composition of all near-fractional and pooled melts produced along a melting path (section 3.2). Last, we use Petrogen to invert for mantle trace element source compositions consistent with MORB crustal thickness (section 3.3). 

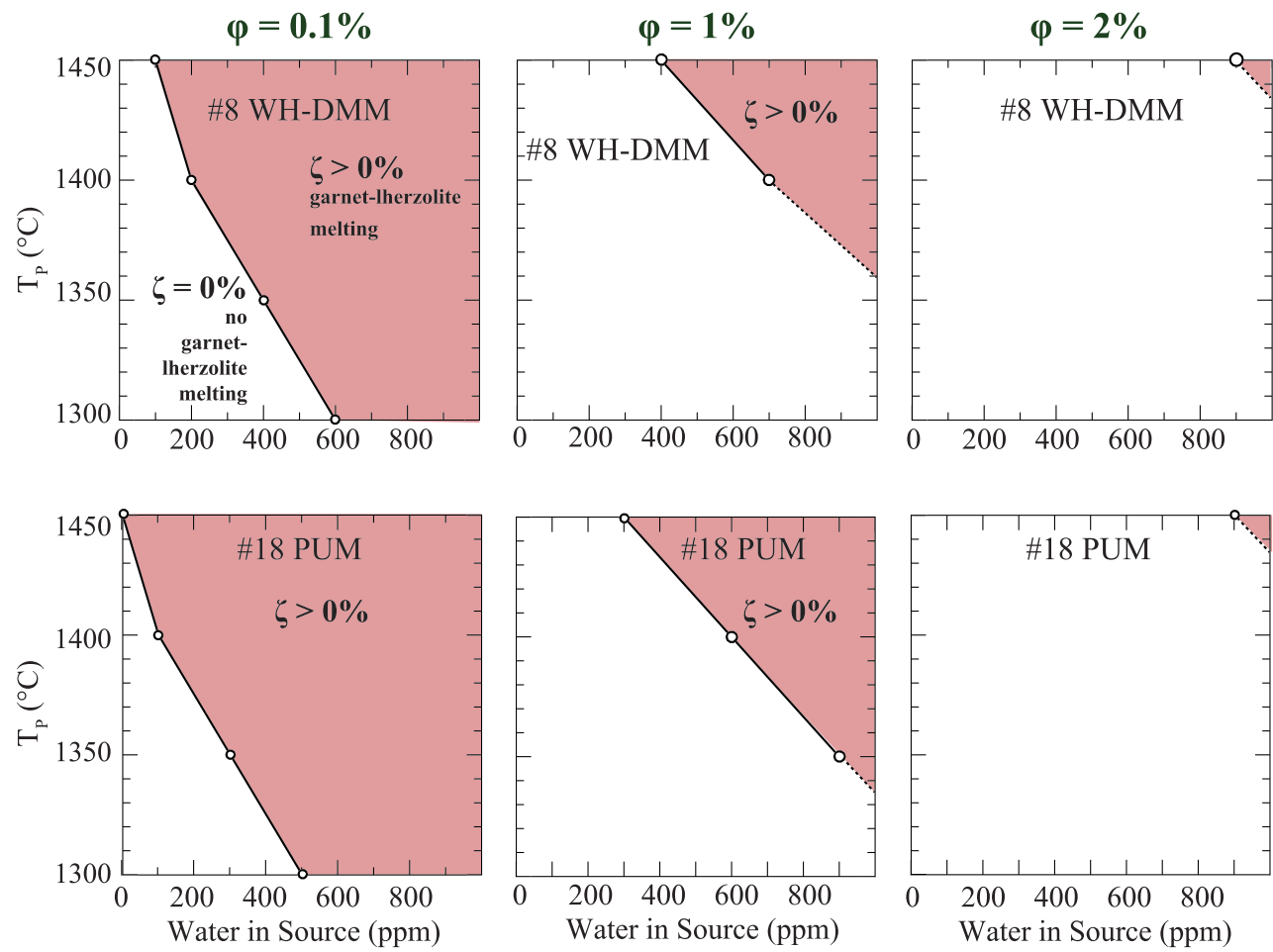

Figure 4. Plots of garnet-lherzolite melting as a function of $T_{\mathrm{P}}$ and source water content for different mantle porosities $\phi$ and bulk compositions (top row is DMM, and bottom row is PUM). Extraction of garnet-lherzolite melts requires high water contents, high $T_{\mathrm{P}}$, and small $\phi=0.1 \%$. Whether or not garnet-peridotite melting occurs $(\zeta>0 \%)$ is independent of spreading rate.

\subsection{Conditions Required for Garnet-Peridotite Melting ( $\zeta>0 \%)$}

Overall, our calculations show that garnet-lherzolite melting requires hot $T_{\mathrm{P}}$, lower $\phi$, and/or higher water contents (Figures 4, S2, and 5 and section S12). Under the same conditions, PUM and WH-DMM have similar likelihoods of melting in the garnet field (Figure 4 and S2), but PUM produces up to $~ 5 \%$ more garnet-equilibrated melts (Figure S2). In detail, garnet-lherzolite melting follows five fundamental principles:

1. Under most mantle conditions tested, melting initiates in the spinel, not the garnet-stability field

(Figures 4, S2, and 5). When melting does initiate in the garnet field, melt fractions do not exceed a
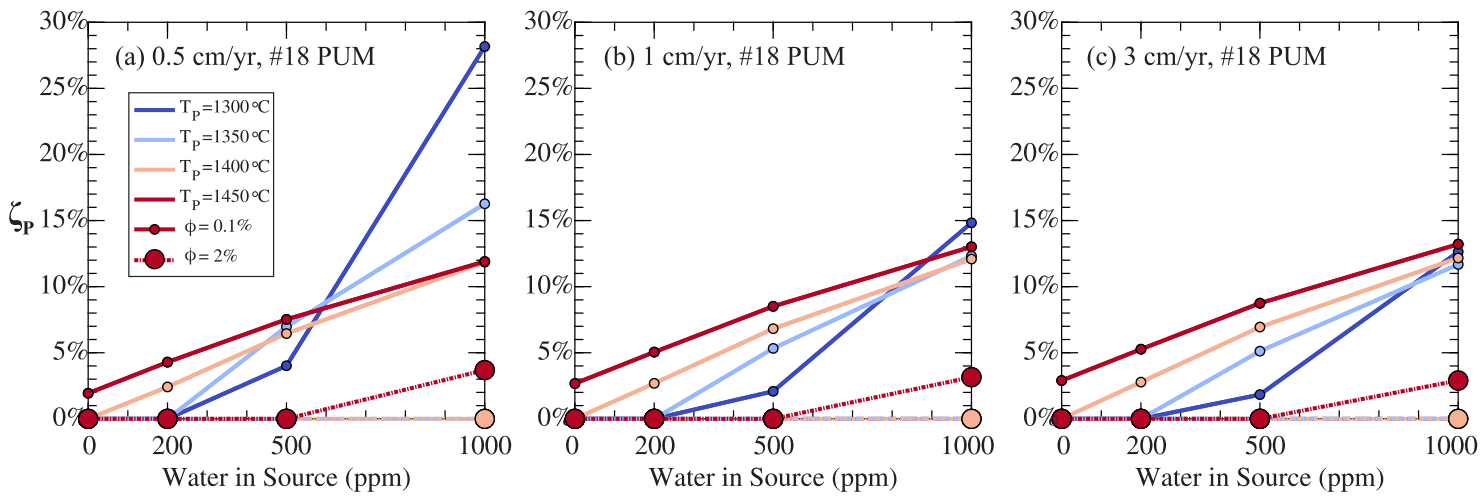

Figure 5. Garnet-lherzolite melt fractions in pooled melts $\left(\zeta_{\mathrm{P}}\right)$ as a function of source water content, $T_{\mathrm{P}}$, and mantle porosity $(\phi)$ for $(\mathrm{a}-\mathrm{c})$ three different half spreading rates. $\zeta_{\mathrm{P}}>10 \%$ require hot mantle potential temperatures, high water contents, and low $\phi=0.1 \%$. The coldest $T_{\mathrm{P}}$, however, lead to the largest $\zeta_{\mathrm{P}}>20 \%$ when spreading rates are ultraslow, water contents are very high, and $\phi=0.1 \%$ (panel a). 

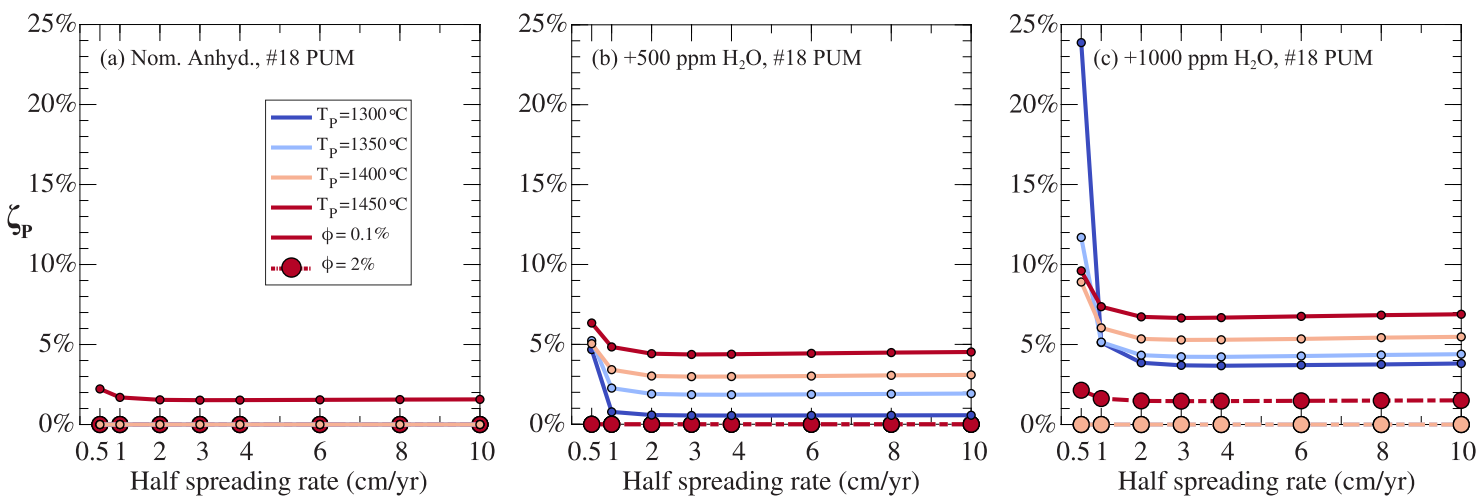

Figure 6. Garnet-lherzolite melt fractions in pooled melts $\left(\zeta_{\mathrm{P}}\right)$ as a function of spreading rate, $T_{\mathrm{P}}$, and mantle porosity $(\phi)$ for $(\mathrm{a}-\mathrm{c})$ three different source water contents. The largest $\zeta_{\mathrm{P}}$ occur at ultraslow-spreading rates when mantle sources have high water contents and cold $T_{\mathrm{P}}$ (panel c). Melting initiates deep due to high water contents but also stops melting deep due to cold $T_{\mathrm{P}}$ and a thick conductive lithosphere.

few percent before the mantle ascends into the spinel-stability field. Therefore, if $\phi$ is $>\sim 1 \%$, near-fractional garnet-lherzolite melts are not preserved unless the source is hot $\left(T_{\mathrm{P}}=1450^{\circ} \mathrm{C}\right)$, enriched, and damp ( $>500 \mathrm{ppm}$ water) (Figures 4, S2, and 5). Spreading rate does not influence $\zeta$ at percent-level values of $\phi$ (Figure 6).

2. Extraction of garnet-lherzolite melts $(\zeta>0 \%)$ under nominally anhydrous conditions requires hot $\left(T_{\mathrm{P}}\right.$ $>1400^{\circ} \mathrm{C}$ ) highly alkali-enriched sources with $\mathrm{NaK} \#>0.15$ (Figure S2). Garnet-lherzolite melting occurs in these compositions because they can have lower solidi in the garnet field compared to the spinel field (Figure S2c). The pooled melts generated under these conditions, however, have low proportions of garnet-lherzolite melts $\left(\zeta_{\mathrm{P}}<10 \%\right)$, but $\zeta_{\mathrm{P}}$ can increase to $20 \%$ with extremely high $\mathrm{K}_{2} \mathrm{O}(>0.25 \mathrm{wt} \%)$ bulk compositions. If we restrict sources to have $\mathrm{NaK} \#<0.15, \zeta_{\mathrm{P}}$ reaches a maximum of $\sim 5 \%$ (Figures 5 and 6 ).

3. Reducing porosity to $\phi=0.1 \%$ increases the likelihood of extracting garnet-lherzolite melts $(\zeta>0 \%)$ (Figures 4, S2, and 5). At $T_{\mathrm{P}}=1450^{\circ} \mathrm{C}$ under nominally anhydrous conditions, mantles with $\mathrm{NaK} \#<0.15$ have $\zeta_{\mathrm{P}}<6 \%$ while the highest $\mathrm{NaK} \#>0.15$ mantle have $\zeta_{\mathrm{P}}=6-12 \%$ (Figure S2). At $T_{\mathrm{P}}=1400^{\circ} \mathrm{C}$ and nominally anhydrous conditions, only moderately ( $\mathrm{NaK \#}>\sim 0.1$ ) to highly $(\mathrm{NaK} \#>0.15)$ enriched mantle compositions generate garnet-lherzolite melts with pooled $\zeta_{\mathrm{P}}=1-2 \%$ and $\zeta_{\mathrm{P}}=2-9 \%$, respectively (Figure $\mathrm{S} 2$ ).

4. Increasing water concentrations in the source causes melting to initiate deeper, increasing $\zeta_{\mathrm{P}}$ to a maximum $\sim 11 \%$ at $T_{\mathrm{P}}=1450^{\circ} \mathrm{C}$ for the mantle bulk compositions that stabilize garnet (Figures S2 and 5). When $\phi=0.1 \%$, source water contents $\geq 500-700 \mathrm{ppm}$ are necessary for garnet-lherzolite melting to occur at all $T_{\mathrm{P}}$ for all mantle compositions (Figure 4). Changing the melt productivity when melting occurs at temperatures below the anhydrous solidus, that is, $X_{\frac{\mathrm{d}}{\mathrm{dP}}}$, does not change these systematics and does not influence $\zeta$ at these low $\phi$ values.

5. Counterintuitively, pooled melts with the largest garnet-equilibrated melt fractions of $\zeta_{\mathrm{P}}>20 \%$ occur in the coldest $T_{\mathrm{P}} \leq 1350^{\circ} \mathrm{C}$ and wettest $\left(\sim 1,000 \mathrm{ppm} \mathrm{H}_{2} \mathrm{O}\right)$ mantle upwelling at ultraslow-spreading ridges $(0.5 \mathrm{~cm} / \mathrm{yr})$, provided that mantle porosity is very low $(\phi=0.1 \%)$ (Figures S2d, 5a, and 6). For example, pooled melts can be composed of over $30 \%$ garnet-equilibrated melt $\left(\zeta_{\mathrm{P}}>30 \%\right)$ for a very wet PUM source with $1,000 \mathrm{ppm} \mathrm{H}_{2} \mathrm{O}$ at $1300^{\circ} \mathrm{C}$ (Figure 5a). At a warmer $T_{\mathrm{P}}$ of $1350^{\circ} \mathrm{C}, \zeta_{\mathrm{P}}$ decreases but it is still greater than in hotter mantles (Figure 5a). This special cold, wet, ultraslow regime occurs because under these conditions the mantle starts melting in the garnet field at all $T_{\mathrm{P}}$, but the combination of ultraslow-spreading and cold mantle generates thick lithosphere that suppresses melting in the spinel and plagioclase fields to a greater extent than ultraslow-spreading alone. It is this extremely deep cessation of melting ( $\sim 10-11 \mathrm{kbar})$ that leads to high $\zeta_{\mathrm{P}}$ for all mantle bulk compositions.

\subsection{Signatures of Garnet-Lherzolite Melts}

\subsubsection{Major Element Signatures of Garnet-Lherzolite Melting}

The compositions of near-fractional melts are discontinuous across the garnet to spinel transition and increase in $\mathrm{Na}_{2} \mathrm{O}$ and $\mathrm{Al}_{2} \mathrm{O}_{3}$ content by a few wt\% and decrease in $\mathrm{MgO}$ and $\mathrm{FeO}$ by a few wt\% 
(a)
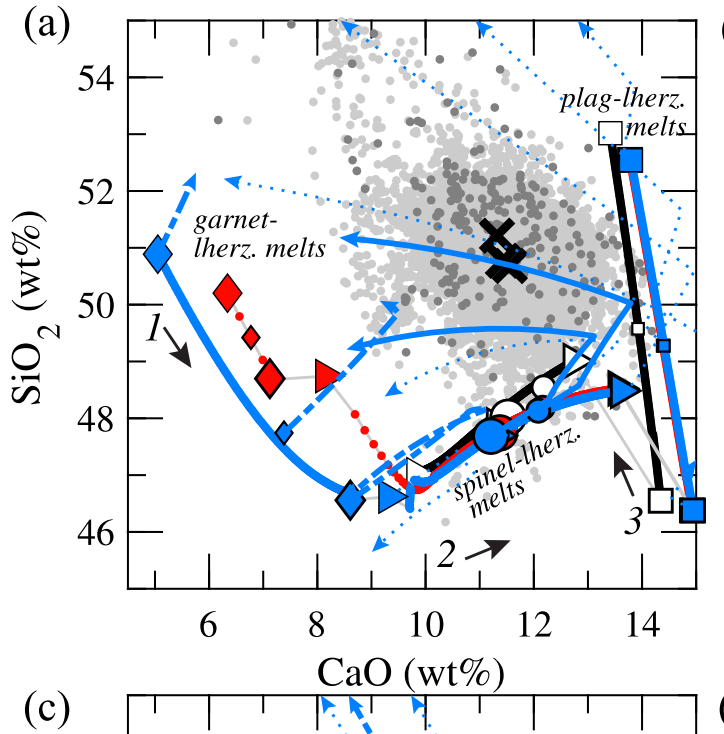

(c)

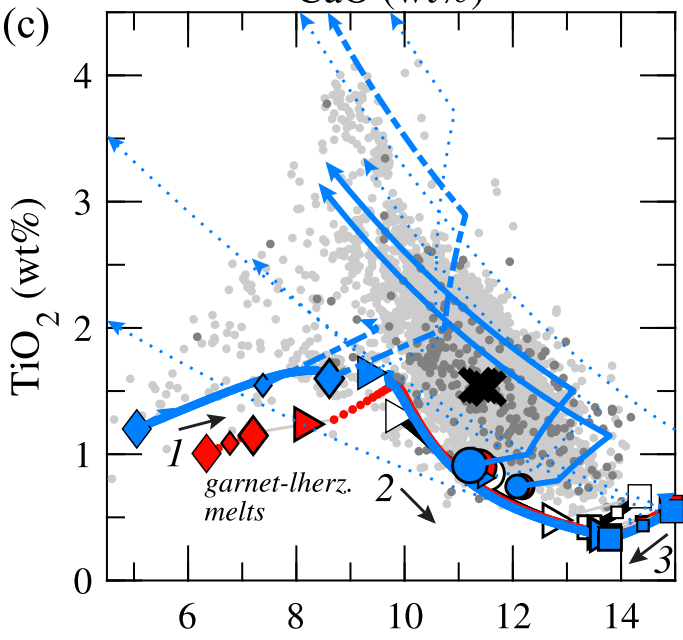

(e)

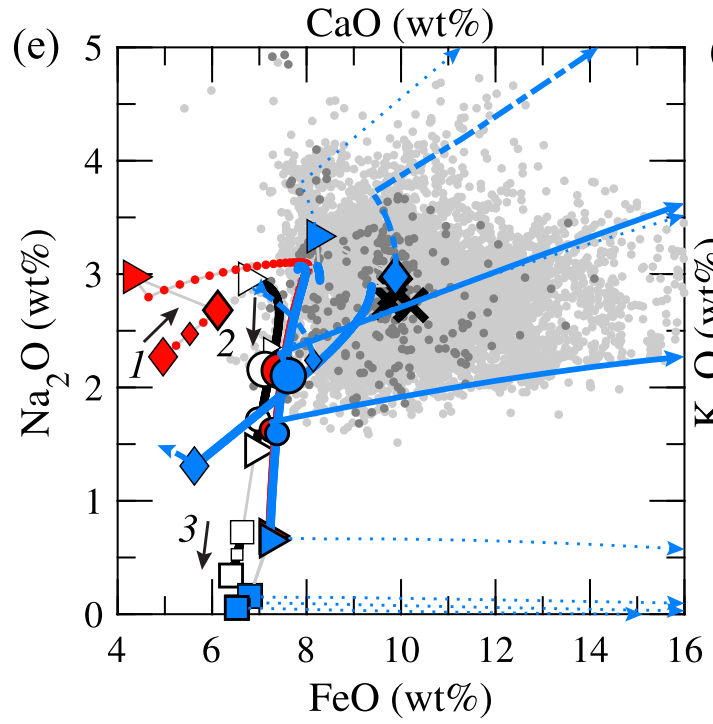

(b)
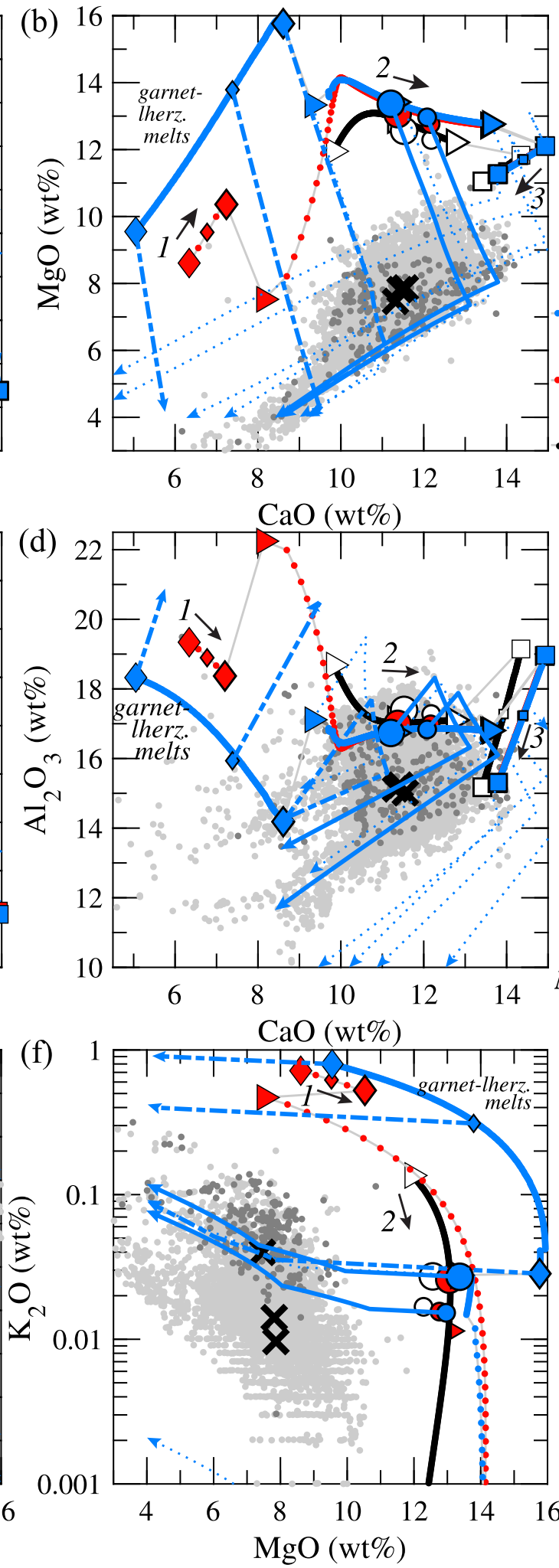

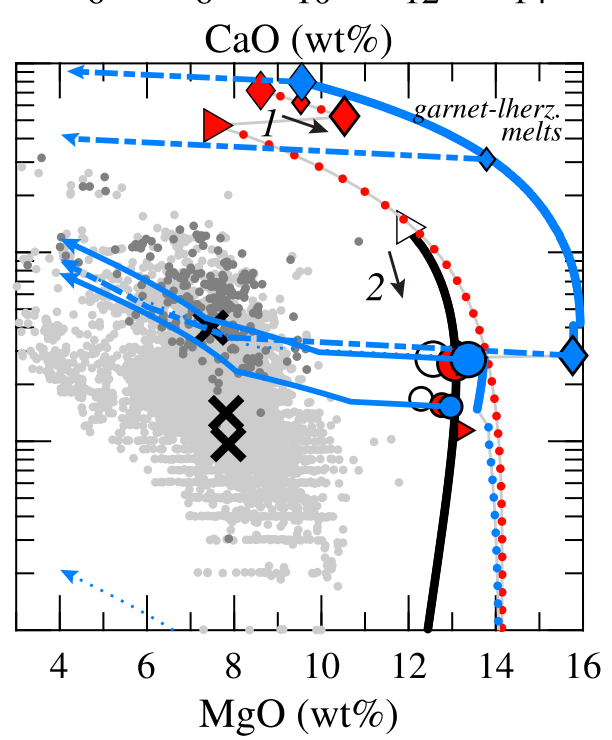

PETROGEN

MODEL MELTS

3 models with:

$\mathrm{T}_{\mathrm{P}}=1450^{\circ} \mathrm{C}$

PUM source

$1 \mathrm{~cm} / \mathrm{yr}$

but variable $\phi$ and source water content:

$0-\phi=0.1 \% 500 \mathrm{ppm}$ $\zeta_{\mathrm{P}}=9 \%$

- $\phi=0.1 \%$ NomAnhyd $\xi_{\mathrm{P}}=2 \%$

$\cdot \circ-\phi=2 \%$ NomAnhyd

Model primary melts

Pooled melts

Full pool

OOn-axis pool

Near-fractional melts

garnet $\diamond_{\cdots}^{1 \text { st }}$ avg. last

spinel $^{1 \text { st }} \stackrel{\text { avg. }}{\text { last }}$

plag 1 st $\stackrel{\text { avg. last }}{\square}$

$\rightarrow$ Schematic direction

of near-frac. melting

$1=$ garnet lherz.

$2=$ spinel lherz.

$3=$ plagioclase lher .

Model fractionated melts

(shown for blue model)

$\longrightarrow$ pooled

$\rightarrow$ near-fractional

garnet

$\rightarrow$ near-fractional spinel \& plag.

DATA

- all MORB

all E-MORB as

- $\mathrm{La} / \mathrm{Sm}_{\mathrm{PUM}}>1.5$

$\boldsymbol{X}^{\text {avg. E-, N-, }}$

Figure 7. (a-f) Major element compositions of MORB (light and dark gray circles) compared to three different models of melting a PUM source (in black, red, and blue) that have different amounts of garnet-lherzolite melting (i.e., garnet-lherzolite melt fractions of $\zeta_{\mathrm{P}}$ from $0-9 \%$ ). Models all assume $T_{\mathrm{P}}=1450^{\circ} \mathrm{C}$ and a half spreading rate of $1 \mathrm{~cm} / \mathrm{yr}$, but with different mantle porosity $(\phi)$ and source water contents. Primary near-fractional melts and pooled melts are shown for all three models. Low pressure ( $1 \mathrm{~atm})$ fractional crystallization paths to $4 \mathrm{wt} \% \mathrm{MgO}$ are shown for the blue model $\left(\zeta_{\mathrm{P}}=9 \%\right)$; fractional crystallization paths for the other two models mirror the paths shown. Arrows indicate direction of increasing melt extent. 


\section{(a)}

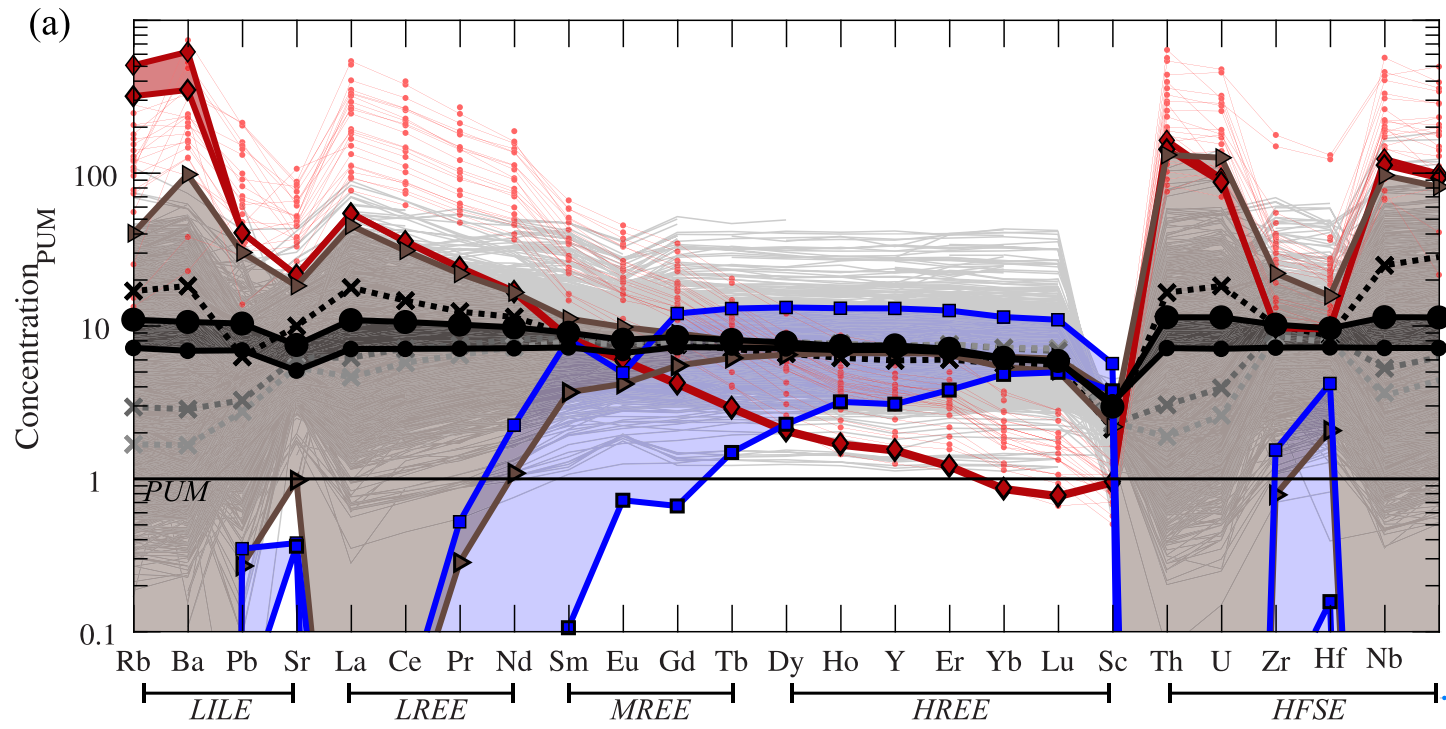

MODEL MELTS

Panel A) single model:

$\phi=0.1 \%$ NomAnhyd $\zeta_{\mathrm{P}}=2 \%$

Near-fractional melts

garnet

spinel

plag 1 last

Pooled melts

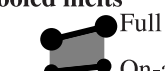

shaded regions are

intermedite melts

Panels B\&C) 3 models $w /$ :

$\mathrm{T}_{\mathrm{P}}=1450^{\circ} \mathrm{C}$

PUM source, $1 \mathrm{~cm} / \mathrm{yr}$

but variable $\phi$ and

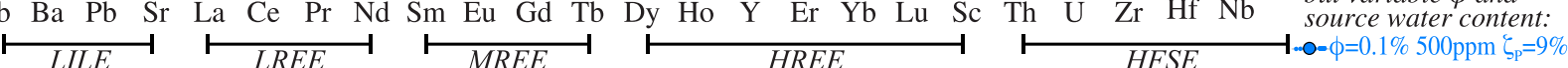

$0=0.1 \%$ NomAnhyd $\zeta_{\mathrm{p}}=2 \%$
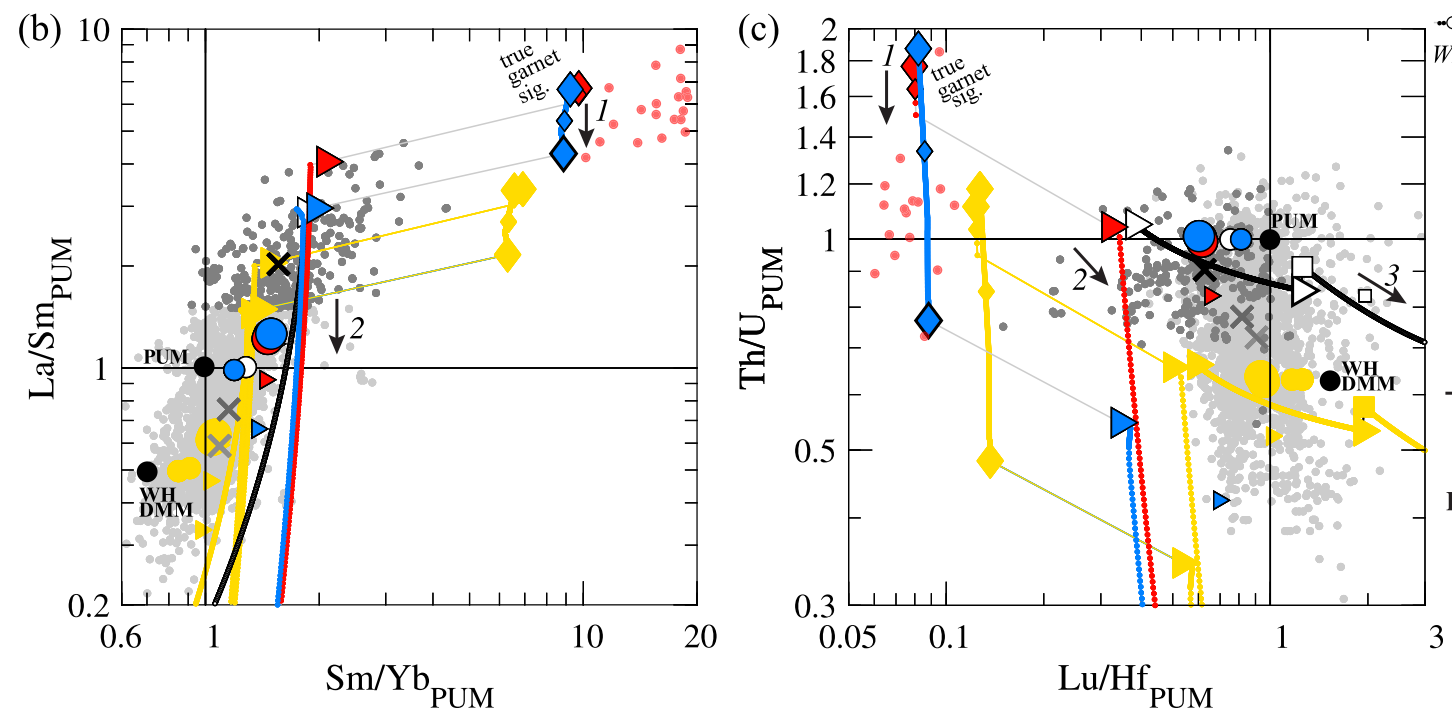

- $-\phi=2 \%$ NomAnhyd $\zeta_{\mathrm{P}}=0 \%$

WH DMM trace source in yellow

Pooled melts

OFull OOn-axis

Near-fractional melts

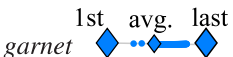

spinel ${ }^{1 \mathrm{st}}$ avg. Jast

plag 1st avg. last

$\rightarrow$ Schematic direction of

l=garnet ther

$1=$ garnet ther
$2=$ spinel lherz

DATA $2=$ spinel therz.
$3=$ plag lherz.

- or - All MORB - E-MORB

- - $\times$ - or $\mathbf{x}$ Avg. E-MORB

- $\times$ - or X Avg. N-MORB

- or $\times$ Avg. D-MORB

$\rightarrow$ or SA Kimberlites

Figure 8. Trace element compositions of MORB compared to Petrogen model melts. (a) Spider diagram showing the near-fractional and pooled melts of the $\zeta_{\mathrm{P}}=2 \%$ model (red model in $\mathrm{b}$ and c) and in Figure 7). All melts are fractionally crystallized to $8 \mathrm{wt} \% \mathrm{MgO}$. Shaded colored regions show the intermediate near-fractional melts by field. (b and c) Trace element ratio-ratio compositions of MORB compared to the same three models in Figure 7 that have different amounts of garnet-lherzolite melting ( $\zeta_{\mathrm{P}}$ from 0-9\%). Models all assume the same PUM source and $T_{\mathrm{P}}=1450^{\circ} \mathrm{C}$ and a half spreading rate of $1 \mathrm{~cm} / \mathrm{yr}$, but different mantle porosity $(\phi)$ and source water contents. Modeled near-fractional melts extend beyond the lowest values shown on the vertical axes. Melts assuming a DMM trace source show in yellow for comparison. MORB and South African (SA) kimberlite data same as in Figure 1.

(Figures $7 \mathrm{~b}$ and $7 \mathrm{~d}-7 \mathrm{f}$ ). Pooled melt compositions are also influenced; pooled melts with a nonzero contribution from garnet lherzolite $\left(\zeta_{\mathrm{P}}>0 \%\right)$ are lower in $\mathrm{SiO}_{2}, \mathrm{Al}_{2} \mathrm{O}_{3}$, and higher in $\mathrm{FeO}$ and $\mathrm{MgO}$ than pooled melts with no contribution from garnet lherzolite $\left(\zeta_{\mathrm{P}}=0 \%\right)$. In detail, there are four dominant major element characteristics of garnet-lherzolite melts (Figure 7):

1. Melts of garnet lherzolite are low in $\mathrm{CaO}(<9 \mathrm{wt} \%)$ and are distinguished in all Harker diagrams with $\mathrm{CaO}$ as one axis (Figures $7 \mathrm{a}-7 \mathrm{~d}$ ). Garnet-lherzolite melts only have higher $\mathrm{CaO}$ contents $>9 \mathrm{wt} \%$ if the extent of melting of a garnet-peridotite reaches $\sim F=10 \%$ (Walter, 1998), as may be for ocean island basalts and continental basalts. Melts of opx-free garnet peridotites may also have slightly higher $\mathrm{CaO}$ contents, but more experiments are needed to confirm this effect.

2. Garnet-lherzolite melts are necessarily high pressure and so carry with them the high-pressure signature of being more olivine-rich (i.e., high $\mathrm{MgO}$ and $\mathrm{FeO}$ and low $\mathrm{SiO}_{2}$ contents in Figures 7a, 7b, 7e, and 7f). 

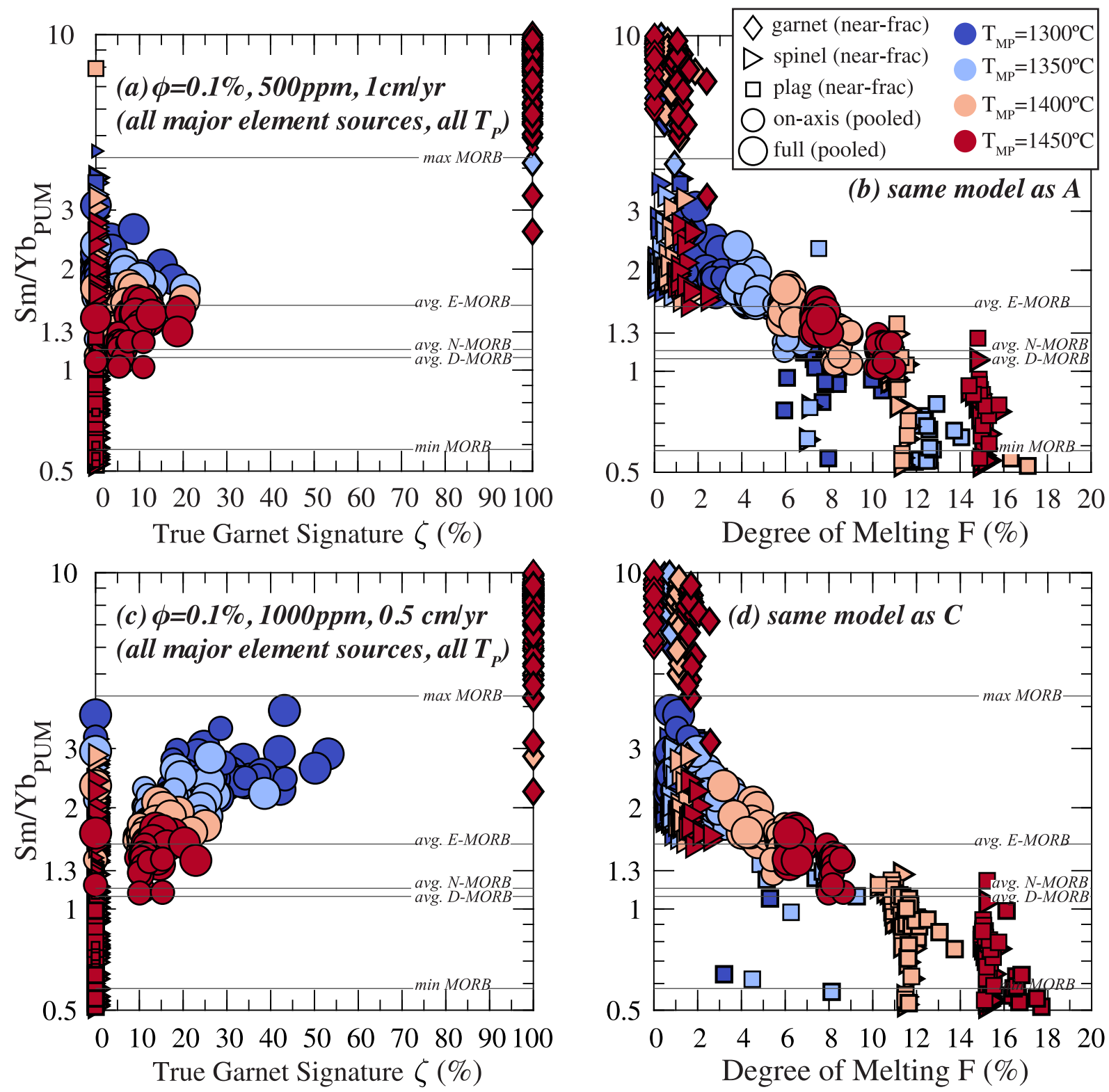

Figure 9. MORB (gray horizontal lines) compared to modeled $\mathrm{Sm} / \mathrm{Yb}$ in near-fractional and pooled melts as a function of garnet-lherzolite melt fractions ( $\zeta$ ) (a and c) and degree of melting, F, (b and d) for all 31 mantle bulk compositions tested. The top row shows results for melting conditions that lead to garnet-lherzolite melting for most bulk compositions with a $1 \mathrm{~cm} / \mathrm{yr}$ half spreading rate $(\phi=0.1 \%, 500 \mathrm{ppm}$ water in the source). The bottom row shows results for the ultraslow case with high garnet-lherzolite melt fractions $(\phi=0.1 \%, 1,000 \mathrm{ppm}$ water). Stronger garnet signatures (e.g., high Sm/Yb) do not correlate with higher garnet fractions $(\zeta)$ unless $\zeta$ is $>\sim 20 \%$ (a and c) but do inversely correlate with increasing degrees of melting (b and d). Only the first and last near-fractional melts in each stability field along a single melting path are plotted. All models assume a PUM trace element source.

3. Garnet-lherzolite melts are extremely variable in $\mathrm{SiO}_{2}$. $\mathrm{SiO}_{2}$ increases with increasing pressures of melting (Figure 7a).

4. Garnet-lherzolite melts will be derived from more fertile mantle in the sense that subsequent melting only acts to deplete the mantle. This means that garnet-lherzolite melts will derive from mantle with higher NaK\#s. While this is always true in a decompressing system without garnet-lherzolite melting, if melt extraction does occur in the garnet-stability field, these initial melts will carry the signature of being lower-degree melts than subsequent melts (Figures 7e and 7f) and will also uniquely show trends of decreasing $\mathrm{NaK} \#$ with decreasing $\mathrm{SiO}_{2}$ content. 
5. Mantle conditions that typically result in some garnet-lherzolite melt extraction for all mantle bulk compositions tested ( $\phi=0.1 \%, 500 \mathrm{ppm}$ water) produce near-fractional garnet-field melts with a wide range of compositions that mirror the garnet major element signatures discussed above, and fill out the space to higher $\mathrm{SiO}_{2}$ and lower MgO contents (Figure S4).

\subsubsection{Trace Element Signatures of Garnet-Lherzolite Melting}

Near-fractional garnet-lherzolite melts with $\zeta_{n}=100 \%$ of the reference PUM source closely overlap kimberlites in their trace element signatures (Figure 8). Changing the trace element source composition shifts melts compositions relative to the shift made in the source (yellow models in Figures $8 \mathrm{~b}$ and $8 \mathrm{c}$ ). Near-fractional garnet-lherzolite melts have MREE/HREE (Sm/Yb) and HREE/HFSE ( $\mathrm{Lu} / \mathrm{Hf}$ ) compositions that form gaps with the compositions of subsequent near-fractional spinel- and plagioclase-field melts (Figures $8 \mathrm{~b}$ and $8 \mathrm{c}, x$ axis). By contrast, the LREE/MREE (La/Sm) and HFSE slope (Th/U) signatures of near-fractional garnetlherzolite melts, while distinct, are more continuous with spinel- and plagioclase-lherzolite near-fractional melts (Figures $8 \mathrm{~b}$ and $8 \mathrm{c}, y$ axis).

Variably pooled melts with small true garnet signatures $\zeta_{\mathrm{P}}>0 \%$ are indistinguishable from pooled melts without true garnet signatures $\left(\zeta_{\mathrm{P}}=0\right)$ (Figure 8). Instead, the efficiency of off-axis melt pooling and the magnitude of $\mathrm{D}_{\text {Bulk }}$ better determines if a pooled melt appears more or less garnet-like. Melts pooled from across the entire triangle-shaped melting regime have overall lower degrees of melting and stronger garnet signatures (big circles in Figures 8b and 8c) compared to narrowly pooled on-axis (column-shaped) melts (small circles in Figures $8 \mathrm{~b}$ and $8 \mathrm{c}$ ). This effect is more pronounced in ratio spaces with larger overall $\mathrm{D}_{\mathrm{Bulk}}$; for example, no pooled melt retains a $\mathrm{Th} / \mathrm{U}$ garnet signature, and only on-axis pooled melts retain a $\mathrm{La} / \mathrm{Sm}$ garnet signature-but all pooled melts retain weak $\mathrm{Sm} / \mathrm{Yb}$ and $\mathrm{Lu} / \mathrm{Hf}$ garnet signatures relative to their trace element source composition (Figures $8 \mathrm{~b}$ and $8 \mathrm{c}$ ).

When we explore different major and trace element mantle bulk compositions under conditions that result in some garnet-lherzolite melt extraction for all mantle bulk compositions tested (e.g., $\phi=0.1 \%, 500 \mathrm{ppm}$ water), we produce near-fractional garnet melts with a wide range of trace element compositions that reflect different mineral modes, extent of melting, and the trace element source composition (Figure S5).

3.2.2.1. Relationship Between $\phi$ and Trace Element Signatures in Near-Fractional Melts Mantle porosity, $\phi$, strongly influences the maximum magnitude and also the trajectory of the near-fractional melting paths of the most incompatible trace elements (e.g., LREE and HFSE) (Equation S15 in the supporting information can be applied to all trace elements). For example, smaller porosity ( $\phi=0.1 \%$, blue and red lines in Figure 8 ) more quickly depletes residues and creates steeper melting paths compared to larger porosity ( $\phi=2 \%$, black lines in Figure 8$)$.

3.2.2.2. Relationship Between $\zeta_{P}$ and Trace Element Garnet Signatures in Pooled Melts

The strength of a major or trace element garnet signature (e.g., high $\mathrm{Sm} / \mathrm{Yb}$ ) in a pooled mantle melt does not correlate with the amount of melt derived from garnet peridotite $\left(\zeta_{\mathrm{P}}\right)$ unless $\zeta_{\mathrm{P}}$ is $>\sim 20 \%$ (Figures 9a and 9c). Only ultraslow-spreading ridges have the potential to produce pooled melts with $\zeta_{\mathrm{P}}>\sim 20 \%$ (see section 5).

In all cases, such as when $\zeta_{\mathrm{P}}$ is $<\sim 20 \%$, the strength of apparent garnet trace element signatures in pooled melts is inversely correlated with their overall degrees of melting (Figures $9 \mathrm{~b}$ and $9 \mathrm{~d}$ ). Mantle conditions that lead to garnet-lherzolite melting $\left(\zeta_{\mathrm{P}}>0\right.$, high $T_{\mathrm{P}}$, enriched source compositions, and high source water contents) also lead to overall higher degrees of melting and small garnet trace element signatures in their pooled melts (low $\mathrm{La} / \mathrm{Sm}$ and low $\mathrm{Sm} / \mathrm{Yb}$ ). These pooled melts have trace element compositions that more closely resemble their sources (Figures 9a and 9c). In contrast, mantle conditions with lower overall degrees of melting that lead to no garnet-lherzolite melting ( $\zeta_{\mathrm{P}}=0$, lower $T_{\mathrm{P}}$, less enriched source compositions, and low source water contents) tend to have the strongest apparent garnet signatures (Figures 9b and 9d). In contrast, and discussed below, $\zeta_{\mathrm{P}}$ does positively correlate with ${ }^{230} \mathrm{Th}$ excesses, but only under local-element fractionation conditions.

3.2.3. $\left({ }^{230} \mathrm{Th} /{ }^{238} \mathrm{U}\right)$

${ }^{230}$ Th excesses in our model depend on $\mathrm{D}_{\text {Bulk }}^{\text {Th }}$, $\mathrm{D}_{\text {Bulk }}^{\mathrm{U}}$, mantle porosity $\phi$, and degree of melting, $F$ (Figure 10). $\mathrm{D}_{\text {Bulk }}^{\mathrm{Th}}$ and $\mathrm{D}_{\text {Bulk }}^{\mathrm{U}}$ are influenced by the pressure of melting, the mantle bulk composition through the mantle mode, and $F$ through its influence on the residual mantle mode. $F$ is also influenced by $T_{\mathrm{P}}$ and water content. Below we report the net-element fractionation and local-element fractionation ${ }^{230} \mathrm{Th}$ excesses produced by melting 31 nominally anhydrous mantle bulk compositions from $T_{\mathrm{P}}=1300-1450^{\circ} \mathrm{C}$ at a $1 \mathrm{~cm} / \mathrm{yr}$ half 

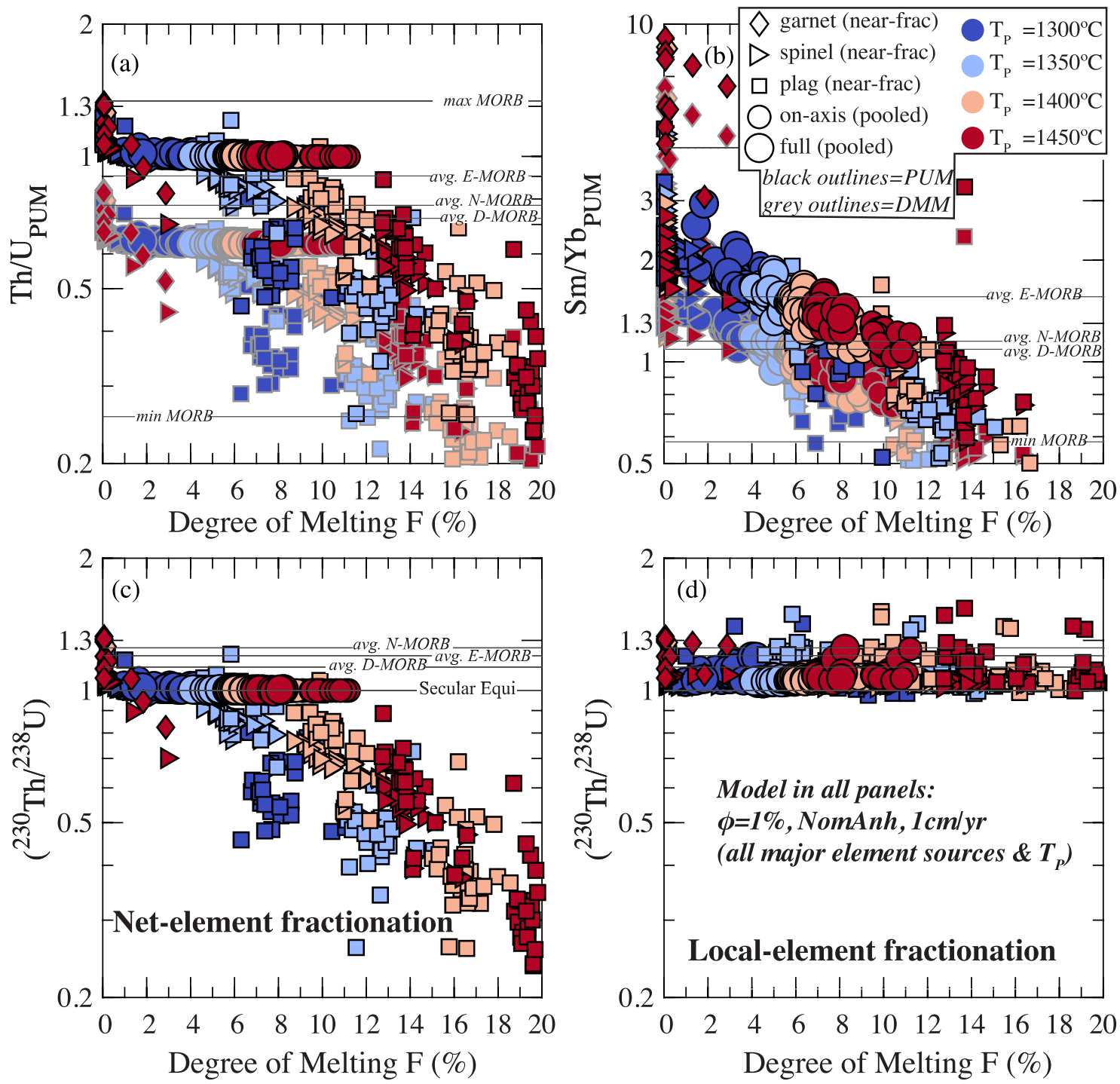

Figure 10. MORB (gray horizontal lines) compared to modeled Th/U (panel a), Sm/Yb (panel b), and $\left({ }^{230} \mathrm{Th} /{ }^{238} \mathrm{U}\right.$ ) (panels c and d) as a function of degree of melting of all 31 mantle bulk compositions tested. Modeled mantle conditions do not lead to garnet-lherzolite melting except for five bulk compositions with $T_{\mathrm{P}}=1450^{\circ} \mathrm{C}$ and one at $T_{\mathrm{P}}=1400^{\circ} \mathrm{C}$ (in diamonds). Panels (a) and (b) show garnet signatures assuming a PUM trace element source (black outline) and a Workman and Hart (2005) DMM trace element source (gray outline). Source composition does not influence $\left({ }^{230} \mathrm{Th} /{ }^{238} \mathrm{U}\right)$ (panels c and d). Only the first and last near-fractional melts in each stability field along a single melting path are plotted.

spreading rate assuming $\phi=0.1 \%$ and $\phi=1 \%$ (unless otherwise noted). For these models, melting in the garnet field only occurs with $\phi=0.1 \%$, more enriched bulk compositions, and $T_{\mathrm{P}}=\sim 1450^{\circ} \mathrm{C}$.

3.2.3.1. Net-Element Fractionation (Onset of Melting, Channelization, and Fast

Upwelling Mantles)

First near-fractional garnet-lherzolite melts have $\left({ }^{230} \mathrm{Th}\right) /\left({ }^{238} \mathrm{U}\right)$ that range from $1.2-1.3$ when $\phi=1 \%$ (Figure 10c) and from 1.35-2 when $\phi=0.1 \%$. At high degrees of melting, near-fractional melts produce ${ }^{230}$ Th-deficits (Figure 10c) and the overall abundances of $U$ and Th in these depleted melts is very small. When garnet melting has previously occurred, all subsequent lower-pressure, higher-degree spinel and plagioclase near-fractional melts have ${ }^{230}$ Th-deficits (Figure 10c). However, when garnet-lherzolite melting does not occur, the first low-degree melts in the spinel or plagioclase fields have $\left({ }^{230} \mathrm{Th}\right) /\left({ }^{238} \mathrm{U}\right)$ that range in magnitude from $1.05-1.38$ for $\phi=1 \%$, and from 1.1-1.35 when $\phi=0.1 \%$. All pooled melts are at secular equilibrium with $\left({ }^{230} \mathrm{Th} /{ }^{238} \mathrm{U}\right)=1$ (Figure 10c). 

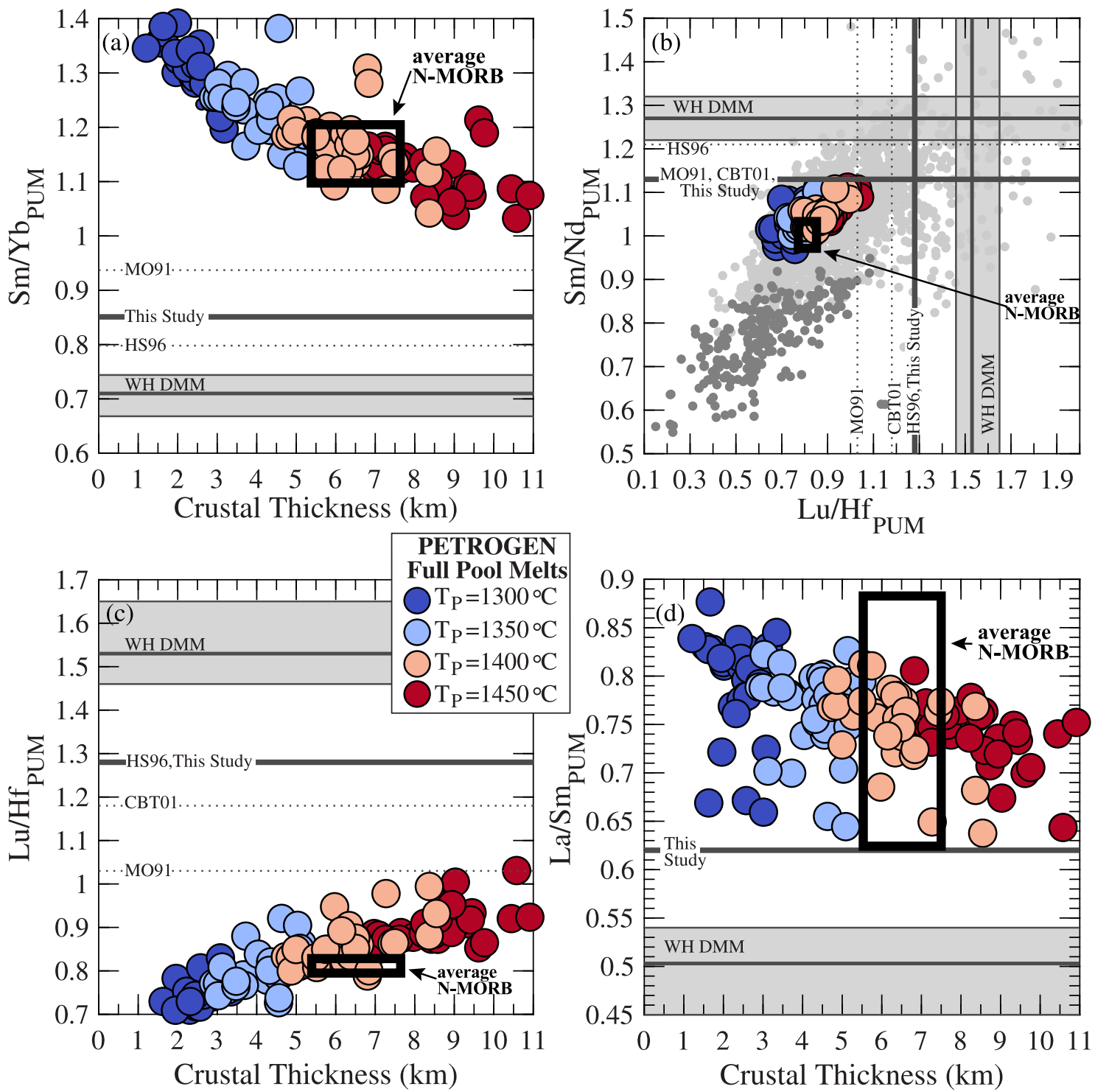

Figure 11. (a, c, and d) Plots showing MORB compared to modeled crustal thickness and garnet signatures in fully pooled melts with no garnet-lherzolite melts for all 31 bulk compositions tested. Panel (b) shows MORBs and same models in Sm/Nd-Lu/Hf ("Hafnium paradox") space after Salters and Hart (1989) and Chauvel and Blichert-Toft (2001). Horizontal and vertical lines indicate different DMM compositions. Black box indicates the 2-бaverage N-MORB garnet signatures. $T_{\mathrm{P}}=1350-1400^{\circ} \mathrm{C}$ models using the DMM trace source calculated here (this study) plot within the average N-MORB box. All models assume mantle porosity $\phi$ of $2 \%$, nominally anhydrous sources, and a half spreading rate of $3 \mathrm{~cm} / \mathrm{yr}$. MO91 = McKenzie and O'Nions (1991); HS96 = Hirschmann and Stolper (1996); CBT01 = Chauvel and Blichert-Toft (2001), and WH DMM = Workman and Hart (2005) (gray box is 2- $\sigma$ ). Light gray circles in panel (b) are MORBs and dark gray circles are E-MORBs from Gale et al. (2013).

\subsubsection{Local-Element Fractionation (Late Stage Melting, Equilibrium Porous Flow, and Slow Upwelling Mantles) \\ First near-fractional garnet-lherzolite melts generate the same $\left({ }^{230} \mathrm{Th}\right) /\left({ }^{238} \mathrm{U}\right)$ as in the net-element fractio- nation end-member: $1.2-1.3$ for $\phi=1 \%$ (Figure 10d) and 1.4-1.9 for $\phi=0.1 \%$. In this case, however, as extent of melting increases, ${ }^{230} \mathrm{Th}$ excesses remain high (Figure 10d). As melting moves into the spinel stability field, the ${ }^{230} \mathrm{Th}$ excesses of near-fractional melts decrease in response to the loss of garnet and to our pressure-dependent $\mathrm{D}_{\text {Bulk }}^{\mathrm{U}} / \mathrm{D}_{\text {Bulk }}^{\text {Th }}$ (Landwehr et al., 2001). The first melts of spinel peridotite have $\left({ }^{230} \mathrm{Th}\right) /$ $\left({ }^{238} \mathrm{U}\right)$ from $1.0-1.1$ for $\phi=1 \%$ and $\sim 1.2-1.4$ for $\phi=0.1 \%$. The final spinel-peridotite melts produced at shal- low pressures range from 1.0-1.1 $(\phi=1 \%)$ and $\sim 1.05-1.4(\phi=0.1 \%)$.}


As melting moves into the plagioclase-stability field, the $\left({ }^{230} \mathrm{Th}\right) /\left({ }^{238} \mathrm{U}\right)$ of near-fractional melts significantly increase to $1.0-1.5$ when $\phi=1 \%$ (Figure 10d) and 1.2-2.5 when $\phi=0.1 \%$. These high ${ }^{230}$ Th excesses occur in response to the plagioclase Ds of Sun et al. (2017) that were experimentally determined using a MORB. As melting continues and the mode of plagioclase decreases, $\left({ }^{230} \mathrm{Th}\right) /\left({ }^{238} \mathrm{U}\right)$ also decrease to 1 when $\phi=1 \%$ and 1-1.6 when $\phi=0.1 \%$. Note that in almost all cases we predict that there is some plagioclase remaining at the end of melting. Yet, while ${ }^{230} \mathrm{Th}$ excesses in high-degree near-fractional melts can be high under local-element fractionation conditions, any such high-degree melt from either the garnet-, spinel-, or plagioclase-field will be still be depleted in incompatible trace and minor elements, such as $\mathrm{Na}_{2} \mathrm{O}, \mathrm{K}_{2} \mathrm{O}$, $\mathrm{Sm} / \mathrm{Yb}$, and Th/U (Figures 10a and 10b).

Pooled melts have $\left({ }^{230} \mathrm{Th}\right) /\left({ }^{238} \mathrm{U}\right)$ that range from $\sim 1.05-1.2$ for $\phi=1 \%$ (Figure 10d) and $\sim 1.15-1.8$ for $\phi=0.1 \%$. These values reflect the integrated history of $\mathrm{D}_{\mathrm{Bulk}}^{\mathrm{U}} / \mathrm{D}_{\mathrm{Bulk}}^{\mathrm{Th}}$ over the melting column. Pooled melts will not be as depleted in incompatible trace and minor elements as high-degree near-fractional melts (Figures 10a and 10b).

\subsection{Trace Element Garnet Signatures and MORB Crustal Thickness}

Average N-MORB is, by definition, a pooled melt because it is a calculated average. Therefore, we can use Petrogen pooled melts to determine how N-MORB garnet signatures could be generated from the pooled melts of a single lithology that simultaneously produces $6.5 \mathrm{~km}$ of crust. To do this, we examine Petrogen pooled melts produced by melting the 31 major element mantle bulk compositions under nominally anhydrous conditions, a $3 \mathrm{~cm} / \mathrm{yr}$ half spreading rate, $\phi=2 \%$, and $T_{\mathrm{P}}=1300-1450^{\circ} \mathrm{C}$. All but three of the resulting pooled melts under these conditions have zero contribution from the garnet field. We compare Petrogen pooled melts and crustal thicknesses and find that matching average MORB crustal thickness of $6.5 \pm 1$ $\mathrm{km}$ requires $T_{\mathrm{P}}=1350-1400^{\circ} \mathrm{C}$ (Figures 11a, 11c, and 11d). We do not, however, match the trace element composition of N-MORBs when we use the Workman and Hart (2005) DMM source composition. Pooled melts are too low in $\mathrm{Sm} / \mathrm{Yb}, \mathrm{Lu} / \mathrm{Hf}, \mathrm{Sm} / \mathrm{Nd}$, and La/Sm (not shown in Figure 11).

To match both crustal thickness and trace element ratios, the N-MORB source needs across-the-board stronger initial garnet signatures that correspond to higher $\mathrm{Sm} / \mathrm{Yb}_{\mathrm{PUM}}=\sim 0.85$, lower $\mathrm{Lu} / \mathrm{Hf}$ PUM $=\sim 1.3$, lower $\mathrm{Sm} / \mathrm{Nd}_{\mathrm{PUM}}=\sim 1.1$, and higher $\mathrm{La} / \mathrm{Sm}_{\mathrm{PUM}}=\sim 0.62$. While these required DMM source compositions are not consistent with Workman and Hart (2005) DMM, they are consistent with other DMM source compositions (e.g., Chauvel \& Blichert-Toft, 2001; McKenzie \& O'Nions, 1991; Hirschmann \& Stolper, 1996, Figure 11). Thus, we can use the required ratios predicated by Petrogen and these other estimates of DMM to reconstruct a viable composition for the average N-MORB source. We use the Sm concentration of Hirschmann and Stolper (1996) and the Sm-Nd model age (e.g., the Sm/Nd ratio) of Chauvel and Blichert-Toft (2001) to calculate $\mathrm{Nd}, \mathrm{Yb}$, and La concentrations (0.866, 0.405, 0.314, respectively, in ppm). Because the required $\mathrm{Lu} / \mathrm{Hf}_{\mathrm{PUM}}$ ratio of 1.3 is close to the Hirschmann and Stolper (1996) ratio of 1.28, we use their ratio and values for $\mathrm{Lu}$ and $\mathrm{Hf}$ concentration. This potential DMM source matches the apparent garnet signatures in N-MORBs and MORB average crustal thickness (Figures 11a-11d) without involving garnet peridotite or garnet pyroxenite and is consistent with the DMM source used by Hirschmann and Stolper (1996).

\section{Origins of MORB Garnet Signatures by Melting Mantle Peridotite: Case Study From the EPR}

MORB garnet signatures, and compositional variability in general, can be produced by melting garnet-bearing sources and non-garnet-bearing sources in a wide variety of ways. These sources can also be peridotite or nonperidotite. Here in section 4, we discuss in detail the range of garnet signatures generated by melting mantle peridotite-with and without garnet-and compare these signatures in near-fractional and pooled melts to those found in local MORB trends. Then, in section 5, we discuss the constraints that must be obeyed for random mixtures of melts (i.e., mixtures not dictated by melt production proportions as are pooled melts) and/or nonperidotite sources to be viable sources of MORB garnet signatures.

To explore the range of garnet signatures produced by melting peridotite, we compare our modeled major and trace element compositions and ${ }^{230}$ Th excesses to the local trend along the $8-10^{\circ} \mathrm{N}$ East Pacific Rise (EPR) that includes the Siqueiros Transform. This well-studied section of the EPR is interesting to 
(a)
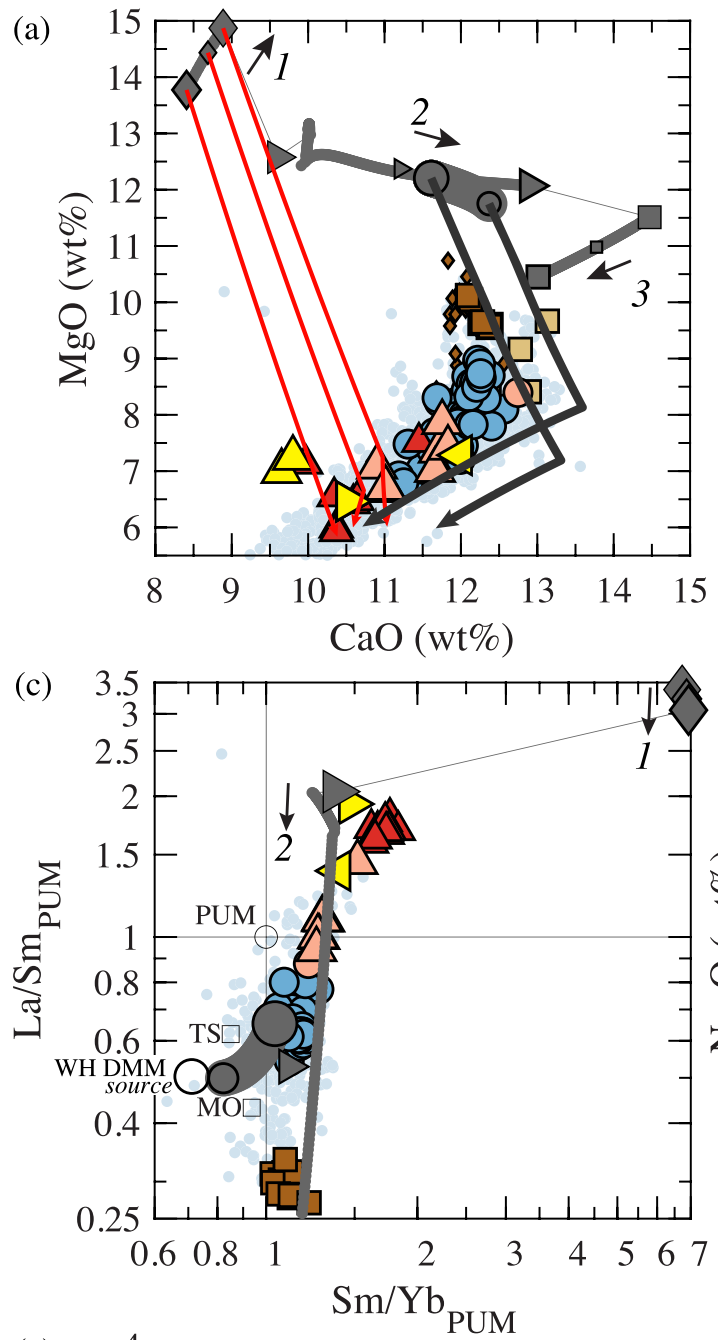

(e)

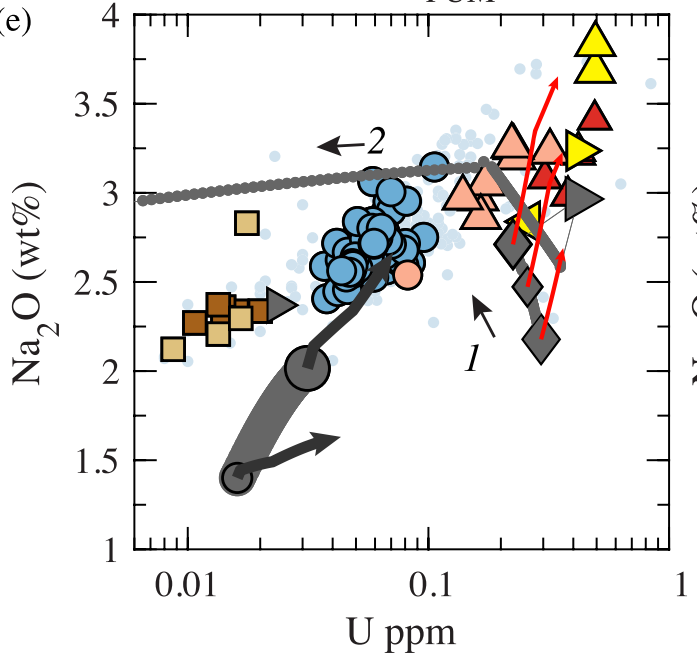

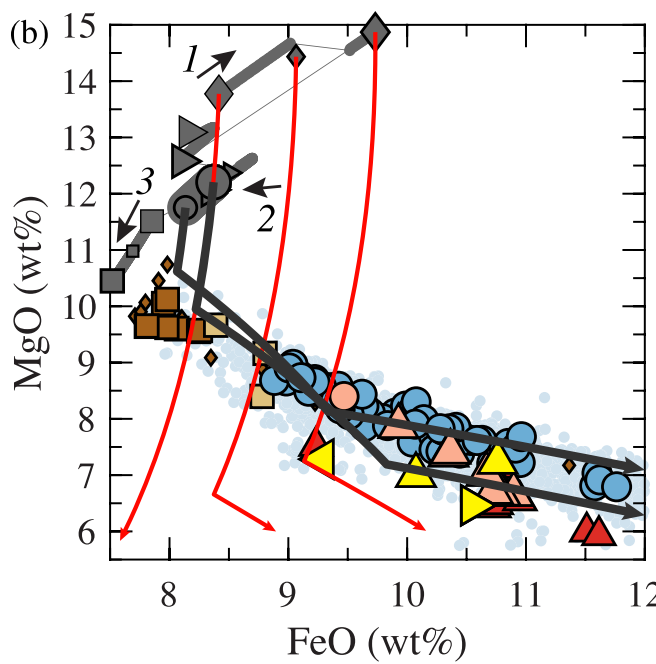

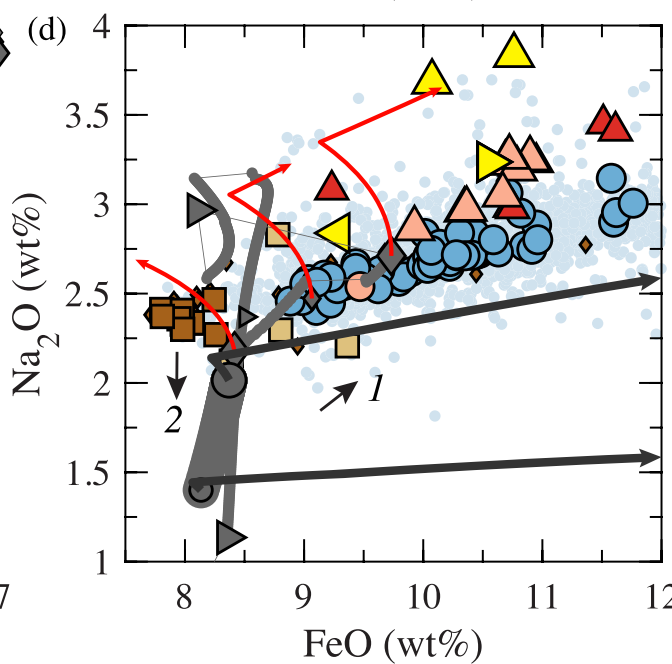

(f)

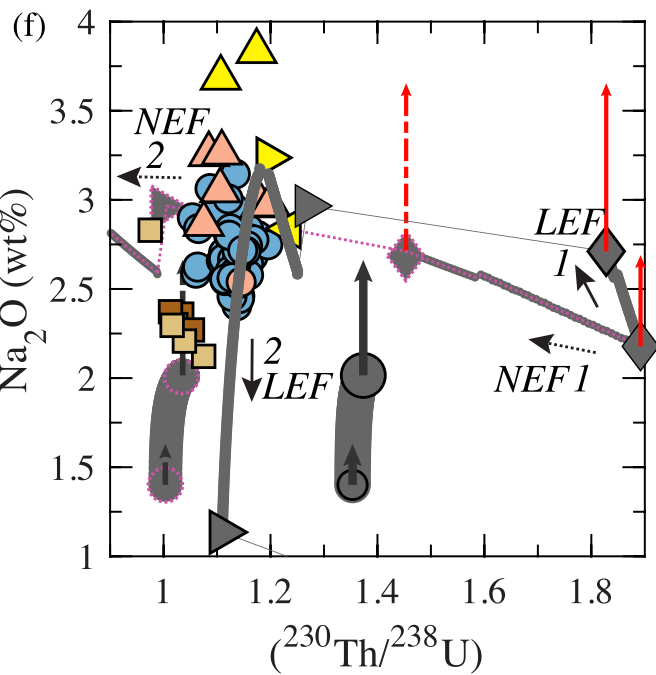

MODEL

Primary melts

Variably pooled

OFull

Near-fractional

garnet 1st avg. last

$\Delta \cdots \nu^{\circ}$

spinel 1st avg. jast

plag 1st avg. last

Schematic direction

of near-frac. melting

$1=$ garnet lherz.

$2=$ spinel lher $z$.

$3=$ plagioclase lher $\mathrm{.}$.

Fractionated melts

$\longrightarrow$ pooled

$\longrightarrow$ near-fractional

\section{Panel $F$}

symbols as above show

local-element frac. (LEF)

net-element frac. $(N E F)$ :

(1) primary melts

$\rightarrow$ near-frac. melts

$\ldots$ fractionated pooled

$\Longrightarrow$ fractionated near-frac

garnet lherz. melts

\section{EPR 8-10 ${ }^{\circ} \mathrm{DATA}$}

\section{EarthChem}

\section{Mostly D-MORB}

$\diamond$ Perfit et al.96

- $\square$ Lundstrom et al. 99

$\square$ Seamounts

Lundstrom et al. 99

$N$-MORB

Lundstrom et al. 99

Sims et al. 02

Sims et al. 03

Waters et al. 13

O E/N-MORB

Waters et al. 11

Mostly E-MORB

$\triangle$ Lundstrom et al. 99

$\triangleright$ ALV2390-1

$\triangle$ R52-4

$\triangle$ Waters et al. 11

$\triangle$ EarthChem $\mathrm{Sm} / \mathrm{Yb}_{\mathrm{PUM}}>1.5$

Figure 12. (a-f) Plots showing how well modeled garnet-peridotite melting fits the variable garnet signatures in EPR E-, N-, and D-MORBs in major element, trace element, and short-lived isotope spaces. Near-fractional garnet melts tend to be too enriched while pooled melts tend to be too depleted to match the EPR E- and N-MORBs (panels c-f). D-MORBs cannot be reproduced, particularly in panels (c) and (e). See text for more discussion. Model assumes a porosity $\phi=0.1 \%$, a Workman and Hart (2005) DMM major and trace element source, $T_{\mathrm{P}}=1400^{\circ} \mathrm{C}$, a $6 \mathrm{~cm} / \mathrm{yr}$ half spreading rate, and $350 \mathrm{ppm}$ water, which leads to garnet-lherozlite melting $\left(\zeta_{\mathrm{P}}=3.3 \%\right)$ and a crustal thickness of $6.5 \mathrm{~km}$. Primary melts are fractionally crystallized to $6 \mathrm{wt} \% \mathrm{MgO}$. Other trace element sources shown in panel (c) include TS = this study, MO = McKenzie and O'Nions (1991), and PUM. 
reproduce using Petrogen for many reasons. The erupted basalts exhibit clear trends among E-, N-, and D-MORB in major element, trace element, and isotope space. Moreover, the major element compositions of the N-MORBs are similar to average N-MORB, and the trace element compositions of the E-MORBs are similar to average E-MORB. The basalts are also well studied for U-series (including but not limited to Jull et al., 2002; Lundstrom et al., 1999; Sims et al., 2002, 2003; Volpe et al., 1993; Waters et al., 2011, 2013), and the ${ }^{230}$ Th excesses found in E-MORBs and the N-MORBs are often linked to garnet-bearing sources, yet it is spreading sufficiently fast $(\sim 5.5 \mathrm{~cm} / \mathrm{yr}$ half spreading rate) that it can be challenging to explain their magnitude (Jull et al., 2002; Spiegelman \& Elliott, 1993). In addition, long-lived isotopes indicate that the N-MORBs, D-MORBs, and at least one E-MORB (Waters et al., 2011) are derived from same long-lived isotopic source, but that most of the E-MORBs are derived from a distinct isotopic source (Sims et al., 2002).

\subsection{True Garnet Signatures Produced by Near-Fractional Melting of Garnet Lherzolite: Comparison to EPR E-MORBs}

To match E-MORBs with $\left({ }^{230} \mathrm{Th} /{ }^{238} \mathrm{U}\right)>1.2$ at the $8-10^{\circ} \mathrm{N}$ EPR and elsewhere, many models of MORB $\mathrm{U}$-series disequilibria require that very low degree near-fractional melts of garnet-bearing sources generated at the base of the melting column erupt without significantly mixing with other melts. For example, basalts ALV2390-1 and R52-4 in Lundstrom et al. (1999), Jull et al. (2002), and Elliott and Spiegelman (2014) (Figure 12, yellow triangles) are often assumed to be the garnet signature end-member melt, although Lundstrom et al. (1999) suggest that there could have been an even purer not sampled E-MORB than ALV2390-1. These minimally contaminated low-degree melts are thought to be preserved and isolated by melt extraction into channels (Spiegelman \& Kelemen, 2003). However, for this to be true, then the major and trace element compositions of these same near-fractional garnet-equilibrated melts must be distinct and reflect garnet. Using Petrogen, we find that they do not.

For example, in some major element spaces, modeled highly fractionated near-fractional garnetlherzolite melts with $\sim 6 \mathrm{wt} \% \mathrm{MgO}$ (end of red lines in Figures 12a, 12b, 12d, and 12e) can overlap some EPR E-MORBs, including ALV2390-1 and R52-4 (red, yellow, and salmon triangles). Yet none of the intermediate Mg\# melts formed along the required fractional crystallization path are observed (no EPR data overlap the red lines in Figures 12a, 12b, and 12d). These same modeled highly fractionated near-fractional garnet-lherzolite melts have larger ${ }^{230} \mathrm{Th}$ excesses and stronger garnet trace element signatures (gray diamonds, Figures 12c and 12f) than what are found in the EPR E-MORBs, even assuming a Workman and Hart (2005) DMM source. Unlike trace element ratios (Figure 12c), the large ${ }^{230}$ Th excesses of near-fractional garnet-lherzolite melts may be lowered during a lengthy melt transport time, but the extent of this decay is limited (Volpe et al., 1993; Waters et al., 2011). In addition, fast mantle and melt velocities (i.e., net-element fractionation) cannot cause near-fractional garnet melts to match the E-MORBs: Pure net-element fractionation conditions produce ${ }^{230} \mathrm{Th}$ excesses (pink dotted line between diamonds in Figure 12f) that are still higher than the EPR E-MORBs (yellow, red, and salmon triangles) - a conclusion that is consistent with two porosity models that assume net-element fractionation and channelization at the onset of melting. Combined, it is unlikely for the EPR E-MORBs to be near-fractional garnet-lherzolite melts.

\subsection{True Garnet Signatures Produced by Pooling Melts That Include Some Melts of Garnet Lherzolite: Comparison to EPR N-MORBs}

Many models of U-series disequilibria explain EPR MORBs (and global MORBs) with $\left({ }^{230} \mathrm{Th} /{ }^{238} \mathrm{U}\right)=\sim 1.1-$ 1.2 as mixtures of melts of D-MORBs and enriched E-MORB-like melts that have equilibrated with garnet peridotite or garnet pyroxenite (e.g., Jull et al., 2002; Lundstrom et al., 1999; Sims et al., 2002; Waters et al., 2011). These mixed MORBs tend to be N-MORBs (blue circles in Figure 12), although many E-MORBs have similar ${ }^{230} \mathrm{Th}$ excesses (blue, salmon, and yellow symbols all overlap along $x$ axis in Figure 12f). Because N-MORBs are potentially pooled melts, especially at an intermediate-spreading ridge such as the EPR, we compare EPR N-MORBs to Petrogen pooled melts that contain melts of garnet lherzolite (gray circles and dark lines in Figure 12). We find that pooled melts (a particular type of mixed melt) either fail or provide no benefit to explaining EPR N-MORBs.

Specifically, the major element compositions of these pooled melts fail to match EPR N-MORBs. The problem is clear in $\mathrm{Na}_{2} \mathrm{O}-\mathrm{FeO}$ space where modeled fractionated pooled melts (dark gray lines in Figure 12d) 
(a)

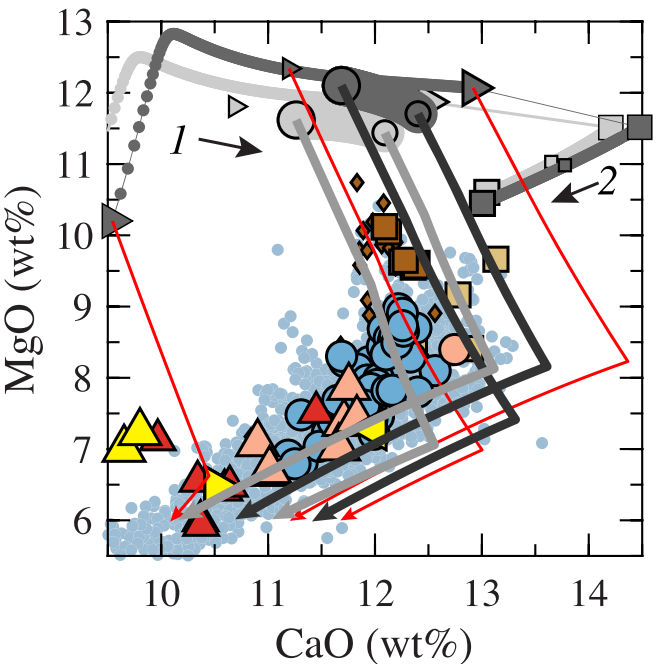

(c)

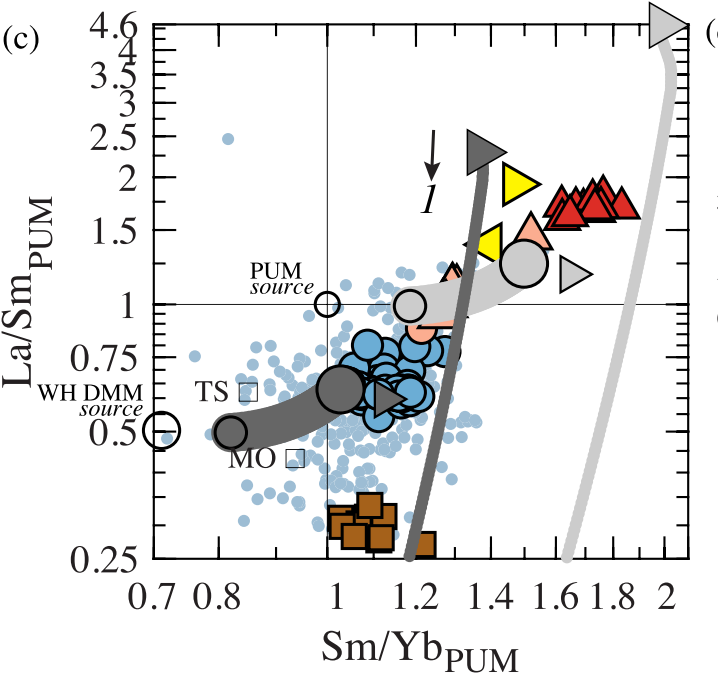

(e)

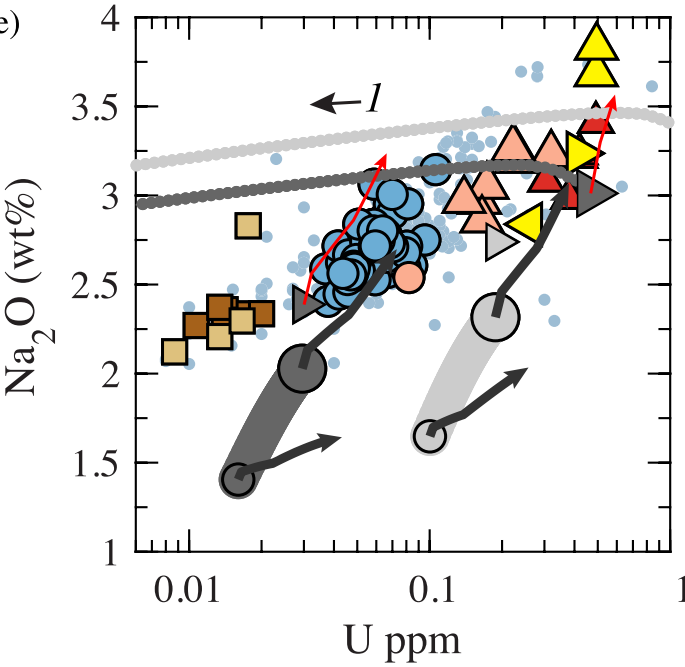

(b)

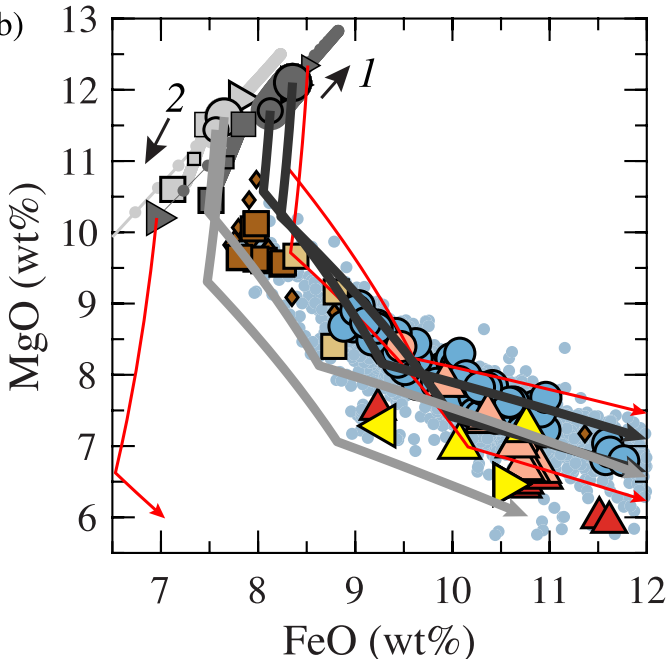

(d)
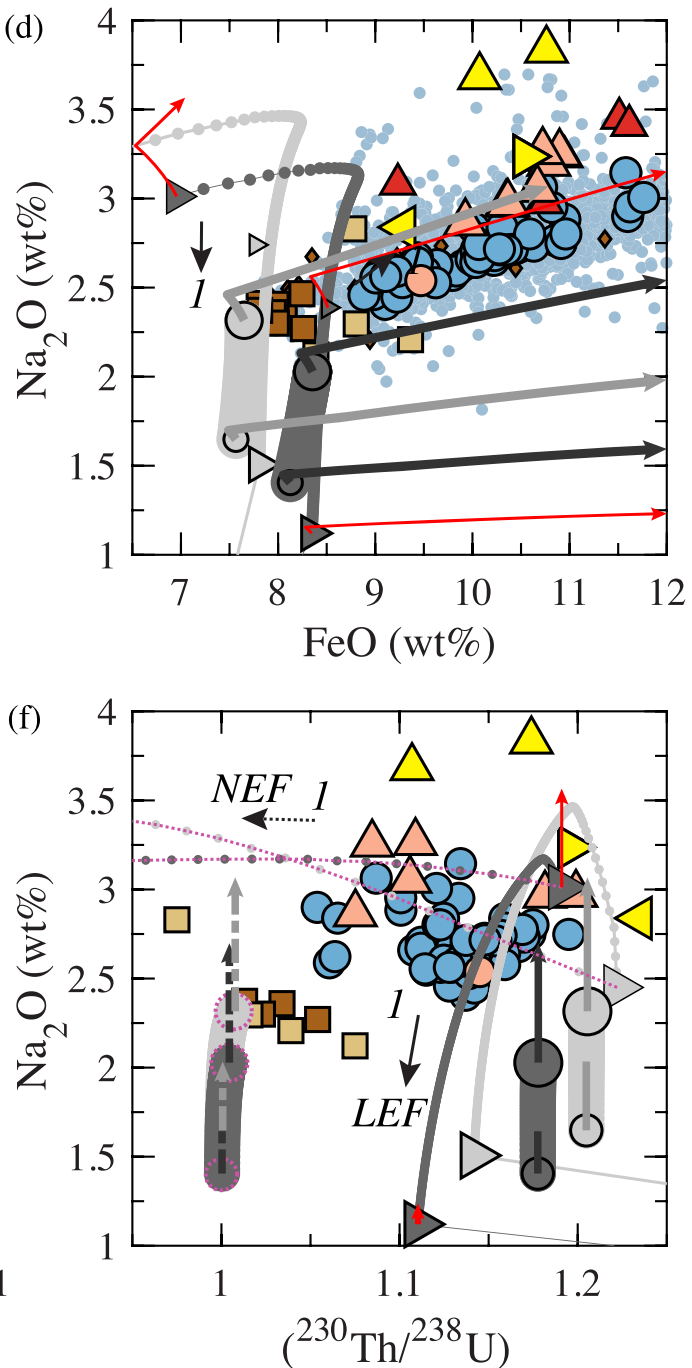

MODELS

Major \& trace source:

Dark grey: WH DMM

Light grey: PUM

Model primary melts

Variably pooled

Full

On-axis

Near-fractional spinel $1 \mathrm{st}$ avg. Jast plag 1st avg. last Schematic direction of near-frac. melting $l=$ spinel lher . $2=$ plagioclase lherz.

Fractionated melts $\longrightarrow$ pooled (DMM) $\longrightarrow$ pooled (PUM) $\longrightarrow$ near-fractional spinel-lherz. (DMM)

\section{Panel F}

symbols as above show local-element frac. (LEF)

net-element frac. $(N E F)$ :

pooled melts

neoso.. near.frac.

primary melts $\Longrightarrow \Rightarrow$ fractionated

EPR 8-10 $N$ DATA

- EarthChem

Mostly D-MORB

$\diamond$ Perfit et al. 96

$\square$ Lundstrom et al. 99

Seamounts

Lundstrom et al. 99

$N$-MORB

Lundstrom et al. 99

Sims et al. 02

Sims et al. 03

Waters et al. 13

E/N-MORB Waters et al. 11

Mostly E-MORB

$\triangle$ Lundstrom et al. 99

$\triangle$ ALV2390-1

$\triangleleft$ R52-4

$\triangle$ Waters et al. 11

$\triangle$ EarthChem $\mathrm{Sm} / \mathrm{Yb}_{\mathrm{PUM}}>1.5$

Figure 13. (a-f) Plots showing how well modeled spinel-peridotite melting fits the variable garnet signatures in EPR E-, N-, and D-MORBs in major element, trace element, and short-lived isotope spaces. Two mantle sources with different major and trace element compositions are shown, WH-DMM in dark gray and PUM in light gray. Spinel-lherzolite melting can reproduce most features of the EPR basalts, except for the D-MORBs. See text for discussion. Models assume a porosity $\phi=0.1 \%, T_{\mathrm{P}}=1400^{\circ} \mathrm{C}, 6 \mathrm{~cm} / \mathrm{yr}$ half spreading rate, and a nominally anhydrous source, which leads to zero garnet-lherzolite melting $\left(\zeta_{\mathrm{P}}=0 \%\right)$ and a crustal thickness of $6.3 \mathrm{~km}$. Primary melts are fractionally crystallized to $6 \mathrm{wt} \% \mathrm{MgO}$. 
are too low in $\mathrm{Na}_{2} \mathrm{O}$ to match EPR N-MORBS. $\mathrm{Na}_{2} \mathrm{O}$ is low in these melts because the high $T_{\mathrm{P}}$ and high water contents required for garnet-lherzolite melting lead to high degrees of melting (note that for this example we use a $T_{\mathrm{P}}=1400^{\circ} \mathrm{C}$ and water content of $350 \mathrm{ppm}$ to produce a crustal thickness of $6.5 \mathrm{~km}$ ). The modeled fractionated pooled melts are also too high in $\mathrm{CaO}$ to match N-MORBs (Figure 12a). In addition, the trace element compositions of these same melts overlap MORB but only for the fully pooled melts (large gray circles with higher $\mathrm{La} / \mathrm{Sm}$ and $\mathrm{Sm} / \mathrm{Yb}$ in Figure 12c) when using a WH-DMM source composition. In major-trace space (Figure 12e), the same modeled fractionated pooled melts are generally too low in $\mathrm{Na}_{2} \mathrm{O}$ and $\mathrm{U}$ to overlap the EPR N-MORBs. If we consider ${ }^{230} \mathrm{Th}$ excesses alone, the N-MORBs with $\left({ }^{230} \mathrm{Th} /{ }^{238} \mathrm{U}\right)=1.1-1.2$ would successfully be reproduced as long as melting dominantly occurred under local-element fractionation conditions. Local-element fractionation conditions leads to pooled melts with $\left({ }^{230} \mathrm{Th} /{ }^{238} \mathrm{U}\right)=1.35-1.4$ (gray circles in Figure 12f), in contrast to net-element fractionation conditions which lead to pooled melts with $\left({ }^{230} \mathrm{Th} /{ }^{238} \mathrm{U}\right)=1-1.05$ (light gray circles with pink outlines). Even so, the low $\mathrm{Na}_{2} \mathrm{O}$ contents of these modeled and fractionated pooled melts causes them to fail to reproduce the EPR N-MORBs (Figure 12f).

A more enriched source could help to relax these constraints imposed by $\mathrm{Na}_{2} \mathrm{O}$ and $\mathrm{U}$, but changing the source composition has other problematic consequences. For example, a PUM major and trace element source would generate a fully pooled melt with a $\mathrm{Na}_{2} \mathrm{O}$ content that overlaps the EPR N-MORBs, but the same fully pooled melt would then have a trace element garnet signature that overlapped the salmon colored E-MORBs, not the blue N-MORBs (similar to light gray PUM model in Figure 13). In addition, all the pooled melts would be too enriched in U to match the N-MORBs. A Na-rich major element source (e.g., PUM), but a less enriched trace element source (e.g., this study calculated here in section 3.3), may resolve this majortrace-isotope problem, but even so, it would be impossible to simultaneously explain the EPR D-MORBs (brown symbols in Figure 12). EPR D-MORBs have identical long-lived isotopes as the EPR N-MORBs (Lundstrom et al., 1999; Sims et al., 2002) and should be relatable by the melting process. For this to be true, D-MORBs must be either intermediate near-fractional melts of the melting column or more narrowly pooled melts that sample a higher proportion of high-degree melts. We have found, however, that in models that produce some garnet-lherzolite melting, neither option satisfactorily explains the D-MORBs: Modeled intermediate-degree near-fractional melts have too little $\mathrm{Na}_{2} \mathrm{O}$ and too much $\mathrm{U}$, and modeled narrowly pooled melts have too much $\mathrm{Na}_{2} \mathrm{O}$ and too little $\mathrm{U}$ (Figures $12 \mathrm{c}$ and 12e). Therefore, we conclude that pooled melts produced under conditions where melting starts in the garnet-lherzolite field are unlikely to be important for MORs, including at fast- and intermediate-spreading ridges such as the EPR. Our conclusion is in agreement with Hirschmann and Stolper (1996), although we suggest garnet is not critical for explaining MORB garnet signatures on the basis of composition rather than on crustal thickness.

\subsection{Apparent Garnet Signatures Produced by Melting Spinel Lherzolite: Comparison to EPR E-,} N-, and D-MORBs

Given the challenges in generating true garnet signatures in MORB by melting garnet peridotite, we now explore the conditions under which spinel peridotite melting might explain garnet signatures in $\mathrm{E}-$ and $\mathrm{N}$ MORB. This idea is not new; many models of $U$-series disequilibria and other garnet signatures invoke channelization and preservation of low-degree near-fractional melts of spinel lherzolite to explain MORB with large ${ }^{230}$ Th excesses (e.g., Chauvel \& Blichert-Toft, 2001; Landwehr et al., 2001; Turner et al., 2000; Wood et al., 1999). We, in agreement, find that the initial low-degree, $\phi=\sim 0.1 \%$, near-fractional melts of DMM spinel lherzolite are better matches to E-MORBs than near-fractional garnet melts in major element, trace element, and short-lived isotope space (dark gray triangles and dashed-dotted lines overlap the yellow, salmon, and red triangles in Figures 13c, 13e, and 13f). We note that while the very first extracted low-degree near-fractional spinel-lherzolite melts do not overlap the E-MORBs in major element space (e.g., the dark gray dash-dotted line that plots far from all EPR data in Figures 13a, 13b, and 13d), near-fractional melts extracted at slightly higher degrees of melting do explain the E-MORBs (e.g., E-MORBS plot between the ends of these other dark gray dash-dotted lines in Figures 13a, 13b, and 13d).

The problem with $\phi=0.1 \%$ spinel-lherzolite melting is not reproducing the EPR E-MORBs, but in reproducing the major and trace element compositions of the EPR N-MORBs and D-MORBs. In this case, generating the ${ }^{230}$ Th excesses in the N-MORBs and D-MORBs is not challenging; modeled melts match under conditions intermediate to local- and net-element fractionation (e.g., blue circles and brown squares plot between the modeled melts in Figure 13f). However, the same modeled fractionated variably pooled melts of DMM 
(a)

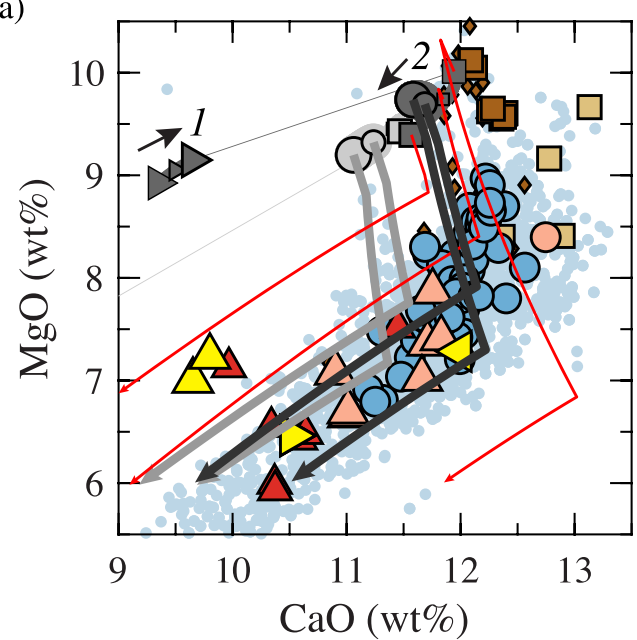

(c)

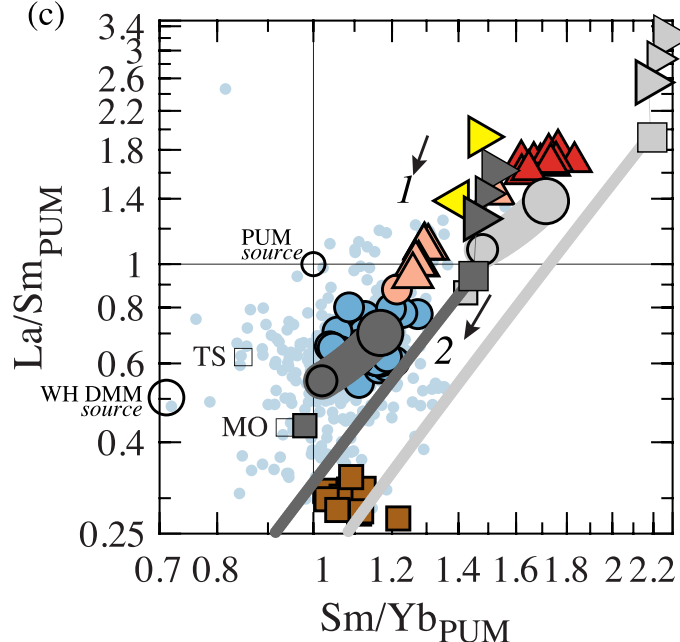

(e)

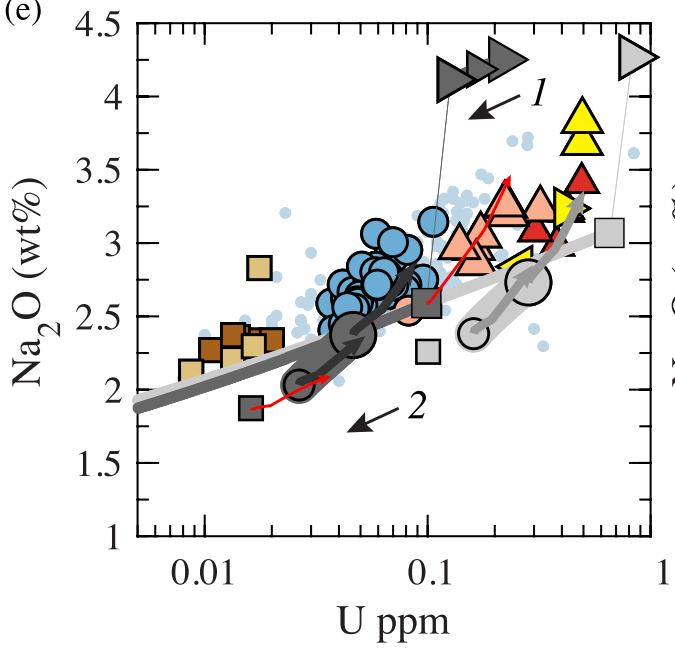

(b)

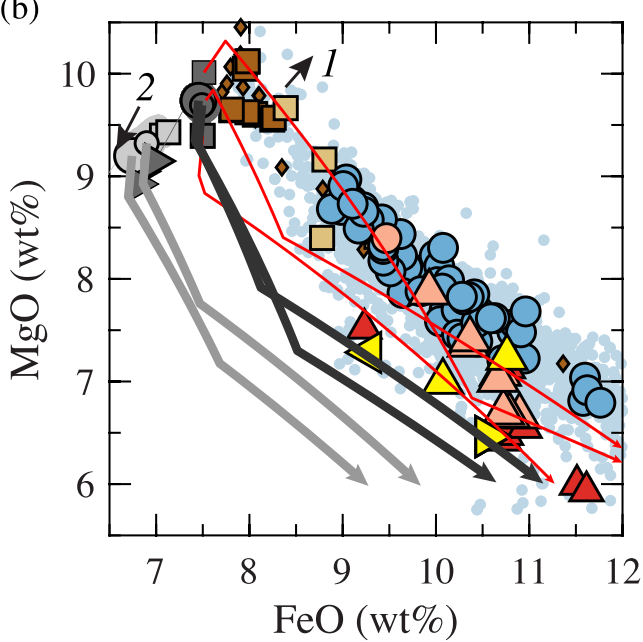

(d)

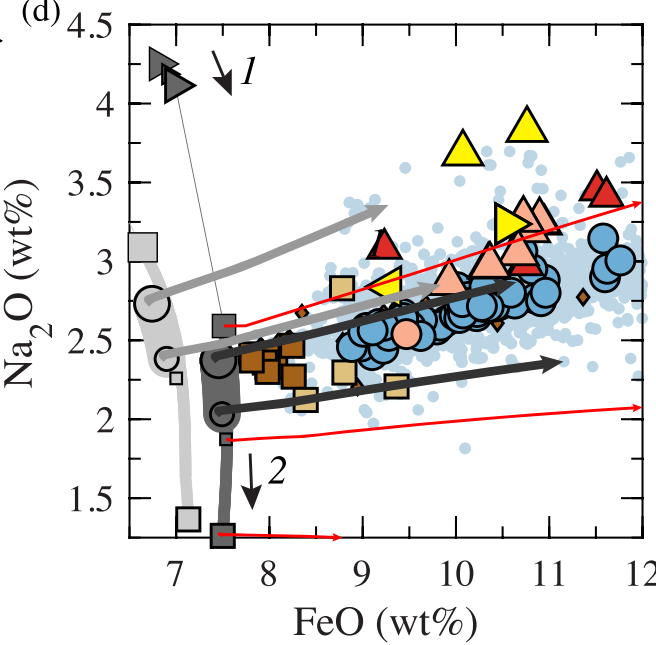

(f)

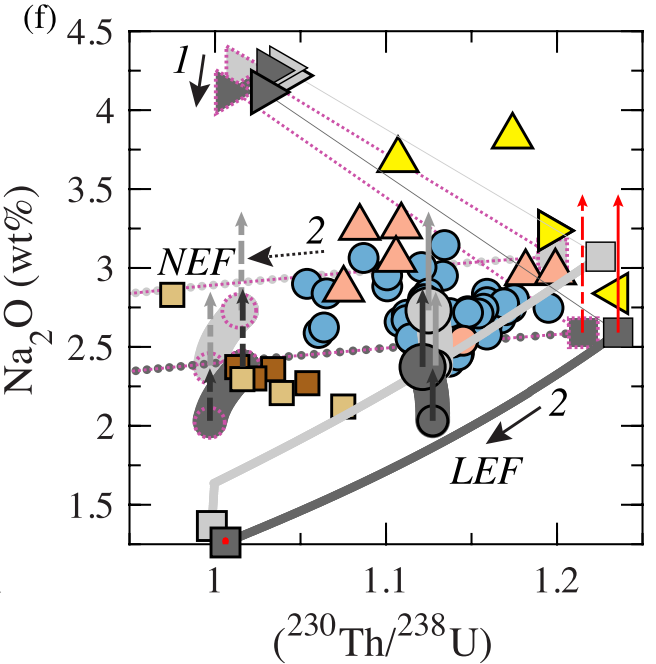

MODELS

Major \& trace source:

Dark grey: WH DMM

Light grey: PUM

Model primary melts

Variably pooled

Full

On-axis

Near-fractional spinel $1 \mathrm{st}$ avg. Jast

plag 1st avg. last

Schematic direction

of near-frac. melting

$1=$ spinel lher .

$2=$ plagioclase lherz.

Fractionated melts

$\longrightarrow$ pooled (DMM)

pooled (PUM)

near-fractional
plag-lherz. (DMM)

\section{Panel F}

symbols as above show

ocal-element frac. (LEF)

net-element frac. (NEF) melts:

pooled primary

.+os primary near-frac

$\Rightarrow \rightarrow \begin{aligned} & \text { fractionated } \\ & \text { pooled }\end{aligned}$

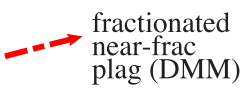

\section{EPR 8-10 $N$ DATA}

- EarthChem

2 Mostly D-MORB

$\diamond$ Perfit et al. 96

$\square$ Lundstrom et al. 99

$\square$ Seamounts

Lundstrom et al. 99

$N$-MORB

Lundstrom et al. 99

Sims et al. 02

Sims et al. 03

Waters et al. 13

E/N-MORB

Waters et al. 11

Mostly E-MORB

$\triangle$ Lundstrom et al. 99

$\triangle$ ALV2390-1

$\triangle$ R52-4

$\triangle$ Waters et al. 11

$\triangle$ EarthChem

$\mathrm{Sm} / \mathrm{Yb}_{\mathrm{PUM}}>1.5$

Figure 14. (a-f) Plots showing how well modeled $\phi=1 \%$ plagioclase-peridotite melting fits the variable garnet signatures in EPR E-, N-, and D-MORBs in major element, trace element, and short-lived isotope spaces. Two mantle sources with different major and trace element compositions are shown, WH-DMM in dark gray and PUM in light gray. Model can reproduce all EPR E-, N-, and D-MORBs. See text for discussion. Models assume a porosity $\phi=1 \%, T_{\mathrm{P}}=1300^{\circ} \mathrm{C}$, $6 \mathrm{~cm} / \mathrm{yr}$ half spreading, and a nominally anhydrous source, which leads to zero garnet-lherzolite melting $\left(\zeta_{\mathrm{P}}=0 \%\right)$ and a crustal thickness of $\sim 2.5 \mathrm{~km}$. Primary melts are fractionally crystallized to $6 \mathrm{wt} \% \mathrm{MgO}$. 
are too low in $\mathrm{Na}_{2} \mathrm{O}$ to match the N-MORBs (dark gray circles and solid lines in Figures 13d-13f). These same melts are also too low in $\mathrm{Na}_{2} \mathrm{O}$, as well as too high in $\mathrm{La} / \mathrm{Sm}, \mathrm{Sm} / \mathrm{Yb}$, and $\mathrm{U}$, to overlap the D-MORBs (brown squares, Figures $13 \mathrm{c}$ and 13e). Near-fractional melts also fail to explain the D-MORBs; near-fractional melts with concentrations of $U$ relevant to the D-MORBs would have much higher $\mathrm{Na}_{2} \mathrm{O}$ contents than in the D-MORBs (e.g., small gray circles in Figure 13e). This inability to reproduce first-order features of D-MORBs is a serious problem, especially given that they are likely part of the same melting column with the same source as the N-MORBs (Sims et al., 2002).

Some of these problems in producing N- and D-MORBs may be mitigated by the presence of multiple sources with different major and trace element compositions (such as PUM and DMM), as suggested by long-lived isotopic heterogeneity. In this case, the E-MORBs could then be pooled melts (not near-fractional melts) of an enriched source (light gray model in Figure 13). The N-and D-MORBs could then be near-fractional and pooled melts of a more depleted source (dark gray model in Figure 13). Future modeling and experimental work to constrain which if any specific major and trace element source compositions could reproduce all features of these E-, N-, and D-MORBs is needed to test the likelihood of such a multiple-source model.

\subsection{Apparent Garnet Signatures Produced by Melting Plagioclase Lherzolite: Comparison to EPR E-, N-, and D-MORBs}

Even if appropriate source conditions are found that match the EPR major element, trace element, and isotope (short- and long-lived) compositions for either melting garnet or spinel lherzolite, the solutions will always require a very low mantle porosity of $\phi=0.1 \%$. In the case of garnet lherzolite, a low $\phi$ is required to extract melts in the garnet field at mantle temperatures consistent with crustal thickness. In the case of spinel lherzolite, a low $\phi$ is required to generate ${ }^{230} \mathrm{Th}$ excesses $>\sim 1.2$ in either near-fractional or pooled melts, given what we currently know about $U$ and Th partitioning. This conclusion is consistent with all interpretations of U-series data. In contrast, experiments (Kohlstedt, 1992; Zhu et al., 2011), theory (Faul, 2001), and seismic observations (Forsyth et al., 1998) all suggest that $\phi$ is at least $1 \%$ during melting. Thus, there is enough evidence that $\phi$ must be significantly larger than $0.1 \%$ that it is important to consider alternative scenarios for explaining MORB U-series garnet signatures.

Using Petrogen, we have identified the one scenario in which garnet signatures could be produced by melting peridotite with $\phi=1 \%$ that is also consistent with E-, N-, and D- MORB major elements, trace elements, and isotopes: a significant role of residual plagioclase during melting. For plagioclase to impart any meaningful geochemical signature requires that melting start very near to the spinel-plagioclase boundary, and therefore requires low $T_{\mathrm{P}}<1350^{\circ} \mathrm{C}$ conditions. This scenario, illustrated in Figure 14 assuming $T_{\mathrm{P}}=1300^{\circ}$ $\mathrm{C}$, produces higher-degree near-fractional melts, as well as pooled melts, with enough $\mathrm{U}$ and $\mathrm{Na}_{2} \mathrm{O}$ to overlap both D-MORBs and N-MORBs (blue circles and brown squares match dark gray model in Figures 14c-14f). The MgO content of the pooled and near-fractional melts is low compared to the EPR basalts (Figures $14 \mathrm{~b}$ and $14 \mathrm{e}$ ), but this misfit can be solved by increasing the $T_{\mathrm{P}}$ from $1300^{\circ} \mathrm{C}$ to $\sim 1330^{\circ} \mathrm{C}$ and/or slightly changing the source bulk composition. The E-MORBs can also be explained by near-fractional melts or pooled melts of an enriched and isotopically distinct source (light gray model matches yellow, red, and salmon triangles in Figure 14).

Melting with plagioclase works with $\phi=1 \%$ because the Na-rich plagioclase present at the onset of melting can have $\mathrm{D}_{\text {Plag }}^{\mathrm{U}} / \mathrm{D}_{\text {Plag }}^{\text {Th }}>1$, as well as large $\mathrm{D}_{\text {Plag }}^{\mathrm{U}}$ and $\mathrm{D}_{\text {Plag }}^{\text {Th }}>0.02$ (Sun et al., 2017) (Figure 3), which leads to large ${ }^{230}$ Th excesses in both near-fractional and pooled melts (Figure 10d and Figure 14f, gray squares and circles). Larger Ds and larger $\phi$, in turn, would also allow for quick attainment of local-element-fractionation conditions at the faster-spreading rates present at the EPR (Spiegelman \& Elliott, 1993). As melting progresses, $\left({ }^{230} \mathrm{Th}\right) /\left({ }^{238} \mathrm{U}\right)$ of near-fractional melts will approach 1 by the time melting ends at $12 \%$ due to the decreasing mode of plagioclase in our model (Figure 14f, gray squares). For DMM, at the phase transition, there is $5.6 \%$ plagioclase in the residual mantle that decreases to $0.8 \%$ by the time melting stops. While we have not in this paper directly discussed ${ }^{226}$ Ra excesses, the decreasing $\mathrm{D}_{\text {Bulk }}^{\mathrm{U}} / \mathrm{D}_{\text {Bulk }}^{\text {Th }}$ due to this diminishing mode of plagioclase would easily generate the observed anticorrelated ${ }^{230}$ Th excesses and ${ }^{226}$ Ra excesses in the EPR basalts and other MORBs. In addition, Na-rich and Na-poor plagioclase will be able to produce ${ }^{226}$ Ra excesses with $\phi=1 \%$ because plagioclase is significantly more compatible in Ra than other mantle minerals ( $D_{\text {Plag }}^{\text {Ra }}>0.02-0.5$ Fabbrizio et al., 2009; Miller et al., 2007). If this low $T_{P}$ model with $\phi=1 \%$ is relevant for 
MORs, then we would need to recalculate the estimated DMM source composition as in Figure 11; a low $T_{\mathrm{P}}=1300^{\circ} \mathrm{C}$ plagioclase-lherzolite source will not require as much of a preexisting garnet signature as did the higher $T_{\mathrm{P}}$ assumed in Figure 11 (i.e., model in Figure 14c matches N-MORBs well with WH-DMM).

Overall, the strength of this $\phi=1 \%$ plagioclase-peridotitedominated melting scenario is that the pooled melts and near-fractional melts are consistent with major elements (Fujii \& Bougault, 1983; Kinzler \& Grove, 1992a), trace elements, and ${ }^{230}$ Th excesses (and ${ }^{226}$ Ra excesses) (Figure 14), as well as experimental, theoretical, and seismic constraints on $\phi$ (Faul, 2001; Forsyth et al., 1998; Kohlstedt, 1992; Zhu et al., 2011). The challenge, however, with the $\phi=1 \%$ plagioclase lherzolite model, even though it fits major and trace elements better than melts of spinel or garnet lherzolite, is matching MORB crustal thickness-the opposite problem as found by Hirschmann and Stolper (1996) for garnet lherzolite. With $\phi=1 \%$ and $T_{\mathrm{P}}=1300^{\circ} \mathrm{C}$, only a maximum $\sim 3 \mathrm{~km}$ of crust is produced (Figure 11). Increasing $T_{\mathrm{P}}$ will increase crustal thickness, but it cannot be increased so much as to cause significant melting in the spinel-stability field. Increasing water content can help, but not enough to produce an extra $3 \mathrm{~km}$ of crust. There are, however, at least two solutions for this problem. One is that the mantle could be refertilized by deeper, Na-rich melts at the depths at which plagioclase stabilizes (P. B. Kelemen, personal communication, December 2019), which would allow for melts enriched in sodium to be produced that overlap MORB at higher mantle potential temperatures. Normally, when $T_{\mathrm{P}}=1400^{\circ} \mathrm{C}$, near-fractional plagioclase-field melts are extremely depleted in $\mathrm{Na}_{2} \mathrm{O}(<1 \mathrm{wt} \%)$ and plot outside of the axes in Figures 12 and 13. Refertilization is often discussed in the hot mantle lithosphere or in the shallowest asthenosphere and can be conceived of in the framework of melt-rock reaction (Dygert et al., 2016; Müntener et al., 2004, 2010). In addition, melt interaction with plagioclase in the crust has been suggested to be important for explaining many aspects of U-series disequlibria in basalts (Saal \& Van Orman, 2004; Saal et al., 2007; Van Orman \& Saal, 2009; Van Orman et al., 2006). The other, perhaps related, solution is modeling a pressure-dependent melt productivity $(\mathrm{d} F / \mathrm{d} P)$ that increases with $F$. An $F$-sensitive melt productivity could significantly suppress melting in the spinel-stability field such that-even with higher $T_{\mathrm{P}}$ and deeper melting — melting becomes much more productive after crossing the spinel-plagioclase boundary. In this case, the bulk of the $6 \mathrm{~km}$ of oceanic crust would be generated at pressures more shallow than the plagioclase-spinel boundary.

Both of these solutions that would increase crustal production for the $\phi=1 \%$ plagioclase lherzolite model suggest that something interesting could be occurring at the spinel-plagioclase boundary. Given that the energy required for the spinel-plagioclase phase transition acts as a speed bump and barrier to melting (Asimow et al., 1995), the transition itself may regulate melting, mixing, and refertilization and allow for ingrowth of ${ }^{230} \mathrm{Th}$. Moreover, even without directly considering the phase transition, geodynamical models with stress-dependent rheology, such as the one used here, predict that upwelling velocities (and therefore, crustal production) increase near the surface, supporting the idea that shallow melting (and reaction) is critical for understanding the compositions of MORBs.

\section{Garnet Signatures by Melting Nonperidotite or Randomly Mixing Melts With Variable Garnet Signatures}

In this paper we have focused on reproducing the range of compositional variability in E-, N-, and D-MORBs with variable garnet signatures by melting peridotite alone. We have shown that the full range of MORB variability is reproduced by melting compositionally (major and trace element) and thermally variable peridotite and the eruption of both near-fractional melts and variably pooled melts. We cannot, however, rule out other ways to explain garnet signatures. The other proposed processes include melting garnet pyroxenite and the often related process of randomly mixing melts with variable garnet signatures. For mixing, the end-member with the garnet signature could be a melt of a garnet-bearing source (garnet peridotite, Jull et al., 2002; or garnet pyroxenite, Elkins et al., 2014, 2016; Hirschmann \& Stolper, 1996; Koornneef et al., 2012; Lundstrom et al., 1999; Scott et al., 2018; Waters et al., 2011) or a low-degree melt of spinel (or perhaps plagioclase) peridotite.

For models that invoke random mixing, mixing proportions differ between models depending on assumptions about the end-members. Some models use erupted MORBs as an end-member (e.g., Jull et al., 2002; Lundstrom et al., 1999), while others do not (e.g., Waters et al., 2011). Even so, Waters et al. (2011) found that EPR E-MORBs only require mixing of a small amount (5\%) of a $1 \%$ melt of a garnet pyroxenite, 
similar to the maximum 5-10\% estimated by Lundstrom et al. (1999). Hirschmann and Stolper (1996), by contrast, find that significantly less enriched global N-MORBs require mixing in a much larger amount $(\sim 20 \%)$ of a garnet-pyroxenite melt. In general, models that predict smaller proportions of garnet-bearing sources tend to assume higher $\mathrm{D}_{\text {Bulk }}^{\mathrm{U}} / \mathrm{D}_{\text {Bulk }}^{\text {Th }}$, a larger garnet mode (i.e., usually pyroxenite or eclogite), and/or lower $\phi$. These choices lead to melts with large $\left({ }^{230} \mathrm{Th}\right) /\left({ }^{238} \mathrm{U}\right)>2$ that must be diluted to match the lower maximum $\left({ }^{230} \mathrm{Th}\right) /\left({ }^{238} \mathrm{U}\right)=\sim 1.25-1.5$ in MORBs. It is important to note that because $\mathrm{D}_{\text {Bulk }}^{\mathrm{U}}$ and $\mathrm{D}_{\text {Bulk }}^{\text {Th }}$ strongly depend on the composition of the garnet-bearing source and the temperature/pressure of melting (Elkins et al., 2008; Salters \& Longhi, 1999; van Westrenen et al., 2001), these different models actually require very specific and different garnet-bearing sources. What exactly these source lithologies are is often unclear. Furthermore, for random mixing to be a viable process to explain MORBs, mixing proportions for any individual MORB must be consistent in all major element, trace element, and isotope spaces. It is also not often clear if a proposed mixing model passes this criteria even for a few trace elements in a single basalt.

In addition to the complexity posed by consistent mixing proportions between end-members, garnetpyroxenite melts (a potential end-member) are highly variable in composition. Some garnet-pyroxenite melts overlap MORB, some are similar to peridotite melts, and some are distinct from both (Lambart et al., 2012). Rigorously testing for the role of garnet pyroxenite in MORB will thus require major and trace element modeling (and experiments) of garnet pyroxenite melting and mixing under different temperature and pressure conditions, with different masses of heterogeneities, to determine if the major element, trace element, and isotope composition of melts of garnet pyroxenite can match MORBs with garnet signatures. These variables are very important. For example, if veins or blocks of mafic garnet pyroxenites have melting temperatures similar to peridotite (Lambart et al., 2016), then the melts of these pyroxenites are likely to reequilibrate by diffuse porous flow rather than be extracted in their pure form (Katz \& Weatherley, 2012). Depending on the relative masses of the heterogeneities involved and the mantle temperature and pressure, reequlibrated melts and residues might exhaust garnet and stabilize a more enriched lherzolite or a pyroxene-rich residue (Lambart et al., 2009, 2012; Liu \& Liang, 2017; Mitchell \& Grove, 2015).

\section{Conclusion}

New modeling suggests that extraction of garnet-lherzolite melts only occurs under high $T_{\mathrm{P}}$, high water contents, and low mantle porosity $(\phi)$ conditions. The major element compositions of low-degree garnetlherzolite melts are highly distinctive with low $\mathrm{CaO}$ and high $\mathrm{MgO}$ and $\mathrm{FeO}$ contents. When these melts are fractionally crystallized, their major element compositions are a very poor fit to MORB. Similarly, near-fractional garnet-lherzolite melts have trace element garnet signatures (e.g., $\mathrm{Sm} / \mathrm{Yb}$ ) that are distinctive and, in most cases, do not fit MORB, even when we take into account variable trace element source compositions. The ${ }^{230}$ Th excess compositions of near-fractional garnet-lherzolite melts are also poor fits to MORBs. Therefore, if garnet-lherzolite melting occurs at MORs, the melts must be significantly diluted in erupted melts. However, pooled melts that contain melts of garnet lherzolite have major and trace element compositions with weak to negative garnet signatures except for their large ${ }^{230} \mathrm{Th}$ excesses if melting occurs dominantly by local-element fractionation $\left({ }^{230} \mathrm{Th}\right.$ ingrowth and/or porous flow).

We find that spinel- and plagioclase-lherzolite pooled and near-fractional melts of compositionally and thermally variable mantle peridotite better produce the highly variable major element, trace element, and isotope garnet signatures in E-MORB, N-MORB, and D-MORB, as well as MORB crustal thickness. Our finding is consistent with two-porosity models and fully reactive melt transport models (Elliott \& Spiegelman, 2014, and references therein). Even so, we find that spinel-peridotite melting, which requires low mantle porosity $\phi=0.1 \%$ to produce ${ }^{230}$ Th excesses, cannot simultaneously explain D-MORBs as melts of the same source as N-MORBs even though they have identical long-lived isotopic compositions. We have identified a new model that reconciles the D-MORB problem by melting plagioclase peridotite with $\phi=1 \%$ and also simultaneously satisfies E-MORB, N-MORB, and D-MORB major element, trace element, and isotopic $\left({ }^{230}\right.$ Th excesses, ${ }^{226}$ Ra excesses, and long-lived) constraints. Because this $\phi=1 \%$ model relies on a significant role of Na-rich plagioclase, it requires either shallow mantle refertilization or melt initiation near the spinel-plagioclase boundary (such as when $T_{\mathrm{P}}=\sim 1300-1350^{\circ} \mathrm{C}$ ) and concomitant significant crustal production at depths shallower than the phase transition. 


\section{Data Availability Statement}

The software for this research (Petrogen) is available in the following Harvard Dataverse data citation reference: Krein et al. (2020), [MIT license], https://doi.org/10.7910/DVN/CXIT95

\section{Acknowledgments}

The authors gratefully acknowledge the thoughtful comments of the reviewers Lynne Elkins, Sarah Lambart, and John Lassiter, whose comments greatly improved this paper. The authors also gratefully acknowledge constructive suggestions and comments from Susana Hoyos and Patrick Beaudry on earlier versions of the manuscript and from Fiona Clerc for feedback on the Petrogen software. Support for this work was provided through the National Science Foundation from grants OCE-1458201 (to M. D. B), OCE-1457916 (to T. L. G), and EAR-1551321.

\section{References}

Aharonov, E., Whitehead, J. A., Kelemen, P. B., \& Spiegelman, M. (1995). Channeling instability of upwelling melt in the mantle. Journal of Geophysical Research, 100(B10), 433-20.

Asimow, P. D., Hirschmann, M. M., \& Stolper, E. M. (1997). An analysis of variations in isentropic melt productivity. Philosophical Transactions of the Royal Society A: Mathematical, Physical and Engineering Sciences, 355(1723), 255-281. https://doi.org/10.1098/ rsta.1997.0009

Asimow, P. D., \& Langmuir, C. H. (2003). The importance of water to oceanic mantle melting regimes. Nature, 421(6925), 815-820. https:// doi.org/10.1038/nature01429

Asimow, P. D., Hirschmann, M. M., Ghiorso, M. S., O'Hara, M. J., \& Stolper, E. M. (1995). The effect of pressure-induced solid-solid phase transitions on decompression melting of the mantle. Geochimica et Cosmochimica Acta, 59(21), 4489-4506. https://doi.org/10.1016/ 0016-7037(95)00252-U

Baker, M. B., \& Stolper, E. M. (1994). Determining the composition of high-pressure mantle melts using diamond aggregates. Geochimica et Cosmochimica Acta, 58(13), 2811-2827. https://doi.org/10.1016/0016-7037(94)90116-3

Balta, J. B., Asimow, P. D., \& Mosenfelder, J. L. (2011). Hydrous, low-carbon melting of garnet peridotite. Journal of Petrology, 52(11), 2079-2105. https://doi.org/10.1093/petrology/egr040

Beattie, P. (1993a). The generation of uranium series disequilibria by partial melting of spinel peridotite: Constraints from partitioning studies. Earth and Planetary Science Letters, 117(3-4), 379-391. https://doi.org/10.1016/0012-821X(93)90091-M

Beattie, P. (1993b). Uranium thorium disequilibria and partitioning on melting of garnet peridotite. Nature, 363(6424), 63-65. https://doi. org/10.1038/363063a0

Becker, M., \& Le Roex, A. P. (2006). Geochemistry of South African on- and off-craton, Group I and Group II kimberlites: Petrogenesis and source region evolution. Journal of Petrology, 47(4), 673-703. https://doi.org/10.1093/petrology/egi089

Behn, M. D., \& Grove, T. L. (2015). Melting systematics in mid-ocean ridge basalts: Application of a plagioclase-spinel melting model to global variations in major element chemistry and crustal thickness. Journal of Geophysical Research: Solid Earth, 120, $4863-4886$. https://doi.org/10.1002/2015JB011885

Bonatti, E., Ottonello, G., \& Hamlyn, P. R. (1986). Peridotites from the Island of Zabargad (St. John), Red Sea: Petrology and geochemistry. Journal of Geophysical Research, 91(B1), 599. https://doi.org/10.1029/JB091iB01p00599

Carswell, D. A. (1968). Possible primary upper mantle peridotite in Norwegian basal gneiss. Lithos, 1(4), 322-355. https://doi.org/10.1016/ S0024-4937(68)80014-3

Carter, J. L. (1970). Mineralogy and chemistry of the Earth's upper mantle based on the partial fusion-partial crystallization model. GSA Bulletin, 81(7), 2021-2034. https://doi.org/10.1130/0016-7606(1970)81[2021:MACOTE]2.0.CO;2

Chauvel, C., \& Blichert-Toft, J. (2001). A hafnium isotope and trace element perspective on melting of the depleted mantle. Earth and Planetary Science Letters, 190(3-4), 137-151. https://doi.org/10.1016/S0012-821X(01)00379-X

Davis, F. A., Tangeman, J. A., Tenner, T. J., \& Hirschmann, M. M. (2009). The composition of KLB-1 peridotite. American Mineralogist, 94(1), 176-180. https://doi.org/10.2138/am.2009.2984

Dick, H. J. B., Fisher, R. L., \& Bryan, W. B. (1984). Mineralogic variability of the uppermost mantle along mid-ocean ridges. Earth and Planetary Science Letters, 69(1), 88-106. https://doi.org/10.1016/0012-821X(84)90076-1

Donnelly, K. E., Goldstein, S. L., Langmuir, C. H., \& Spiegelman, M. (2004). Origin of enriched ocean ridge basalts and implications for mantle dynamics. Earth and Planetary Science Letters, 226(3-4), 347-366. https://doi.org/10.1016/j.epsl.2004.07.019

Dygert, N., Liang, Y., \& Kelemen, P. B. (2016). Formation of plagioclase lherzolite and associated dunite-harzburgite-lherzolite sequences by multiple episodes of melt percolation and melt-rock reaction: An example from the trinity ophiolite, California, USA. Journal of Petrology, 57(4), 815-838. https://doi.org/10.1093/petrology/egw018

Elkins, L., Gaetani, G., \& Sims, K. (2008). Partitioning of U and Th during garnet pyroxenite partial melting: Constraints on the source of alkaline ocean island basalts. Earth and Planetary Science Letters, 265(1-2), 270-286. https://doi.org/10.1016/j.epsl.2007.10.034

Elkins, L., Scott, S. R., Sims, K. W. W., Rivers, E. R., Devey, C. W., Reagan, M. K., et al. (2016). Exploring the role of mantle eclogite at mid-ocean ridges and hotspots: U-series constraints on Jan Mayen Island and the Kolbeinsey Ridge. Chemical Geology, 444, $128-140$. https://doi.org/10.1016/j.chemgeo.2016.09.035

Elkins, L. J., Sims, K. W. W., Prytulak, J., Blichert-Toft, J., Elliott, T., Blusztajn, J., et al. (2014). Melt generation beneath Arctic Ridges: Implications from U decay series disequilibria in the Mohns, Knipovich, and Gakkel Ridges. Geochimica et Cosmochimica Acta, 127, 140-170. https://doi.org/10.1016/j.gca.2013.11.031

Elliott, T. (1997). Fractionation of $\{\mathrm{U}\}$ and $\{$ Th\} during mantle melting: a reprise. Chemical Geology, 139(1-4), 165-183. https://doi.org/ 10.1016/S0009-2541(97)00034-X

Elliott, T., \& Spiegelman, M. (2014). Melt migration in oceanic crustal production: A U-series perspective, Treatise on geochemistry (Vol. 4, pp. 543-581). Elsevier. https://doi.org/10.1016/B978-0-08-095975-7.00317-X

Fabbrizio, A., Schmidt, M. W., Günther, D., \& Eikenberg, J. (2009). Experimental determination of Ra mineral/melt partitioning for feldspars and Ra-disequilibrium crystallization ages of plagioclase and alkali-feldspar. Earth and Planetary Science Letters, 280(1-4), 137-148. https://doi.org/10.1016/j.epsl.2009.01.022

Faul, U. H. (2001). Melt retention and segregation beneath mid-ocean ridges. Nature, 410(6831), 920-923. https://doi.org/10.1038/35073556 Forsyth, D. W. (1993). Crustal thickness and the average depth and degree of melting in fractional melting models of passive flow beneath midocean ridges. Journal of Geophysical Research, 98(B9), 16,073-16,079. https://doi.org/10.1029/93JB01722

Forsyth, D. W., Scheirer, D. S., Webb, S. C., Dorman, L. M., Orcutt, J. A., Harding, A. J., et al. (1998). Imaging the deep seismic structure beneath a mid-ocean ridge: The MELT experiment: The MELT seismic team. Science, 280(5367), 1215-1218. https://doi.org/10.1126/ science.280.5367.1215

Fujii, T., \& Bougault, H. (1983). Melting relations of a magnesian abyssal tholeiite and the origin of MORBs. Earth and Planetary Science Letters, 62(2), 283-295. https://doi.org/10.1016/0012-821X(83)90091-2 
Gale, A., Dalton, C. A., Langmuir, C. H., Su, Y., \& Schilling, J. G. (2013). The mean composition of ocean ridge basalts. Geochemistry, Geophysics, Geosystems, 14, 489-518. https://doi.org/10.1029/2012GC004334

Green, D. H. (1979). Petrogenesis of mid ocean ridge basalts. In The Earth, its origin, structure, and evolution (pp. 200-299).

Grove, T. L., Holbig, E. S., Barr, J. A., Till, C. B., \& Krawczynski, M. J. (2013). Melts of garnet lherzolite: Experiments, models and comparison to melts of pyroxenite and carbonated lherzolite. Contributions to Mineralogy and Petrology, 166(3), 887-910. https://doi.org/ 10.1007/s00410-013-0899-9

Harris, P. G., Reay, A., \& White, I. G. (1967). Chemical composition of the upper mantle. Journal of Geophysical Research, 72(24), 6359-6369. https://doi.org/10.1029/JZ072i024p06359

Hart, S. R., \& Zindler, A. (1986). In search of a bulk-Earth composition. Chemical Geology, 57, 247-267.

Hebert, L. B., \& Montési, L. G. (2010). Generation of permeability barriers during melt extraction at mid-ocean ridges. Geochemistry, Geophysics, Geosystems, 11, Q12008. https://doi.org/10.1029/2010GC003270

Hellebrand, E., Snow, J. E., Hoppe, P., \& Hofmann, W. (2002). Garnet-field melting and late-stage refertilization in 'residual' abyssal peridotites from the Central Indian Ridge. Journal of Petrology, 43(12), 2305-2338. https://doi.org/10.1093/petrology/43.12.2305

Herzberg, C., \& Asimow, P. D. (2015). PRIMELT3 MEGA.XLSM software for primary magma calculation: Peridotite primary magma MgO contents from the liquidus to the solidus. Geochemistry, Geophysics, Geosystems, 16, 563-578. https://doi.org/10.1002/2014GC005631. Received

Hirschmann, M. M., \& Stolper, E. M. (1996). A possible role for garnet pyroxenite in the origin of the "garnet signature" in MORB. Contributions to Mineralogy and Petrology, 124(2), 185-208. https://doi.org/10.1007/s004100050184

Jagoutz, E., Palme, H., Baddenhausen, H., Blum, K., Cendales, M., Dreibus, G., et al. (1979). The abundances of major, minor and trace elements in the Earth's mantle as derived from primitive ultramafic nodules. Proceedings Lunar and Planet Science Conference, 2 , 2013-2050.

Jull, M., Kelemen, P. B., \& Sims, K. (2002). Consequences of diffuse and channelled porous melt migration on uranium series disequilibria. Geochimica et Cosmochimica Acta, 66(23), 4133-4148. https://doi.org/10.1016/S0016-7037(02)00984-5

Katz, R. F., \& Weatherley, S. M. (2012). Consequences of mantle heterogeneity for melt extraction at mid-ocean ridges. Earth and Planetary Science Letters, 335-336, 226-237. https://doi.org/10.1016/j.epsl.2012.04.042

Kelemen, P. B., Shimizu, N., \& Salters, V. J. M. (1995). Extraction of mid-ocean-ridge basalt from the upwelling mantle by focused flow of melt in dunite channels. Nature, 375(6534), 747-753. https://doi.org/10.1038/375747a0

Kelemen, P. B., Yogodzinski, G. M., \& Scholl, D. W. (2003). Along-strike variation in the Aleutian Island Arc: Genesis of high Mg\# andesite and implications for continental crust. In J. Eiler (Ed.), Inside the subduction factory, Geophysical Monograph Series (Vol. 138, pp. 223-276). Washington, DC: American Geophysical Union. https://doi.org/10.1029/138GM11

Kinzler, R. J. (1997). Melting of mantle peridotite at pressures approaching the spinel to garnet transition: Application to mid-ocean ridge basalt petrogenesis. Journal of Geophysical Research, 102(B1), 853. https://doi.org/10.1029/96JB00988

Kinzler, R. J., \& Grove, T. L. (1992a). Primary magmas of mid-ocean ridge basalts 2. Applications. Journal of Geophysical Research, 97(B5), 6907. https://doi.org/10.1029/91JB02841

Kinzler, R. J., \& Grove, T. L. (1992b). Primary magmas of mid-ocean ridge basalts 1. Experiments and methods. Journal of Geophysical Research, 97(B5), 6885-6906.

Klein, E. M., \& Langmuir, C. H. (1987). Global correlations of ocean ridge basalt chemistry with axial depth and crustal thickness. Journal of Geophysical Research, 92(B8), 8089. https://doi.org/10.1029/JB092iB08p08089

Klein, E. M., \& Langmuir, C. H. (1989). Local versus global variations in ocean ridge basalt composition: A reply. Journal of Geophysical Research, 94(B4), 4241. https://doi.org/10.1029/JB094iB04p04241

Kohlstedt, D. L. (1992). Structure, rheology and permeability of partially molten rocks at low melt fractions. Geophysical Monograph Series, 71, 103-121. https://doi.org/10.1029/GM071p0103

Koornneef, J. M., Stracke, A., Bourdon, B., \& Meier, M. A. (2012). Melting of a two-component source beneath Iceland. Journal of Petrology, 53(1), 127-157. https://doi.org/10.1093/petrology/egr059

Krein, S., Behn, M. D., \& Grove, T. L. (2020). Petrogen. Harvard Dataverse. https://doi.org/10.7910/DVN/CXIT95

Kushiro, I. (1996). Earth processes: Reading the isotopic code. Geophysical Monograph Series, 95, 109-122. https://doi.org/10.1029/GM095 Lambart, S., Baker, M. B., \& Stolper, E. M. (2016). The role of pyroxenite in basalt genesis: Melt-PX, a melting parameterization for mantle pyroxenites between 0.9 and 5 GPa. Journal of Geophysical Research Solid: Earth, 121, 5708-5735. https://doi.org/10.1002/2015JB012762

Lambart, S., Laporte, D., Provost, A., \& Schiano, P. (2012). Fate of pyroxenite-derived melts in the peridotitic mantle: Thermodynamic and experimental constraints. Journal of Petrology, 53(3), 451-476. https://doi.org/10.1093/petrology/egr068

Lambart, S., Laporte, D., \& Schiano, P. (2009). An experimental study of pyroxenite partial melts at 1 and $1.5 \mathrm{GPa}$ Implications for the major-element composition of mid-ocean ridge basalts. Earth and Planetary Science Letters, 288(1-2), 335-347. https://doi.org/10.1016/j. epsl.2009.09.038

Landwehr, D., Blundy, J., Chamorro-Perez, E. M., Hill, E., \& Wood, B. (2001). U-series disequilibria generated by partial melting of spinel lherzolite. Earth and Planetary Science Letters, 188(3-4), 329-348. https://doi.org/10.1016/S0012-821X(01)00328-4

Liu, B., \& Liang, Y. (2017). The prevalence of kilometer-scale heterogeneity in the source region of MORB upper mantle. Science of Advanced, 3(11), 1-8. https://doi.org/10.1126/sciadv.1701872

Lundstrom, C. C. (2003). Uranium-series disequilibria in mid-ocean ridge basalts: Observations and models of basalt genesis. Reviews in Mineralogy and Geochemistry, 52(1), 175-214. https://doi.org/10.2113/0520175

Lundstrom, C. C., Sampson, D. E., Perfit, M. R., Gill, J., \& Williams, Q. (1999). Insights into mid-ocean ridge basalt petrogenesis: U-series disequilibria from the Siqueiros Transform, Lamont Seamounts, and East Pacific Rise. Journal of Geophysical Research, 104(B6), 13,035-13,048. https://doi.org/10.1029/1999JB900081

Lyubetskaya, T., \& Korenaga, J. (2007). Chemical composition of Earth's primitive mantle and its variance: 1. Method and results. Journal of Geophysical Research, 112, B03211. https://doi.org/10.1029/2005JB004223

Müntener, O., Pettke, T., Desmurs, L., Meier, M., \& Schaltegger, U. (2004). Refertilization of mantle peridotite in embryonic ocean basins: trace element and $\mathrm{Nd}$ isotopic evidence and implications for crust mantle relationships. Earth and Planetary Science Letters, 221(1-4), 293-308. https://doi.org/10.1016/S0012-821X(04)00073-1

Mandler, B. E. (2016). Experimental studies of magmatic differentiation and the effects of water on phase stability (PhD Thesis). Retrieved from (http://hdl.handle.net/1721.1/104588). Massachusetts Institute of Technology.

Mandler, B. E., \& Grove, T. L. (2016). Controls on the stability and composition of amphibole in the Earth's mantle. Contributions to Mineralogy and Petrology, 171(8-9), 1-20. https://doi.org/10.1007/s00410-016-1281-5

McDonough, W. F., \& Sun, S.-s. (1995). The composition of the Earth. Chemical Geology, 120, 223-253. 
McKenzie, D. (1985). 230Th238U disequilibrium and the melting processes beneath ridge axes. Earth and Planetary Science Letters, 72(2-3), 149-157. https://doi.org/10.1016/0012-821X(85)90001-9

McKenzie, D., \& O'Nions, R. K. (1991). Partial melt distributions from inversion of rare earth element concentrations. Journal of Petrology, 32(5), 1021-1091. https://doi.org/10.1093/petrology/32.5.1021

Miller, S. A., Burnett, D. S., Asimow, P. D., Phinney, D. L., \& Hutcheon, I. D. (2007). Experimental study of radium partitioning between anorthite and melt at $1 \mathrm{~atm}$. American Mineralogist, 92(8-9), 1535-1538. https://doi.org/10.2138/am.2007.2640

Mitchell, A. L., \& Grove, T. L. (2015). Melting the hydrous, subarc mantle: The origin of primitive andesites. Contributions to Mineralogy and Petrology, 170(2), 13. https://doi.org/10.1007/s00410-015-1161-4

Montési, L. G. J., \& Behn, M. D. (2007). Mantle flow and melting underneath oblique and ultraslow mid-ocean ridges. Geophysical Research Letters, 34, L24307. https://doi.org/10.1029/2007GL031067

Montési, L. G. J., Behn, M. D., Hebert, L. B., Lin, J., \& Barry, J. L. (2011). Controls on melt migration and extraction at the ultraslow Southwest Indian Ridge 10-16². Journal of Geophysical Research, 116, B10102. https://doi.org/10.1029/2011JB008259

Muntener, O., Manatschal, G., Desmurs, L., \& Pettke, T. (2010). Plagioclase peridotites in ocean-continent transitions: Refertilized mantle domains generated by melt stagnation in the shallow mantle lithosphere. Journal of Petrology, 51(1-2), 255-294. https://doi.org/10.1093/ petrology/egp087

O'Hara, M. J., Saunders, M. J., \& Mercy, E. L. P. (1975). Garnet-peridotite, primary ultrabasic magma and eclogite; Interpretation of upper mantle processes in kimberlite. Physics and Chemistry of the Earth, 9, 571-604. https://doi.org/10.1016/0079-1946(75)90040-3

O'Neill, H. S. C., \& Palme, H. (2008). Collisional erosion and the non-chondritic composition of the terrestrial planets. Philosophical Transactions of the Royal Society A: Mathematical, Physical and Engineering Sciences, 366(1883), 4205-38. https://doi.org/10.1098/ rsta.2008.0111

Palme, H., \& O'Neill, H. (2003). Cosmochemical estimates of mantle composition. In Treatise on geochemistry (Vol. 1, pp. 1-38). Elsevier. https://doi.org/10.1016/B978-0-08-095975-7.00201-1

Plank, T., \& Langmuir, C. H. (1992). Effects of the melting regime on the composition of the oceanic crust. Journal of Geophysical Research, 97(B13), 19,749-19,770. https://doi.org/10.1029/92jb01769

Rhodes, J. M., \& Dawson, J. B. (1975). Major and trace element chemistry of peridotite inclusions from the Lashaine volcano, Tanzania. Physics and Chemistry of the Earth, 9(C), 545-557. https://doi.org/10.1016/0079-1946(75)90038-5

Ringwood, A. E. (1975). Composition and petrology of the Earth's mantle (p. 618). New York: MacGraw-Hill.

Saal, A. E., Kurz, M. D., Hart, S. R., Blusztajn, J. S., Blichert-Toft, J., Liang, Y., \& Geist, D. J.(2007). The role of lithospheric gabbros on the composition of Galapagos lavas. Earth and Planetary Science Letters, 257(3-4), 391-406. https://doi.org/10.1016/j.epsl.2007.02.040

Saal, A. E., \& Van Orman, J. A. (2004). The 226Ra enrichment in oceanic basalts: Evidence for melt-cumulate diffusive interaction processes within the oceanic lithosphere. Geochemistry, Geophysics, Geosystems, 5, Q02008. https://doi.org/10.1029/2003GC000620

Salters, V. J., \& Hart, S. R. (1989). The hafnium paradox and the role of garnet in the source of mid-ocean-ridge basalts. Nature, 342(6248), 420-422. https://doi.org/10.1038/342420a0

Salters, V. J. M., \& Longhi, J. (1999). Trace element partitioning during the initial stages of melting beneath mid-ocean ridges. Earth and Planetary Science Letters, 166(1-2), 15-30. https://doi.org/10.1016/S0012-821X(98)00271-4

Scott, S. R., Ramos, F. C., \& Gill, J. B. (2018). Spreading dynamics of an intermediate ridge: Insights from U-series disequilibria, Endeavour segment, Juan de Fuca Ridge. Journal of Petrology, 59, 1-22. https://doi.org/10.1093/petrology/egy082

Shaw, D. M. (2000). Continuous (dynamic) melting theory revisited. Canadian Mineralogist, 38(5), 1041-1063. https://doi.org/10.2113/ gscanmin.38.5.1041

Sims, K. W. W., Blichert-Toft, J., Fornari, D. J., Perfit, M. R., Goldstein, S. J., Johnson, P., et al. (2003). Aberrant youth: Chemical and isotopic constraints on the origin of off-axis lavas from the East Pacific Rise, $9-10^{\circ}$ N. Geochemistry, Geophysics, Geosystems, $4(10), 8621$. https://doi.org/10.1029/2002GC000443

Sims, K. W. W. S., Oldstein, S. J. G., Toft, J. B. L., Erfit, M. R. P., Elemen, P. K., Ornari, D. J. F., \& Ichael, P. M. (2002). Chemical and isotopic constraints on the generation and transport of magma beneath the East Pacific Rise. Geochimica et Cosmochimica Acta, 66(19), 3481-3504. https://doi.org/10.1016/S0016-7037(02)00909-2

Spiegelman, M., \& Elliott, T. (1993). Consequences of melt transport for uranium series disequilibrium in young lavas. Earth and Planetary Science Letters, 118(1-4), 1-20. https://doi.org/10.1016/0012-821X(93)90155-3

Spiegelman, M., \& Kelemen, P. B. (2003). Extreme chemical variability as a consequence of channelized melt transport. Geochemistry, Geophysics, Geosystems, 4(7), 1055. https://doi.org/10.1029/2002GC000336

Stracke, A., Salters, V. J. M., \& Sims, K. W. W. (2000). Assessing the presence of garnet-pyroxenite in the mantle sources of basalts through combined hafnium-neodymium-thorium isotope systematics. Geochemistry, Geophysics, Geosystems, 1(12), 1006. https://doi.org/ 10.1029/1999GC000013

Sun, C., Graff, M., \& Liang, Y. (2017). Trace element partitioning between plagioclase and silicate melt: The importance of temperature and plagioclase composition, with implications for terrestrial and lunar magmatism. Geochimica et Cosmochimica Acta, 206, $273-295$. https://doi.org/10.1016/j.gca.2017.03.003

Taylor, S. R., \& McLennan, S. M. (1985). The continental crust: Its composition and evolution (p. 328). Blackwell Sci. Publ.

Till, C. B., Grove, T. L., \& Krawczynski, M. J. (2012). A melting model for variably depleted and enriched lherzolite in the plagioclase and spinel stability fields. Journal of Geophysical Research, 117, B06206. https://doi.org/10.1029/2011JB009044

Turner, S., Blundy, J., Wood, B., \& Hole, M. (2000). Large ${ }^{230}$ Th-excesses in basalts produced by partial melting of spinel lherzolite. Chemical Geology, 162(2), 127-136. https://doi.org/10.1016/S0009-2541(99)00127-8

Van Orman, J. A., \& Saal, A. E. (2009). Influence of crustal cumulates on ${ }^{210} \mathrm{~Pb}$ disequilibria in basalts. Earth and Planetary Science Letters, 284(3-4), 284-291. https://doi.org/10.1016/j.epsl.2009.04.034

Van Orman, J. A., Saal, A. E., Bourdon, B., \& Hauri, E. H. (2006). Diffusive fractionation of U-series radionuclides during mantle melting and shallow-level melt-cumulate interaction. Geochimica et Cosmochimica Acta, 70(18), 4797-4812. https://doi.org/10.1016/j. gca.2006.07.005

van Westrenen, W., Blundy, J., \& Wood, B. (1999). Crystal-chemical controls on trace element partitioning between garnet and anhydrous silicate melt. American Mineralogist, 84(5-6), 838-847. https://doi.org/10.2138/am-1999-5-617

van Westrenen, W., Blundy, J. D., \& Wood, B. J. (2001). High field strength element/rare earth element fractionation during partial melting in the presence of garnet: Implications for identification of mantle heterogeneities. Geochemistry, Geophysics, Geosystems, 2(7), 1039. https://doi.org/10.1029/2000GC000133

Volpe, A. M., Golixtein, S. J., \& Goldstein, S. J. (1993). ${ }^{226} \mathrm{Ra}^{-230}$ Th disequilibrium in axial and off-axis mid-ocean ridge basalts. Geochimica et Cosmochimica Acta, 57(6), 1233-1241. https://doi.org/10.1016/0016-7037(93)90060-A 
Walter, M. J. (1998). Melting of garnet peridotite and the origin of komatiite and depleted lithosphere. Journal of Petrology, 39(1), 29-60. https://doi.org/10.1093/petroj/39.1.29

Waters, C. L., Sims, K. W. W., Perfit, M. R., Blichert-Toft, J., \& Blusztajn, J. (2011). Perspective on the genesis of E-MORB from chemical and isotopic heterogeneity at $9-10^{\circ}$ East Pacific Rise. Journal of Petrology, 52(3), 565-602. https://doi.org/10.1093/petrology/egq091

Waters, C. L., Soule, S. A., \& Plank, T. (2013). Recent volcanic accretion at $9^{\circ} \mathrm{N}-10^{\circ} \mathrm{N}$ East Pacific Rise as resolved by combined geochemical and geological observations. Geochemistry, Geophysics, Geosystems, 14, 2547-2574. https://doi.org/10.1002/ggge.20134

Weatherley, S. M., \& Katz, R. F. (2012). Melting and channelized magmatic flow in chemically heterogeneous, upwelling mantle. Geochemistry, Geophysics, Geosystems, 13, Q0AC18. https://doi.org/10.1029/2011GC003989

Weatherley, S. M., \& Katz, R. F. (2016). Melt transport rates in heterogeneous mantle beneath mid-ocean ridges. Geochimica et Cosmochimica Acta, 172, 39-54. https://doi.org/10.1016/j.gca.2015.09.029

White, W. M., \& Klein, E. M. (2014). Composition of the oceanic crust. In Treatise on geochemistry(2nd ed., pp. 457-496). Elsevier. https:// doi.org/10.1016/B978-0-08-095975-7.00315-6

Wood, B. J., Blundy, J. D., \& Robinson, J. A. C. (1999). The role of clinopyroxene in generating U-series disequilibrium during mantle melting. Geochimica et Cosmochimica Acta, 63(10), 1613-1620. https://doi.org/10.1016/S0016-7037(98)00302-0

Workman, R. K., \& Hart, S. R. (2005). Major and trace element composition of the depleted MORB mantle (DMM ). Earth and Planetary Science Letters, 231, 53-72. https://doi.org/10.1016/j.epsl.2004.12.005

Yang, H.-J., Kinzler, R. J., \& Grove, T. L. (1996). Experiments and models of anhydrous, basaltic olivine-plagioclase-augite saturated melts from 0.001 to $10 \mathrm{kbar}$. Contributions to Mineralogy and Petrology, 124(1), 1-18. https://doi.org/10.1007/s004100050169

Zhu, W., Gaetani, G. A., Fusseis, F., Montési, L. G. J., \& De Carlo, F. (2011). Microtomography of partially molten rocks: Three-dimensional melt distribution in mantle peridotite. Science, 332(6025), 88-91. https://doi.org/10.1126/science.1202221

Zou, H., \& Reid, M. R. (2001). Quantitative modeling of trace element fractionation during incongruent dynamic melting. Geochimica et Cosmochimica Acta, 65(1), 153-162. https://doi.org/10.1016/S0016-7037(00)00505-6

\section{References From the Supporting Information}

Adam, J., \& Green, T. (2006). Trace element partitioning between mica- and amphibole-bearing garnet lherzolite and hydrous basanitic melt: 1. Experimental results and the investigation of controls on partitioning behaviour. Contributions to Mineralogy and Petrology, 152(1), 1-17. https://doi.org/10.1007/s00410-006-0085-4

Aigner-Torres, M., Blundy, J., Ulmer, P., \& Pettke, T. (2007). Laser ablation ICPMs study of trace element partitioning between plagioclase and basaltic melts: An experimental approach. Contributions to Mineralogy and Petrology, 153(6), 647-667. https://doi.org/10.1007/ s00410-006-0168-2

Bindeman, I. N., \& Davis, A. M. (2000). Trace element partitioning between plagioclase and melt: Investigation of dopant influence on partition behavior. Geochimica et Cosmochimica Acta, 64(16), 2863-2878. https://doi.org/10.1016/S0016-7037(00)00389-6

DePaolo, D. J. (1981). Trace element and isotopic effects of combined wallrock assimilation and fractional crystallization. Earth and Planetary Science Letters, 53, 189-202.

Fonseca, R. O. C., Mallmann, G., Sprung, P., Sommer, J. E., Heuser, A., Speelmanns, I. M., \& Blanchard, H. (2014). Redox controls on tungsten and uranium crystal/silicate melt partitioning and implications for the U/W and Th/W ratio of the lunar mantle. Earth and Planetary Science Letters, 404, 1-13. https://doi.org/10.1016/j.epsl.2014.07.015

Gaetani, G. A., Kent, A. J. R., Grove, T. L., Hutcheon, I. D., \& Stolper, E. M. (2003). Mineral/melt partitioning of trace elements during hydrous peridotite partial melting. Contributions to Mineralogy and Petrology, 145(4), 391-405. https://doi.org/10.1007/s00410$003-0447-0$

Grove, T. L. (1993). Corrections to expressions for calculating mineral components in "Origin of calc-alkaline series lavas at medicine lake volcano by fractionation, assimilation and mixing" and "Experimental petrology of normal MORB near the Kane Fracture Zone: $22^{\circ}-25^{\circ}$ N, mid-Atlantic ridge". Contributions to Mineralogy and Petrology, 114(3), 422-424. https://doi.org/10.1007/BF01046543

Hart, S. R., \& Dunn, T. (1993). Experimental cpx/melt partitioning of 24 trace elements. Contributions to Mineralogy and Petrology, 113(1), 1-8. https://doi.org/10.1007/BF00320827

Hauri, E. H., Wagner, T. P., \& Grove, T. L. (1994). Experimental and natural partitioning of Th, U, Pb and other trace elements between garnet, clinopyroxene and basaltic melts. Chemical Geology, 117(1-4), 149-166. https://doi.org/10.1016/0009-2541(94)90126-0

Hill, E., Blundy, J. D., \& Wood, B. J. (2011). Clinopyroxene melt trace element partitioning and the development of a predictive model for HFSE and Sc. Contributions to Mineralogy and Petrology, 161(3), 423-438. https://doi.org/10.1007/s00410-010-0540-0

Horn, I., Foley, S. F., Jackson, S. E., \& Jenner, G. A. (1994). Experimentally determined partitioning of high-field strength-elements and selected transition-elements between spinel and basaltic melt. Chemical Geology, 117(1-4), 193-218.

Irving, A. J., \& Frey, F. A. (1978). Distribution of trace elements between garnet megacrysts and host volcanic liquids of kimberlitic to rhyolitic composition. Geochimica et Cosmochimica Acta, 42(6), 771-787. https://doi.org/10.1016/0016-7037(78)90092-3

Kelemen, P. B., Hirth, G., Shimizu, N., Spiegelman, M., \& Dick, H. J. B. (1997). A review of melt migration processes in the adiabatically upwelling mantle beneath oceanic spreading ridges. Philosophical Transactions of the Royal Society A: Mathematical, Physical and Engineering Sciences, 355(1723), 283-318. https://doi.org/10.1098/rsta.1997.0010

Kelemen, P. B., Joyce, D. B., Webster, J. D., \& Holloway, J. R. (1990). Reaction between ultramafic rock and fractionating basaltic magma II Experimental investigation of reaction between olivine tholeiite and harzburgite at $1150-1050^{\circ} \mathrm{C}$ and $5 \mathrm{~kb}$. Journal of Petrology, 31 , 99-134.

Kennedy, A. K., Lofgren, G. E., \& Wasserburg, G. J. (1993). An experimental study of trace element partitioning between olivine, orthopyroxene and melt in chondrules: Equilibrium values and kinetic effects. Earth and Planetary Science Letters, 115(1-4), 177-195. https:// doi.org/10.1016/0012-821X(93)90221-T

Klemme, S., Blundy, J. D., \& Wood, B. J. (2002). Experimental constraints on major and trace element partitioning during partial melting of eclogite. Geochimica et Cosmochimica Acta, 66(17), 3109-3123. https://doi.org/10.1016/S0016-7037(02)00859-1

Kushiro, I. (1990). Partial melting of mantle wedge and evolution of island arc crust. Journal of Geophysical Research, 95(B10), 15,929-15,939. https://doi.org/10.1029/JB095iB10p15929

LaTourrette, T. Z., \& Burnett, D. S. (1992). Experimental determination of U and Th partitioning between clinopyroxene and natural and synthetic basaltic liquid. Earth and Planetary Science Letters, 110(1-4), 227-244. https://doi.org/10.1016/0012-821X(92)90050-6

LaTourrette, T. Z., Kennedy, A. K., \& Wasserburg, G. J. (1993). Thorium-uranium fractionation by garnet: Evidence for a deep source and rapid rise of oceanic basalts. Science, 261(5122), 739-42. https://doi.org/10.1126/science.261.5122.739 
Laubier, M., Grove, T. L., \& Langmuir, C. H. (2014). Trace element mineral/melt partitioning for basaltic and basaltic andesitic melts: An experimental and laser ICP-MS study with application to the oxidation state of mantle source regions. Earth and Planetary Science Letters, 392, 265-278. https://doi.org/10.1016/j.epsl.2014.01.053

Lissenberg, C. J., \& Dick, H. J. B. (2008). Melt-rock reaction in the lower oceanic crust and its implications for the genesis of mid-ocean ridge basalt. Earth and Planetary Science Letters, 271(1-4), 311-325. https://doi.org/10.1016/j.epsl.2008.04.023

Longhi, J. (2002). Some phase equilibrium systematics of lherzolite melting: I. Geochemistry, Geophysics, Geosystems, 3(3), 1-33. https://doi. org/10.1029/2001GC000204

Longhi, J., Walker, D., \& Hays, J. F. (1978). The distribution of Fe and Mg between olivine and lunar basaltic liquids. Geochimica et Cosmochimica Acta, 42(10), 1545-1558. https://doi.org/10.1016/0016-7037(78)90025-X

McDade, P., Blundy, J. D., \& Wood, B. J. (2003). Trace element partitioning on the Tinaquillo solidus at 1.5GPa. Physics of the Earth and Planetary Interiors, 139(1-2), 129-147. https://doi.org/10.1016/S0031-9201(03)00149-3

Nagasawa, H., Schreiber, H. D., \& Morris, R. V. (1980). Experimental mineral/liquid partition coefficients of the rare earth elements (REE), Sc and Sr for perovskite, spinel and melilite. Earth and Planetary Science Letters, 46(3), 431-437. https://doi.org/10.1016/0012-821X(80) 90056-4

Parman, S. W., \& Grove, T. L. (2004). Harzburgite melting with and without $\mathrm{H}_{2} \mathrm{O}$ : Experimental data and predictive modeling. Journal of Geophysical Research, 109, B02201. https://doi.org/10.1029/2003JB002566

Righter, K., Leeman, W. P., \& Hervig, R. L. (2006). Partitioning of Ni, Co and V between spinel-structured oxides and silicate melts: Importance of spinel composition. Chemical Geology, 227(1-2), 1-25. https://doi.org/10.1016/j.chemgeo.2005.05.011

Salters, V. J. M., Longhi, J. E., \& Bizimis, M. (2002). Near mantle solidus trace element partitioning at pressures up to 3.4GPa. Geochemistry, Geophysics, Geosystems, 3(7), 1-23. https://doi.org/10.1029/2001GC000148

Shaw, D. M. (2006). Trace elements in magmas: A theoretical treatment. Cambridge, UK: Cambridge University Press.

Suhr, G., Seck, H. A., Shimizu, N., Günther, D., \& Jenner, G. (1998). Infiltration of refractory melts into the lowermost oceanic crust: Evidence from dunite- and gabbro-hosted clinopyroxenes in the Bay of Islands Ophiolite. Contributions to Mineralogy and Petrology, 131(2), 136-154. https://doi.org/10.1007/s004100050384

Sun, C., \& Liang, Y. (2012). Distribution of REE between clinopyroxene and basaltic melt along a mantle adiabat: Effects of major element composition, water, and temperature. Contributions to Mineralogy and Petrology, 163(5), 807-823. https://doi.org/10.1007/s00410-0110700-X

Sun, C., \& Liang, Y. (2013a). Distribution of REE and HFSE between low-Ca pyroxene and lunar picritic melts around multiple saturation points. Geochimica et Cosmochimica Acta, 119, 340-358. https://doi.org/10.1016/j.gca.2013.05.036

Sun, C., \& Liang, Y. (2013b). The importance of crystal chemistry on REE partitioning between mantle minerals (garnet, clinopyroxene, orthopyroxene, and olivine) and basaltic melts. Chemical Geology, 358, 23-36. https://doi.org/10.1016/j.chemgeo.2013.08.045

Tepley, F. J. I., Lundstrom, C. C., Mcdonough, W. F., \& Thompson, A. (2010). Lithos Trace element partitioning between high-An plagioclase and basaltic to basaltic andesite melt at 1 atmosphere pressure. Lithos, 118(1-2), 82-94. https://doi.org/10.1016/j. lithos.2010.04.001

van Kan Parker, M., Liebscher, A., Frei, D., van Sijl, J., van Westrenen, W., Blundy, J., \& Franz, G. (2010). Experimental and computational study of trace element distribution between orthopyroxene and anhydrous silicate melt: Substitution mechanisms and the effect of iron. Contributions to Mineralogy and Petrology, 159(4), 459-473. https://doi.org/10.1007/s00410-009-0435-0

van Westrenen, W., Allan, N. L., Blundy, J. D., Purton, J. A., \& Wood, B. J. (2000). Atomistic simulation of trace element incorporation into garnets-comparison with experimental garnet-melt partitioning data. Geochimica et Cosmochimica Acta, 64(9), 1629-1639. https://doi. org/10.1016/S0016-7037(00)00336-7

Warren, J. M. (2016). Global variations in abyssal peridotite compositions. Lithos, 248-251, 193-219. https://doi.org/10.1016/j.lithos. 2015.12.023

White, W. M. (2013). Chapter 7: Trace elements, Geochemistry. Wiley-Blackwell. https://doi.org/10.3366/jsp.2001.24.3.1

Wijbrans, C. H., Klemme, S., Berndt, J., \& Vollmer, C. (2015). Experimental determination of trace element partition coefficients between spinel and silicate melt: The influence of chemical composition and oxygen fugacity. Contributions to Mineralogy and Petrology, 169(4), 45. https://doi.org/10.1007/s00410-015-1128-5

Wood, B. J., \& Blundy, J. D. (2014). Trace element partitioning: The influences of ionic radius, cation charge, pressure, and temperature. In Treatise on geochemistry (2nd ed., Vol. 3, pp. 421-448). Elsevier. https://doi.org/10.1016/B978-0-08-095975-7.00209-6

Yao, L., Sun, C., \& Liang, Y. (2012). A parameterized model for REE distribution between low-Ca pyroxene and basaltic melts with applications to REE partitioning in low-Ca pyroxene along a mantle adiabat and during pyroxenite-derived melt and peridotite interaction. Contributions to Mineralogy and Petrology, 164(2), 261-280. https://doi.org/10.1007/s00410-012-0737-5 